Technical Evaluation Report

\title{
Design and Implementation of Project-Specific Document and Drawing Database Systems
}

December 1985

Prepared for the U.S. Nuclear Regulatory Commission under Contract DE-AC06-76RLO 1830

NRC FIN B2952

Pacific Northwest Laboratory

Operated for the U.S. Department of Energy

by Battelle Memorial Institute 


\title{
DISCLAIMER
}

This report was prepared as an account of work sponsored by an agency of the United States Government. Neither the United States Government nor any agency thereof, nor any of their employees, makes any warranty, express or implied, or assumes any legal liability or responsibility for the accuracy, completeness, or usefulness of any information, apparatus, product, or process disclosed, or represents that its use would not infringe privately owned rights.

Reference herein to any specific commercial product, process, or service by trade name, trademark, manufacturer, or otherwise, does not necessarily constitute or imply its endorsement, recommendation, or favoring by the United States Government or any agency thereof. The views and opinions of authors expressed herein do not necessarily state or reflect those of the United States Government or any agency thereof.

\author{
PACIFIC NORTHWEST LABORATORY \\ operated by \\ BATTELLE \\ for the \\ UNITED STATES DEPARTMENT OF ENERGY \\ under Contract DE-AC06-76RLO 1830
}


Technical Evaluation Report

\section{DESIGH AND IMPLEMENTATION OF PROJECT-SPECIFIC DOCUMENT AND DRAHING DATABASE SYSTEMS}

Decenber 1985

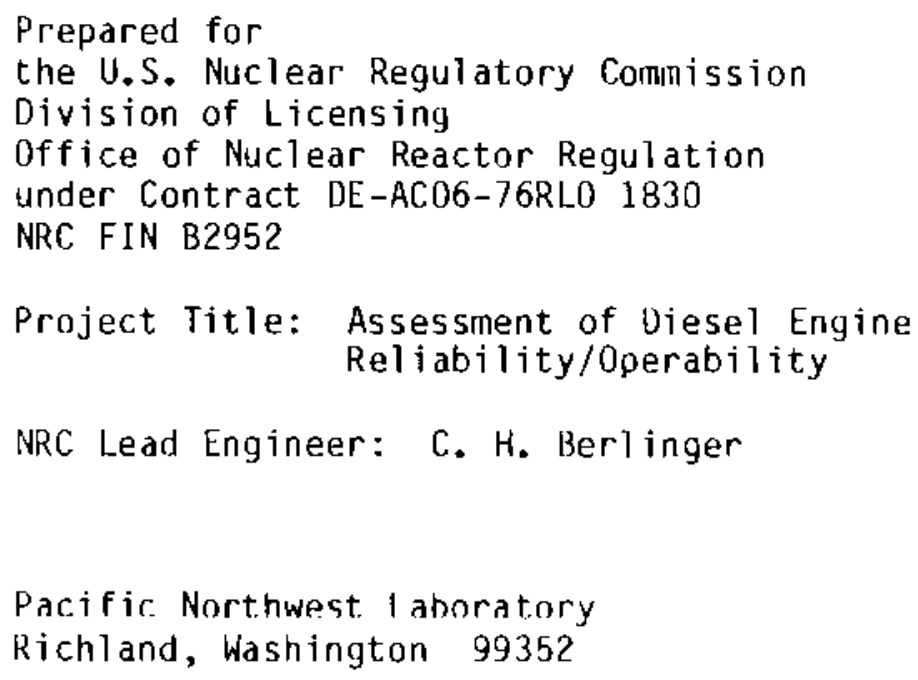



PACIFIC NORTHWEST LABORATORY

PROJECT APPROVALS

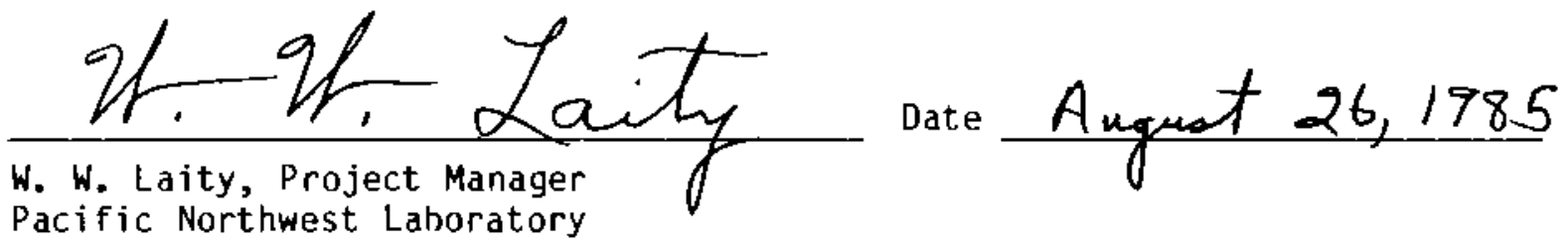

mo Per

Date $q-5-85$

W. D. Richmond, Chairman

Senior Review Panel

Pacific Northwest Laboratory

$i \mathfrak{i}$ 

This report is supplied as part of the Technical Assistance Project, Assessment of Diesel Engine Reliability/Operability, being conducted for the U.S. Nuclear Regulatory Commission, Office of Nuclear Reactor Regulation, Division of Licensing, by the Pacific Nortbwest Laboratory. The U.S. Nuclear Regulatory Commission funded this work under duthorization B\&R 20-19-40-42-1 FIN No. B2952.
This report was written by PNL project team member R. E. Oodge. Document coding and data entry for the document and drawing databases were provided by $S$. R. Freeman, V. L. Heimbigner, R. K. Keatts, R. I. Laidler, and L. J. Schwartz. A. J. Currie edited the report. Word processing and illustration layups were done by $\mathrm{K}$. L. Filsinger. 



\section{CONTENTS}

PACIFIC NORTHWEST LABORATORY PROJECT APPROVALS

FOREWORD

ACKNOWLEDGMENTS

FIGURES

TARLF.S

1.0 INTRODUCTION

2.0 DATABASE SYSTEMS DEVELOPMENT

2.1 HARDWARE AND SOFTWARE SELECTION

2.2 DOCUMENT DATABASE DESIGN

2.3 DRAWING DATABASE DESIGN

3.0 DOCUMENT DATABASE FEATURES

3.1 DATABASE FIELDS

3.2 TYPE CATEGORIZATION

3.3 ISSUE CATEGORIZATION

3.4 FILE NUMBERS

4.0 DOCUMENT DATABASE USER'S INSTRUCTIONS

4.1 BEFORE BEGINNING

4.2 SEARCHING THE DATABASE 
4.2.2 Keyword Search Mode $\ldots \ldots \ldots \ldots \ldots \ldots \ldots \ldots \ldots \ldots \ldots \ldots \ldots \ldots \ldots \ldots \ldots \ldots \ldots \ldots$

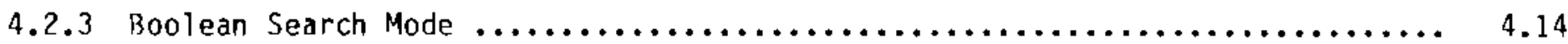

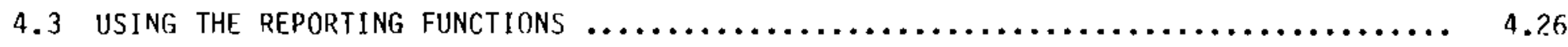

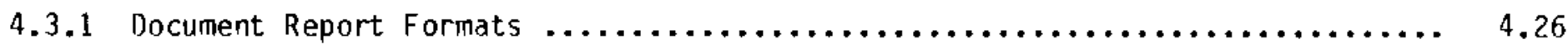

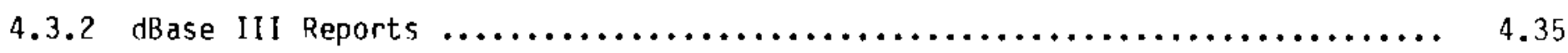

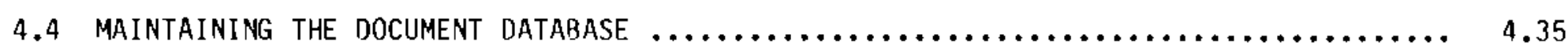

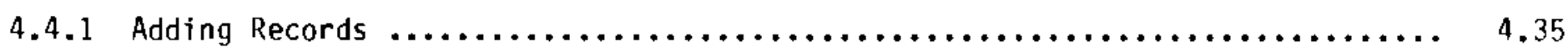

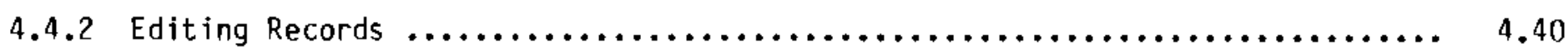

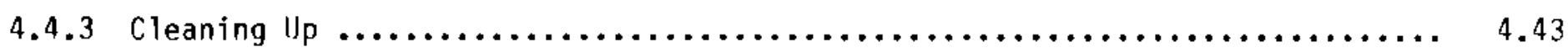

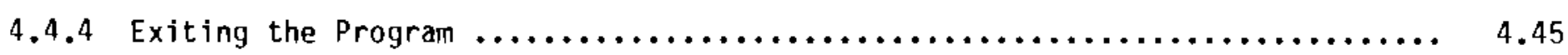

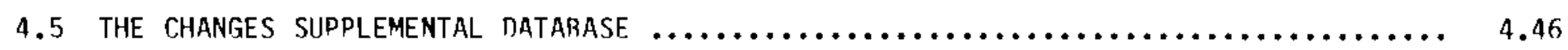

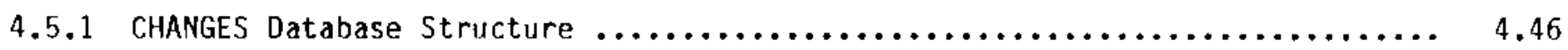

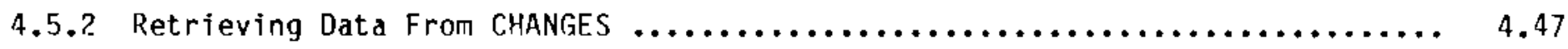

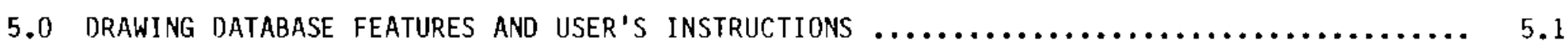

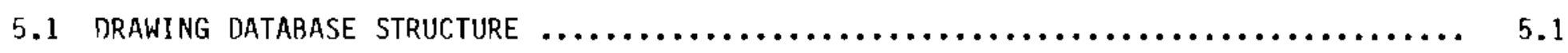

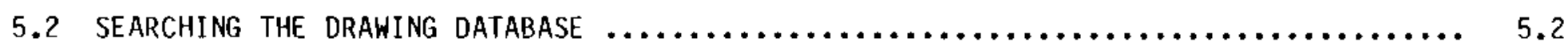

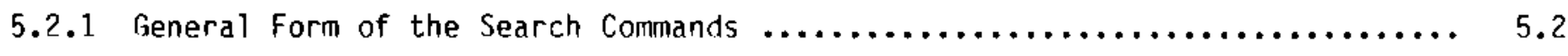

5.2.? Examples of Drawing 0atabase Searches $\ldots \ldots \ldots \ldots \ldots \ldots \ldots \ldots \ldots \ldots \ldots \ldots \ldots . \ldots \ldots$ 
APPENDIX A - DOCUMENT DATABASE MANIPULATIDN PROGRAMS LISTING

APPENDIX B - LIST OF DOCUMENTS IN THE DOCUMENT DATABASE 
4.1 Sample Output Produced by Keyword Search, Sumnary Format Option ....................

4.2 Sample Output Produced by Keyword Search, Expanded Format Option ......................

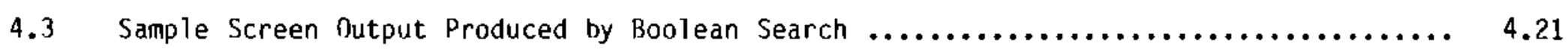

4.4 Sample Printer Output Produced by Boolean Search, Summary Format 0ption .......... 4.24

4.5 Sample Printer Output Produced by Boolean Search, Expanded Format Option ......... 4.25

4.6 First Page of Executive Summary Report for "DATED $>12-31-84 " \ldots \ldots \ldots \ldots \ldots \ldots . \ldots \ldots$

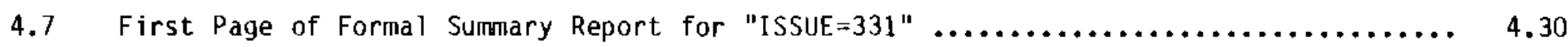

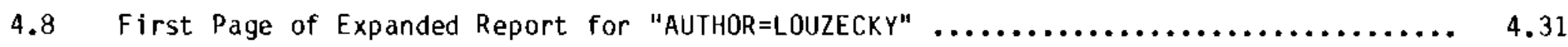

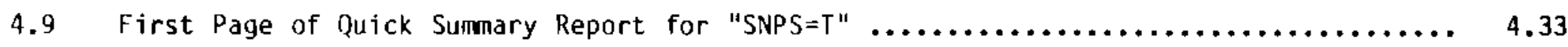

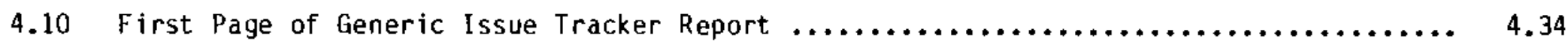

5.1 Sample Output Resulting From "DiSPLAY OFF TITLE,FILE_Num FOR 'FOUnd'\$TITLE" $\ldots \ldots \ldots$

5.2 Sample Output Resulting From "DISPLAY OFF TITLE, FILE_NUM FOR 'PIST'\$TITLE" $\ldots \ldots \ldots$

5.3 Sample Output Resulting from "LIST OFf TITLE,FILE_NUM FOR 'CONN'\$TITLE TO PRINT" .... 5.8

5.4 Sample Output Resulting From "LIST OFF FOR ' 345 ' $\$$ NUMBER TO PRINT" $\ldots \ldots \ldots \ldots \ldots$ 
TARLES

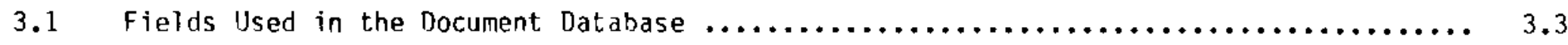

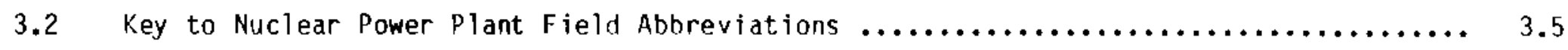

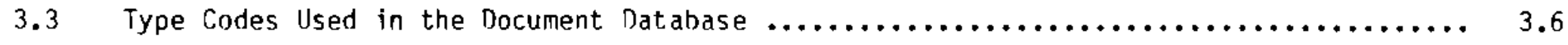

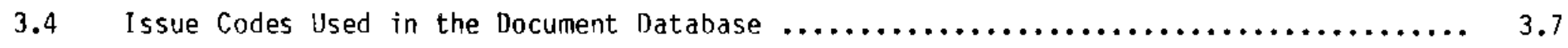

4.1 Computer Files Required to Run the Document Database $\ldots \ldots \ldots \ldots \ldots \ldots \ldots \ldots \ldots$

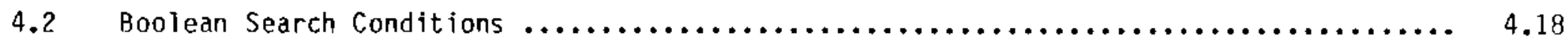

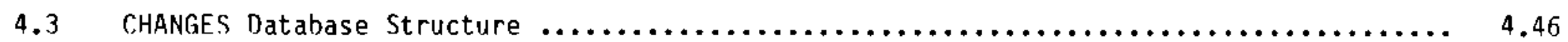

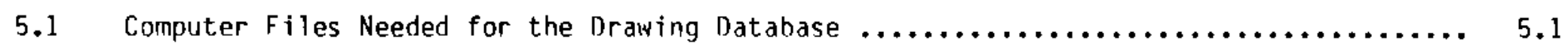

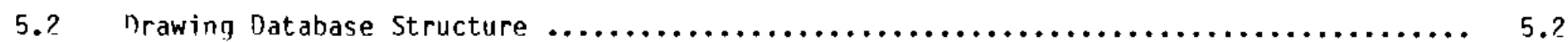

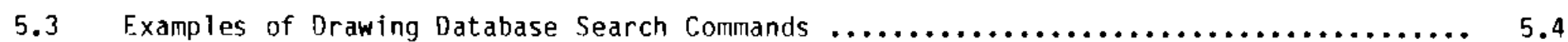




\section{DESIGN AND IMPLEMENTATION}

OF

PROJECT-SPECIFIC DOCUMENT

AND DRAWING DATABASE SYSTEMS

\subsection{INTRODUCTION}

The Pacific Northwest Laboratory (PNL) is supporting the U.S. Nuclear Regulatory Commission (NRC) staff in addressing questions regarding the reliability and operability of Transamerica Delaval, Inc. (TOI) diesel engines used to provide standby power in some nuclear power plants. The objective of PNL's Assessment of Diesel Engine Reliability/0perability (ADERO) project is to provide a technical assessment of information submitted by NRC 1icensees and the TDI Diesel Generator Owners' Group documenting their efforts to establish the acceptability of their TDI diesels for nuclear service.

The AnFRO projert involves multiple parties including NRC, TDI, PNL, the Owners' Group, individual member utilities, suecial interest yroups, and the private consultants to each. Early on, it was recognized that the documentation associated with the actions of, and interactions among, these parties would be voluminous. It was also recognized that these documents should be readily identifiable by cross-referencing, and quickly accessible to all users.

These three factors suggested that a traditional "library" filing system would be inadequate to meet project needs. Instead, a computer-based system was deemed necessary to provide project staff ready access to relevant documents and drawings.

This report describes the computerized document and drawing databases created for the ADERD project. The developmental effort is reviewed in Section 2.0. In Section 3.0, an overview of the document database content, organization, capabilities, and limitations is provided. Section 4.0 comprises the user's manual for the document database, with specific instructions for cataloging and retrieving documents, generating various types of sumnary reports, and maintaining/updating 
the database. Section 5.0 describes the drawing database features and presents user instructions. A complete program listing is contained in Appendix A. Appendix B presents a list of all documents filed in the document database as of September 30 , 1985. The drawings included in the drawing database are similarly listed in Appendix $C$.
The primary purpose of this document is to provide subsequent users with the instructions and other information necessary to interact successfully with the two databases. In addition, the review of system development (Section 2.0) and the program listing (Appendix A) are intended to assist persons involved in developing similar systems. 


\subsection{DATABASE SYSTEMS DEVELOPMENT}

This section reviews the development of the ADERO document and drawing database systems. The primary goal was to develop computerized database systems that would enable rapid selection and retrieval of specific documents and drawings from a large collection. Design objectives were to allow flexible searches on a wide variety of conditions and to provide a logical scheme for manually filing the documents and drawings.

A large number of documents and drawings were on hand immediately subsequent to PNL's initial involvement with the project. Hence, the databases had to be designed "on the fly". They had to be usable almost immediately while remaining modifiable as needs dictated. Uncertainties regarding the duration of the project and the total number of documents to be included also indicated nead for system flexibility.

The following sections describe how the database systems evolved to meet the neerts of the ANRO project.

\subsection{HAROWARE AND SOFTWARE SELECTION}

In deciding which type of documentation control system to implement at the outset of the project, three possibilities were considered:

- a manual system

- a pre-packaged mainframe computerbased system

- a microcomputer-based system using a commercially available database software package.

It was determined that a manual system could neitber effectively handle the large number of documents anticipated for this project, nor provide the desired searching capabilities.

The mainframe computer-based systems considered were the KWIC (for keyword in context) and KWOC (for keyword out of context) systems offered through the Hanford Technical Library. These pre-packaged document cataloguing systems are impleinented on a UNIVAC computer operated by Roeing Computer Services-Richland. Bascd 
Hanford Technical Library, the PNL team decided that both mainframe systems lacked the flexibility and accessibility that could be provided by a microcomputer-based system.

Consequently, temporary access to an IBM-PC with the dBase II software package was obtained. This equipment and software were chosen primarily because of the author's favorable experience with this system configuration.

After work had started on the database design, it became clear that the ADERO project was going to extend beyond FY84. As a result, steps were taken to procure a microcomputer system specifically for project use.

PNL researchers have used dBase II extensively for organizing large sets of related data. The dBase II software simplifies the creation and manipulation of databases, provides a report-generating package, and has a built-in programming language, similar to BASIC, that enables very flexible and specific manipulation and modification of data. However, dBase II requires substantial user training and has some moderate constraints on the size and number of records that can be included in a database.

In 1984 Ashton-Tate released an upgraded version of dBase II referred to as dBase III. The new dBase version greatly increases the size and number of records that may be put into a database, simplifies the programming language, and introduces new functions, commands, and variable types. dBase III also runs faster than dBase II. In addition, dBase III comes with a utility to convert dBase II databases and programs to dBase III files, so the work done already on the project databases could be converted easily to dBase III. After reviewing these features, PNL project staff determined that dBase III would be the more effective software for meeting ADERO project needs.

Meanwhile, the document database was growing as new documents were received. The database was rapidly approaching the maximum size that could be handled with a floppy disk drive system. It was therefore 
determined that a hard disk drive would be required.

The final system configuration selected for this project consists of an IBM-PC, a Tallgrass 12.5-MByte hard disk, an IDS P-132 dot matrix printer, and the dBase III software package. This computer/hard disk/ printer system configuration is used at PNL for similar applications and has been found to function very well.

\subsection{DOCUMENT DATABASE DESIGN}

Designing a database consists of selecting the types of information to record and defining the format for these items in the database. This requires anticipating the future uses of the database. It was decided to design the document database to enable document searches based on a wide variety of information.

Some of the data items (fields) that were included in the document database are described briefly below. All of the document database fields are described in detail in Section 3.1 .
Basic information about each document, such as title, date, author, to whom it was written, and number of pages, is included in the database. In addition, each document is coded according to type. For example, PNL technical reviews are coded as "03" while letters of transmittal are coded as "20". The specific issue addressed by each document is coded separately as well.

A convenient filing system was then devised by assigning a file number beginning with the document type code concatenated to the issue code. As a result, all documents on a given issue are filed together and, within each issue, similar documents are filed together. This system often allowed PNL staff to find desired documents easily by accessing the hard copy files directly. Fields showing the nuclear power plant sites to which each document applied were also incorporated.

Data format can also impact the ease of use of the datatiase. Examples of specific formatting decisions in the ADERO databases are: 
- all entries are in capital letters only

- names are presented last name first

- dates are entered in the standard format mm-dd-yy with zeros used as pilace holders.

As mentioned earlier, the document database evolved as the project progressed. Some of the features just described were not included in the original database design but were added later to improve the system's ability to meet staff needs.

\subsection{DRAWING DATABASE DESIGN}

A second database was developed to accommodate the TDI diesel engine component drawings and purchase specifications provided to NRC and PNL by the Owners' Group. The cover letter (March 23, 1984) accompanying the 1877-item package transmitted to PNL requested that the drawings be accorded proprietary status pursuant to the Rules of Practice, 10 CFR 2.790.

A relatively comprehensive structure was initially envisioned for the DGDRAW database. This structure included fields to specify component function and the engine systern to which the component applied. The original database was designed to also readily accept new drawings, with fields to specify the date of receipt and the sender of the drawing. However, it was determined that the demand for this level of sophistication was insufficient to warrant the level of effort required for its development.

As designed, the DGORAH database contains the drawing title and number, with a PNL-assigned file number for each drawing. Each drawing hard copy is marked with its appropriate file number and filed numerically according to this file number. 


\subsection{DOCUMENT DATABASE FEATURES}

Every document received or generated by $\mathrm{PNL}$ in conjunction with the ADERO project is logged into the document database. This section describes how the documents are catalogued and filed, using the software and programs mentioned in Section 2.0 . This section provides background information necessary to use the database. Detailed user instructions are provided in Section 4.0 .

Before proceeding, a few simple terms that refer to the basic elements of any database must be understood. The relevant terims are FIELD, RECORD, and DATABASE.

A FIELD is a specific data item that will be recorded in the database. For example, in the document database the author of each document is recorded, so AUTHOR is one field. Other examples of fields are the document publication date, the document titic, and the number of pages in the docurnent.

The collection of fields for a single iton in thic raco a dorument! is termed a
RECORD. Thus, data for each document in the database are recorded in a collection of fields that make up a record.

A DATABASE consists of the entire assemblage of records.

In conventional databases, the fields comprising a record must be defined very specifically. In dBase III each field is given a name (e.g., TITLE, DATE, AUTHOR), a length indicating the number of characters in the field, and a data type. The data types allowed in dBase III are character, numeric, logical, date, and memo. The latter two data types are not used in either ADERO database. Character fields may contain any alpha-numeric characters, numeric fields may contain only numbers, and logical fields may take on only one of two values--true or false.

The FIELDS that comprise the RECORD for each document are detailed in Section 3.1. Sections 3.2 and 3.3 describe how project documents are categorized by specific type and topic, respectively. Section 3.4 explains how a file number is xasimnat to ourt dermmont 


\subsection{DATABASE FIFLDS}

The fields that make up the records in the document database are listed and defined in Table 3.1 The site abbreviations (fields SNPS through MP) used in Table 3.1 are explained in Table 3.2.

The fields listed in Table 3.1 represent the basic targets for performing searches. Types of searches possible with the document database system include:

- a speed search mode for use when specific information about a document (e.g., author, date, file number, or title) is known

- a keyword search mode for use when information on specific topics is desired

- a Boolean search mode for more complex searches involving multiple fields.

Several of the fields (DOC TYP, ISSUE, and FILE_NUM) allow functional searches as well. These fields are described.more fully in the next three subsections.

\subsection{TYPE CATEGORIZATION}

Al1 documents are functionally categorized using a two-digit code in the DOC TYP field. The DOC_TYP codes and their significance are listed in Table 3.3.

These categories are designed to be sufficiently general so that each document will fit logically into some category. However, personal discretion was sometimes necessary to determine exactly which category best fit a given document.

\subsection{ISSUE CATEGORIZATION}

Similar to the functional coding employed in 00C_TYP, coding according to the specific issue addressed by the document was also incorporated into the database. The ISSUE codes used in the document database are listed in Table 3.4. Initially these codes were based on the 1 ist of components identified by the Owners' Group as having problems with potential generic applicability. This initial code list was subsequently expanded 
TABLE 3.1. Fields Used in the Document Database

\begin{tabular}{|c|c|c|c|}
\hline Field & Description & Type & Length \\
\hline TITLE & $\begin{array}{l}\text { The document title. If no explicit title, then } \\
\text { one is derived from other information available } \\
\text { on the document. }\end{array}$ & Character & 100 \\
\hline AUTHOR & $\begin{array}{l}\text { The name of the document originator: last name, } \\
\text { first name or initials }\end{array}$ & Character & 50 \\
\hline ORG & $\begin{array}{l}\text { The company or organization with whom the document } \\
\text { author is associated }\end{array}$ & Character & 4 \\
\hline DATED & The date (mm-dd-yy) on the document & Character & 8 \\
\hline To & $\begin{array}{l}\text { The name of the person to whom the document was } \\
\text { written: last name, first name or initials }\end{array}$ & Character & 50 \\
\hline T0_0RG & $\begin{array}{l}\text { The company or organization with whon the docu- } \\
\text { ment recipient is associated }\end{array}$ & Character & 4 \\
\hline SOURCE & $\begin{array}{l}\text { The organization from which PNL received the } \\
\text { document }\end{array}$ & Character & 3 \\
\hline VEND_NUM & $\begin{array}{l}\text { The document number (if any) used by the } \\
\text { organization originating the document }\end{array}$ & Character & 15 \\
\hline DOC_TYP & $\begin{array}{l}\text { A two-digit numerical code that categorizes } \\
\text { the document according to its function (see } \\
\text { Section } 3.2 \text { ) }\end{array}$ & Numeric & 2 \\
\hline ISSUE & $\begin{array}{l}\text { A three-digit code that categorizes the } \\
\text { document according to the topic or issue it } \\
\text { addresses (see Section } 3.3 \text { ) }\end{array}$ & Character & 3 \\
\hline
\end{tabular}




\section{TABLE 3.1. (contd)}

\begin{tabular}{|c|c|c|c|}
\hline Field & Description & Type & Length \\
\hline FILF_NUM & $\begin{array}{l}\text { A number used to file the document (based on } \\
\text { DOC_TYP and ISSUE, as described in Section 3.4) }\end{array}$ & Character & 8 \\
\hline DATE_REC & $\begin{array}{l}\text { The date (mm-dd-yy) on which the document was } \\
\text { received at PNI, estimated when not known } \\
\text { exactly }\end{array}$ & Character & 8 \\
\hline DESCRIP & $\begin{array}{l}\text { A brief (less than 255-character) description } \\
\text { of the document }\end{array}$ & Character & 254 \\
\hline PAGES & Number of pages in the document & Character & 5 \\
\hline \multicolumn{4}{|l|}{ SNPS } \\
\hline \multicolumn{4}{|l|}{ GGNS } \\
\hline \multicolumn{4}{|l|}{ CPSES } \\
\hline \multicolumn{4}{|l|}{ SONGS } \\
\hline RBS & Abbreviations for each of the 13 nuclear power & & \\
\hline RSNGS & plants with TDI diesel generators. These fields & & \\
\hline SHNPP & indicate if the document is applicable to the & Logical & 1 \\
\hline CNS & specified power plant site. & & \\
\hline \multicolumn{4}{|l|}{ PNPP } \\
\hline \multicolumn{4}{|l|}{ BNP } \\
\hline \multicolumn{4}{|l|}{ WNP } \\
\hline \multicolumn{4}{|l|}{ VEGP } \\
\hline MP & & & \\
\hline
\end{tabular}


TABLE 3.2. Key to Nuclear Power Plant Field Abbreviations

\begin{tabular}{|c|c|c|}
\hline Field & Power Plant & Owner Utility \\
\hline SNPS & Shoreham Nuclear Power Station & Long Island Lighting Company \\
\hline GGNS & Grand Gulf Nuclear Station & Mississippi Power \& Light \\
\hline CPSES & Comanche Peak Steam Electric Station & Texas Utilities Generating Company \\
\hline SONGS & San Onofre Nuclear Generating Station & Southern California Edison \\
\hline RBS & River Bend Station & Gulf States Utilities \\
\hline RSNGS & Rancho Seco Nuclear Generating Station & Sacramento Municipal Utility District \\
\hline SHNPP & Shearon Harris Nuclear Power Plant & Carolina Power \& Light \\
\hline CNS & Catawba Nuclear Station & Duke Power Company \\
\hline PNPP & Perry Nuclear Power Plant & Cleveland Electric Illuminating \\
\hline BNP & Bellefonte Nuclear Plant & Tennessee Valley Authority \\
\hline WNP & Washington Nuclear Plant & Washington Public Power Supply System \\
\hline VEGP & Vogtle Electric Generating Plant & Georgia Power Company \\
\hline MP & Midland Plant & Consumers Power Company \\
\hline
\end{tabular}


IABLE 3.3. Type Codes Used in the Document Database

\begin{tabular}{|c|c|}
\hline Code & Description \\
\hline 1 & Recovery Program Description \\
\hline 2 & Technical Analysis \\
\hline 3 & Report Evaluation by PNL \\
\hline 4 & Report Evaluation by PNL Reviewer \\
\hline 5 & Technical Specification \\
\hline 6 & Test Description \\
\hline 7 & Inspection of ThI \\
\hline 8 & Journal Article \\
\hline 9 & Engine Inspection \\
\hline 10 & Other Technical \\
\hline 11 & Operational History (Except Marine) \\
\hline 12 & Literature Reference \\
\hline 13 & Meet ing Minutes and Summary \\
\hline 14 & Meeting Handout, Slide and Note \\
\hline 15 & Marine Operational History \\
\hline 16 & 0ther Letter and Memo \\
\hline 17 & Monthly Report \\
\hline 18 & Personnel Qualification \\
\hline 19 & Financial/Contractual Document \\
\hline 20 & Letter of Transmittal \\
\hline 21 & Legal and Deposition \\
\hline 22 & Trip Report (Except Engine Inspection) \\
\hline 23 & Design Review and Duality Revalidation Report \\
\hline 24 & NRC Report (e.g., SER) \\
\hline
\end{tabular}


IABLE 3.4. Issue Codes Used in the Document Database

\begin{tabular}{|c|c|}
\hline Code & Description \\
\hline 320 & $\begin{array}{l}\text { Review and Preparation of Owners' Group Progran } \\
\text { Plan Technical Evaluation Report }\end{array}$ \\
\hline 330 & Piston Skirts \\
\hline 331 & Crankshafts \\
\hline 332 & Connecting Rod Bearing Shells \\
\hline 333 & Cylinder Heads \\
\hline 335 & Cylinder Block and Liners \\
\hline 336 & Engine Base and Bearing Caps \\
\hline 337 & Cylinder Head Studs \\
\hline 338 & Push Rods \\
\hline 339 & Rocker Arm Capscrews \\
\hline 340 & Connecting Rods \\
\hline 341 & Wiring and Terminations \\
\hline 342 & Fuel $0 i 1$ Injection Jubing \\
\hline 343 & Turbochargers \\
\hline 344 & Jacket Water Pumps \\
\hline 345 & Air Start Valve Capscrews \\
\hline 350 & Grand Gulf Nuclear Station \\
\hline 351 & Catawba Nuclear Station \\
\hline 352 & Shoreham Nuclear Power Station \\
\hline 353 & Comanche Peak Steam Electric Station \\
\hline 354 & San Onofre Nuclear Generating Station \\
\hline 355 & River Bend Station \\
\hline 356 & Shearon Harris Nuclear Power Plant \\
\hline 357 & Vogtle Electric Generating Plant \\
\hline 358 & Perry Nuclear Power Plant \\
\hline
\end{tabular}


to include plant-specific categorization. Expanding the ISSUE code in this manner improved the filing scheme for the document hard copies as described in Section 3.4.

Many documents could not be categorized according to issue, either because they did not pertain to any of the issues listed or because they covered more than one of the specified issues. In these cases, the issue code was set to "000". Generally, documents that addressed a "generic" component at a specific nuclear station were categorized using the component issue code.

\subsection{FILE NUMBERS}

The file numbers (FILE NUM) are used to file the physical (hard copy) documents. FILE_NUM consists of a four-digit base number followed by a dash and a sequence number. The four-digit base number is derived from the DOC_TYP and ISSUE codes by concatenating the two-digit DOC_TYP code to the last two digits of the
ISSUE code. The sequence number simply provides an identifier to make the FILE NUM unique.

As an example, the Failure Analys is Associates (FaAA) report, Design Review of Connecting Rod Bearing Shells for Transamerica Delaval Enterprise Engines (FaAA-84-3-1), was a technical analysis performed by FaAA. The ISSUE code is 332 (connecting rod bearing shells) and the DOC_TYP code is 2 (technical analysis). Because this report was the second document with these characteristics received by PNL, the sequence number is 2 . Therefore, the FILE NUM for this document is 3202-2.

When FILE NUM is used as the basis for filing the hard copy of each document, all documents related to the same issue and document type are filed together. Hence, all technical analyses on connecting rod bearing shells will be filed together. This feature of the filing system greatly enhances its usability. 
The reader should note that the sequence numbers may not be exactly sequential; that is, there may be gaps between these numbers. These gaps are due to $\mathrm{PNL}^{+} \mathrm{S}$ quality assurance procedures. When duplicate document entries are removed, or when incorrectly coded documents are repaired, the system does not reassign these old file numbers. 



\subsection{DOCUMENT DATABASE USER'S INSTRUCTIONS}

This section provides step-by-step instructions for accessing and using the ADERO document database. You will be given specific guidance on:

- steps necessary before running the database

- searching the database

- using the reporting functions

- maintaining and adding to the database

- recovering from unexpected loss of data.

The instructions are illustrated with samples of screen displays and hard copy output.

\subsection{BEFORE BEGINNING}

The following components must be assembled and initiated properly prior to beginning interaction with the database:

- IBM-PC (or equivalent), inciuding a monitor, 512-K RAM, and at least one flopipy alsk drive
- hard disk drive

- printer.

The dBase III programs, ADERO databases, and related programs should reside on the same directory of the hard disk. The dBase III master disk must be in the floppy disk drive whenever the dBase program is started.

The computer files that should be on the hard disk are listed in Table 4.1. Standard dBase conventions for naming the ADERO files have been followed. Database files have been named with an extension (1ast three characters) of "DBF". Similarly, index files that modify the logical ordering of the records within the database have been given the extension "NDX". The program files that contain the source coding are given the extension "PRG". Files that control the format of the record displayed on the screen are given the extension "FMT", and files created with the dBase III report-generating utility are given the extension "FRM". 
TABLF 4.1. Computer Files Needed to Run the Document Database

\begin{tabular}{|c|c|}
\hline $\begin{array}{l}\text { dBase III and } \\
\text { System Files }\end{array}$ & $\begin{array}{c}\text { Document } \\
\text { Database Files }\end{array}$ \\
\hline DBASE.EXE & $D G . D B F$ \\
\hline DBASE.0VL & CHANGES.DBF \\
\hline CONFIG.SYS & ISSUE.DBF \\
\hline \multirow[t]{11}{*}{ CONFIG.DB } & AUTHOR . NDX \\
\hline & DATE.NDX \\
\hline & FILE.NDX \\
\hline & TITLE.NDX \\
\hline & DGPROC.PRG \\
\hline & $D G . P R G$ \\
\hline & DGSTO.FMT \\
\hline & DGTHR.FMT \\
\hline & DGFOR.FMT \\
\hline & TDDF.FRM \\
\hline & EXPRT.FRM \\
\hline
\end{tabular}

With these components properly assembled, enter the hard disk drive designator followed by a colon. This entry will usually be $C:$, $D:$, or $E:$. If the database is in a subdirectory other than the current default directory, then you must change directories (i.e., CD\DBIII\ADERO).

The dBase and ADERO files should now be listed when you type DIR. The document database system is now ready to be used.

In the user instructions that follow, the commands you are to enter appear on the left-hand side of the page, along with explanatory notes. Keyboard entries are enclosed in square brackets; a second right-hand bracket is used to indicate a carriage return. The resulting computer screen contents are portrayed on the righthand side of the page, to illustrate what happens when each cormand is entered.

To begin, proceed as described on the following page. 
Enter: [DBASE DG]]

E) DEASE DC

After a few seconds (and a brief caveat from Ashton-Tate) the Main Menu will be displayed on the screen.
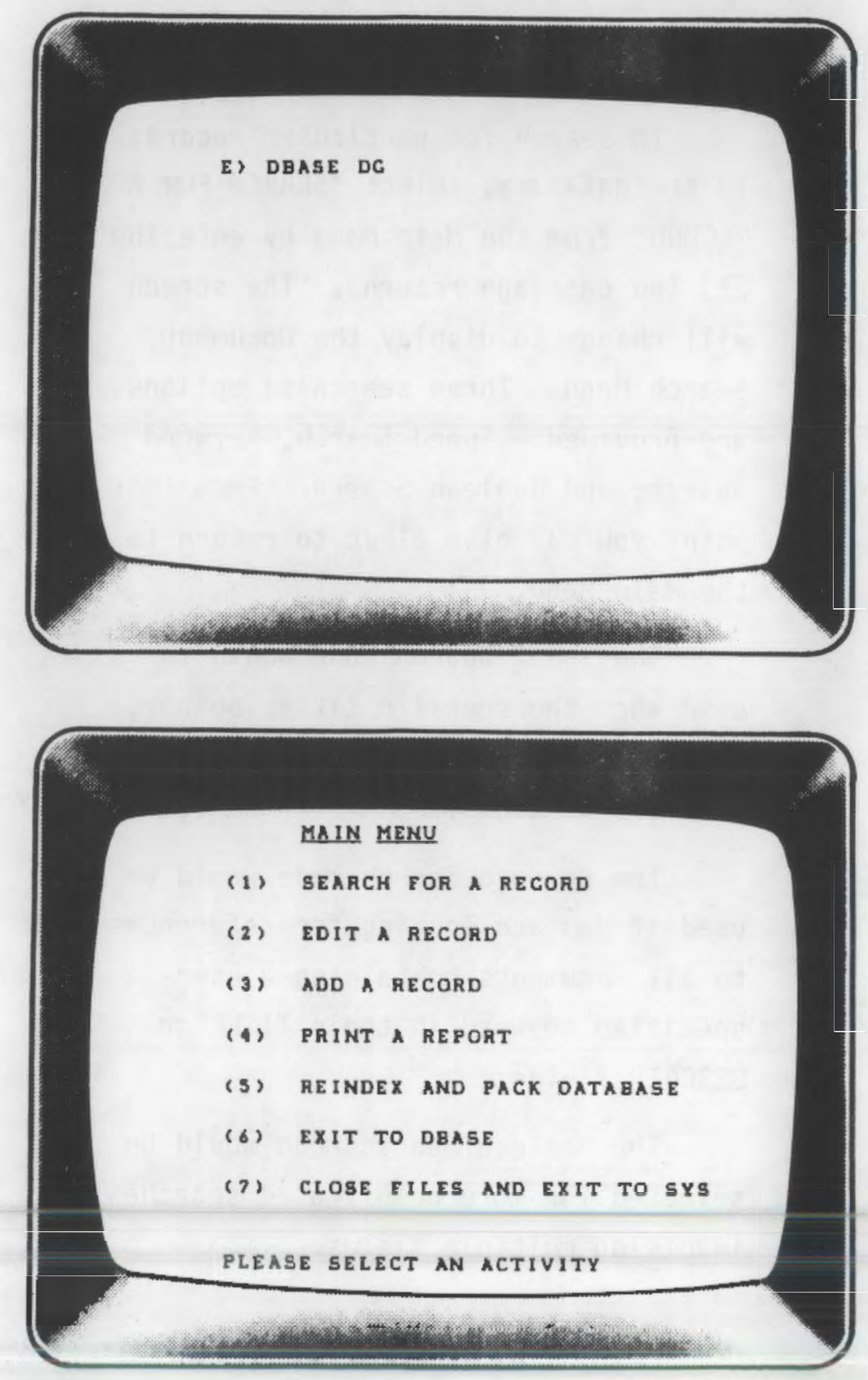

4.3 


\subsection{SEARCHING THE DATABASE}

To search for particular records in the database, select "SEARCH FOR A RECORD" from the Main Menu by entering [1] (no carriage return). The screen will change to display the Document Search Menu. Three searching options are provided: Speed Search, Keyword Search, and Boolean Search. From this point you may also elect to return to the Main Menu.

The Speed Search mode would be used when the specific title, author, date, or file number of a desired document is known.

The Keyword Search mode would be used if you are looking for references to all documents containing a userspecified keyword in their TITLE or DESCRIP fields.

The Boolean Search mode would be selected for more complicated searches involving multiple fields.

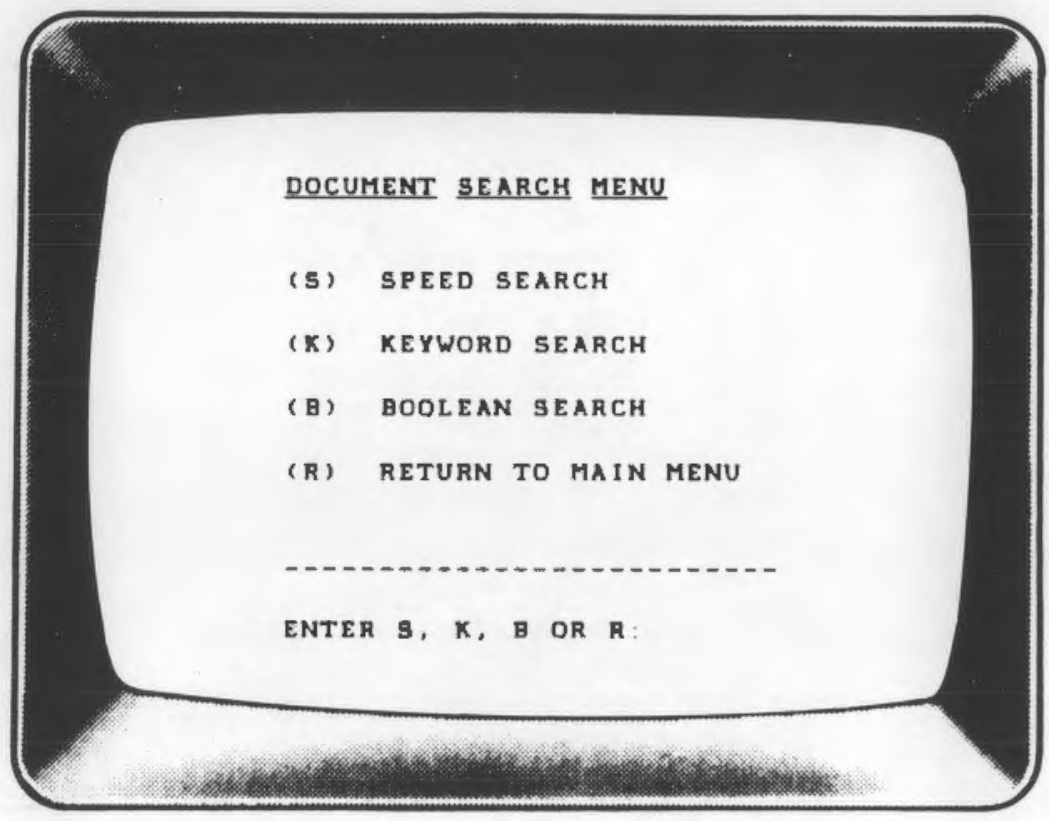

(5) SPEED SEARCH

RETURN TO MAIN MENU 


\subsubsection{Speed Search Mode}

To use the Speed Search mode, enter the letter [S] from the Document Search Menu. The system will respond by displaying the Speed Search options--Title, Author, Date, and File Number--and requesting your selection.

All four options function in exactly the same way. As an example, enter [F] for File Number. You will now be requested to enter a character string. At this point, enter the file number [5010-1]] (followed by a carriage return).
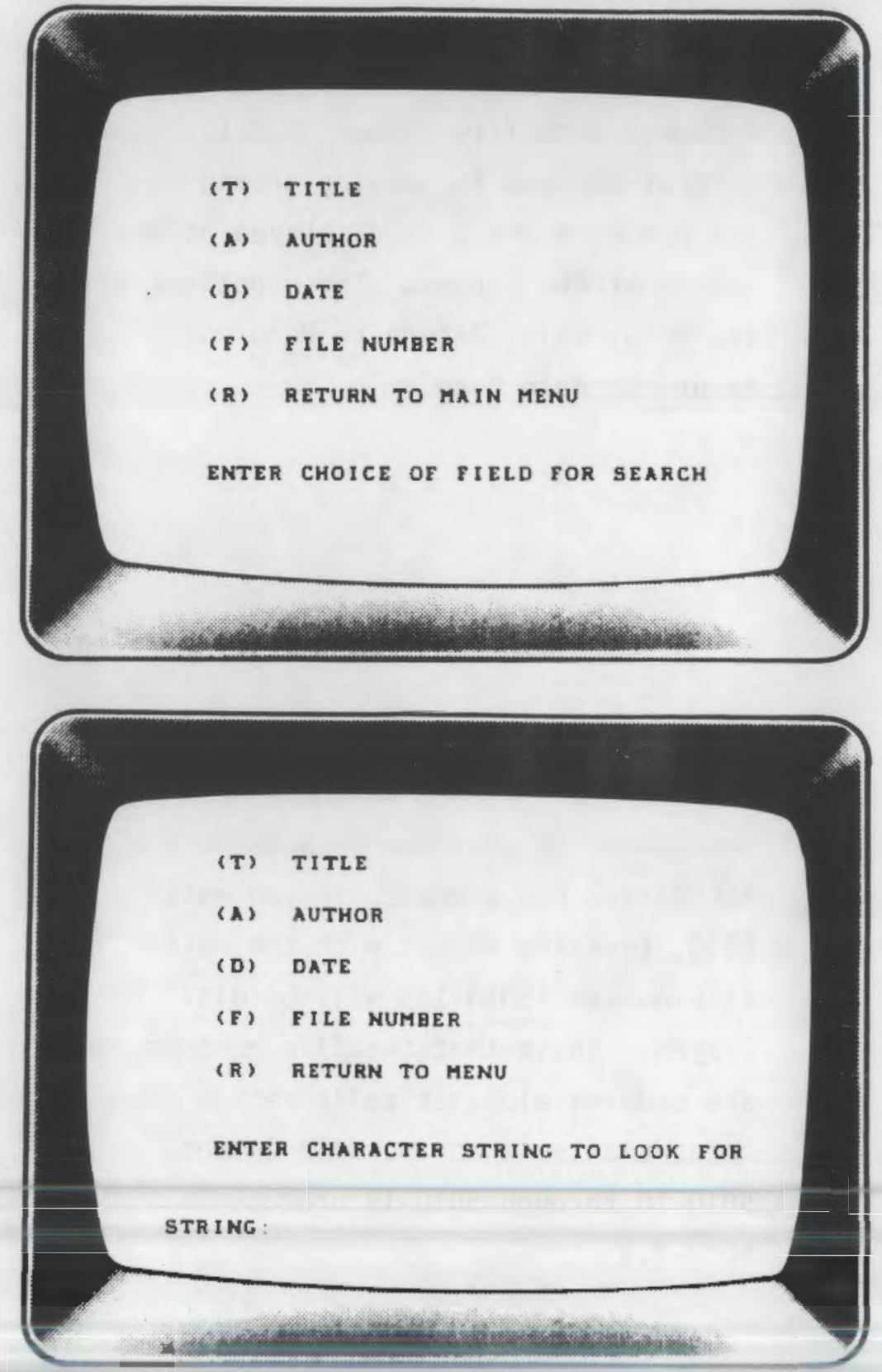
Displayed on the screen now will be the information pertaining to the document with file number 5010-1. Several options for moving around in the database are also displayed at the bottom of the screen. These options are Skip, Edit, Return to Menu and Return to Main Menu.

The Skip option will allow you to look at the information contained in subsequent or previous records in the database. For example, if you enter $[S]]$, then the record with the next file number (5010-10) will be displayed. (Note that the file numbers are ordered alphabetically rather than sequentially; that is, file numbers 5010-10 through 5010-19 precede 5010-2.)
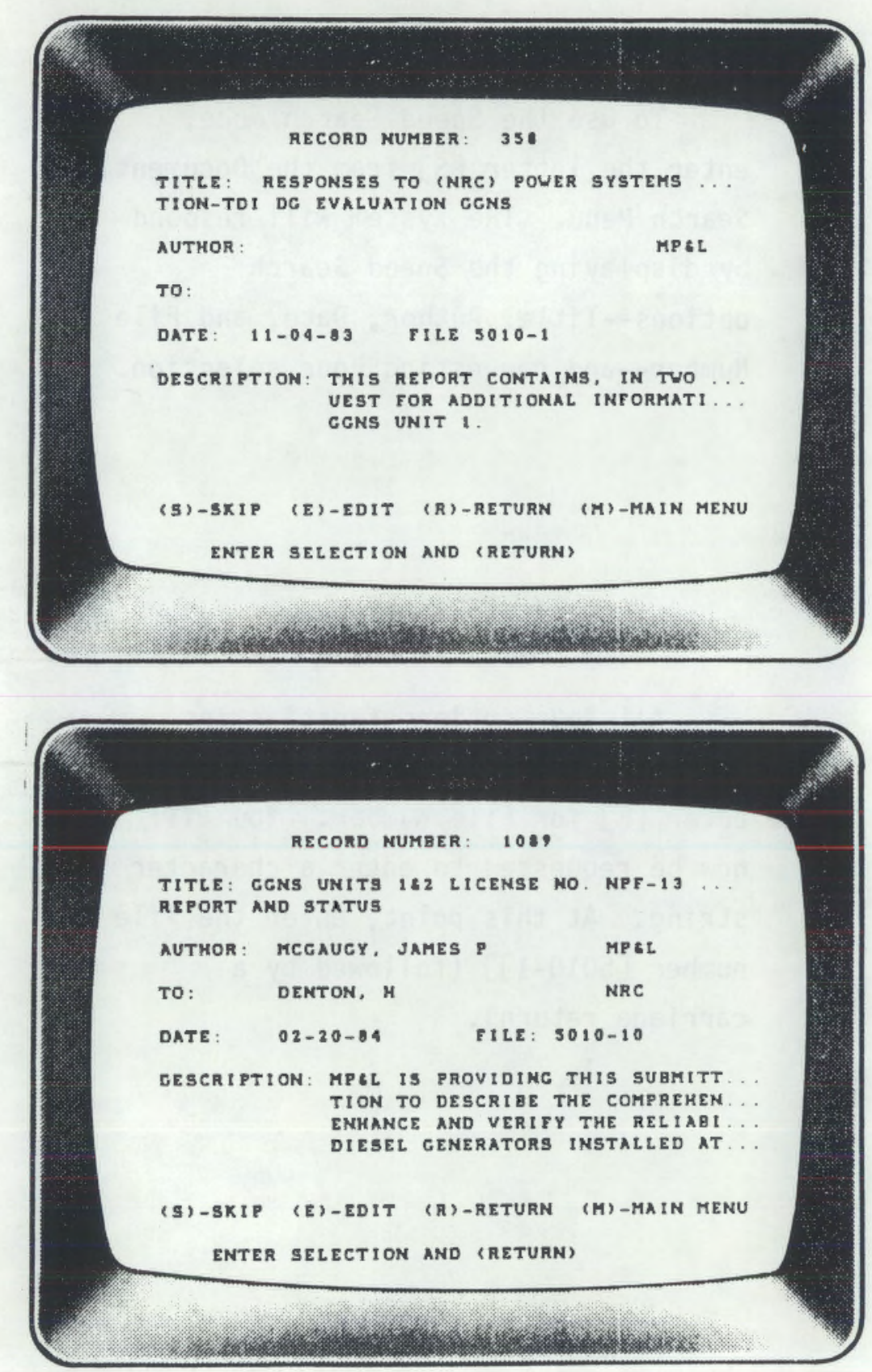
Entering [S10]] will display the tenth record following the currently displayed record, and entering [S-10]] will display the tenth record preceding the currently displayed record. Also, simply entering a carriage return will skip to the next record (equivalent to an [S]] or an [S1]]).

Similarly, if you had searched on date rather than file number, the [S] would skip to the record with the next date (or to the next record with the same date). Thus, the logical ordering of the records will be dependent on the field that is being searched.

Return now to the previous example (file number 5010-1). Entering [E]] will allow you to correct or update the contents of the record. The FILE_NUM cannot be modified in this mode, as it provides reference to the location of a hard copy of the subject document. The DOC_TYP and ISSUE codes also cannot be modified because they are used to determine the file number.

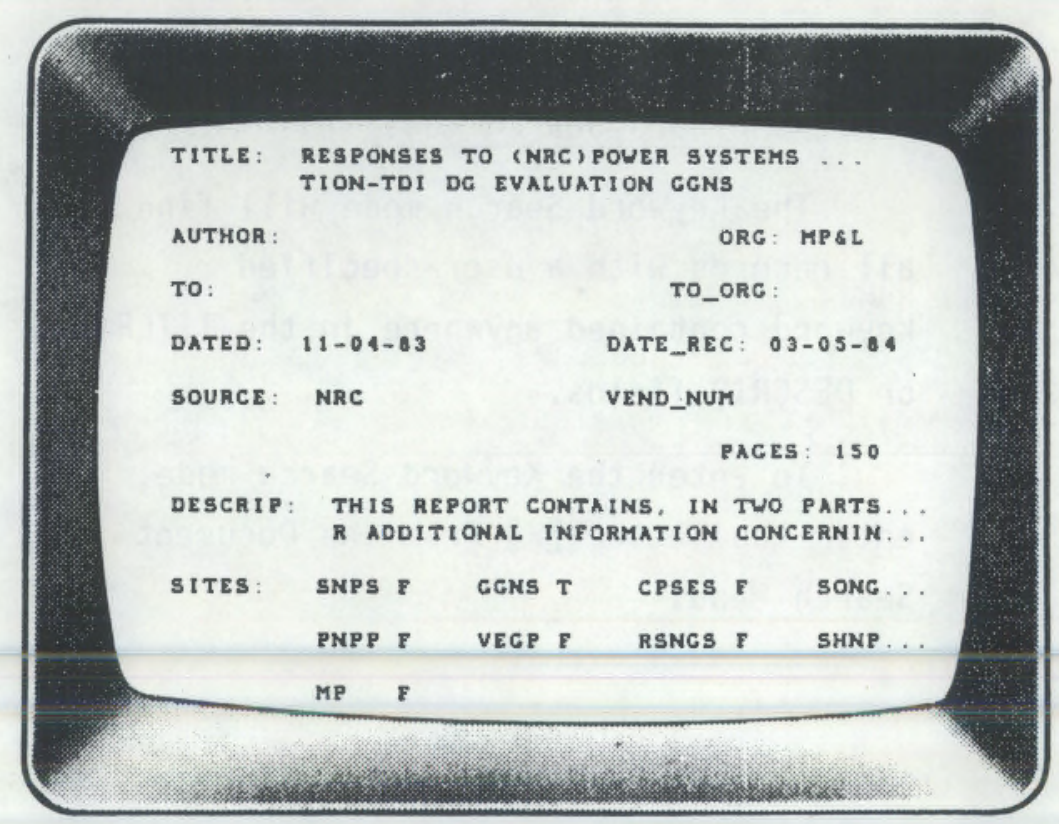


Changes in the file number can be made only by entering the Edit mode from the Main Menu as described in Section 4.3.2.

To exit this mode, you must either depress the "Ctrl" and "W" keys simultaneously (to save the changes) or depress the "Ctrl" and " $Q$ " keys simultaneously (to abandon the changes).

The Return option [R]] will return you to the point at which the field to be searched was specified. Entering [M]] will return you to the Main Menu.

\subsubsection{Keyword Search Mode}

The Keyword Search mode will find all records with a user-specified keyword contained anywhere in the TITLE or DESCRIP fields.

To enter the Keyword Search mode, enter the letter [K] from the Document Search Menu.

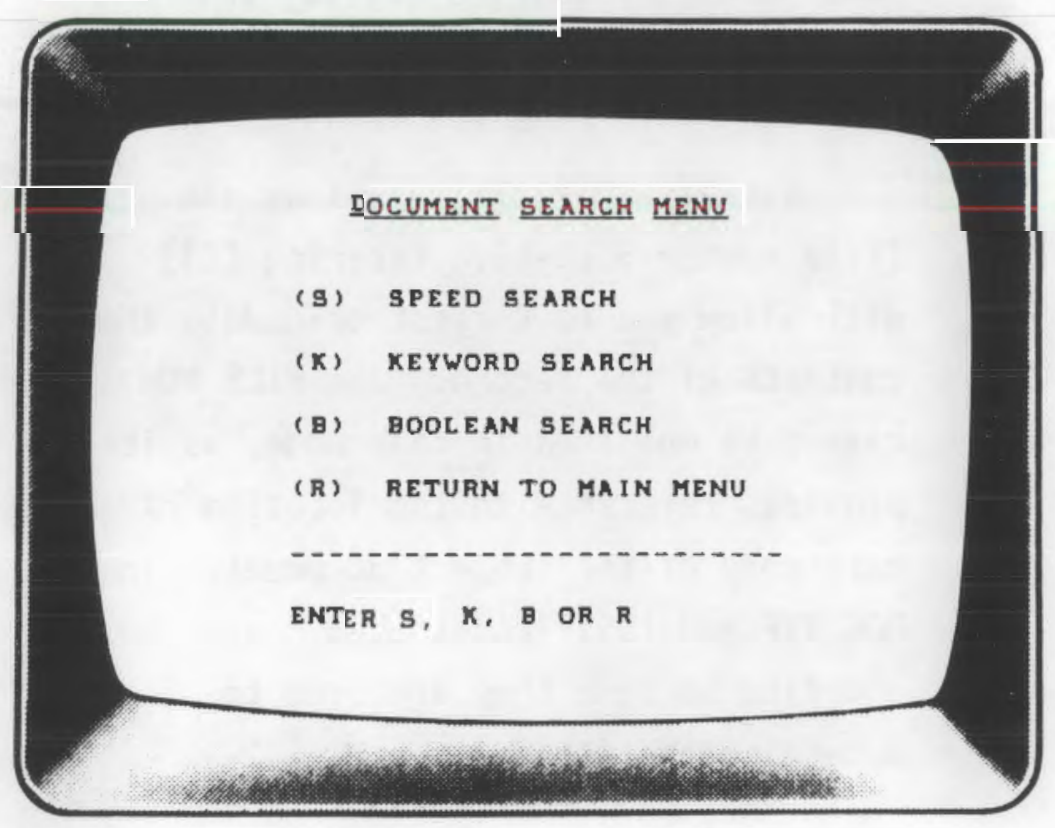


The system will respond by briefly explaining the Keyword Search mode and providing an opportunity for you to return to the Main Menu. (Note that in the Keyword Search mode the output is directed to the printer, so the printer must be on.)

As requested on the screen, depress any key to continue. You are now requested to input the keyword that will be used in the search. The system will print out information on all records containing the specified character string in either the TITLE or DESCRIP fields.
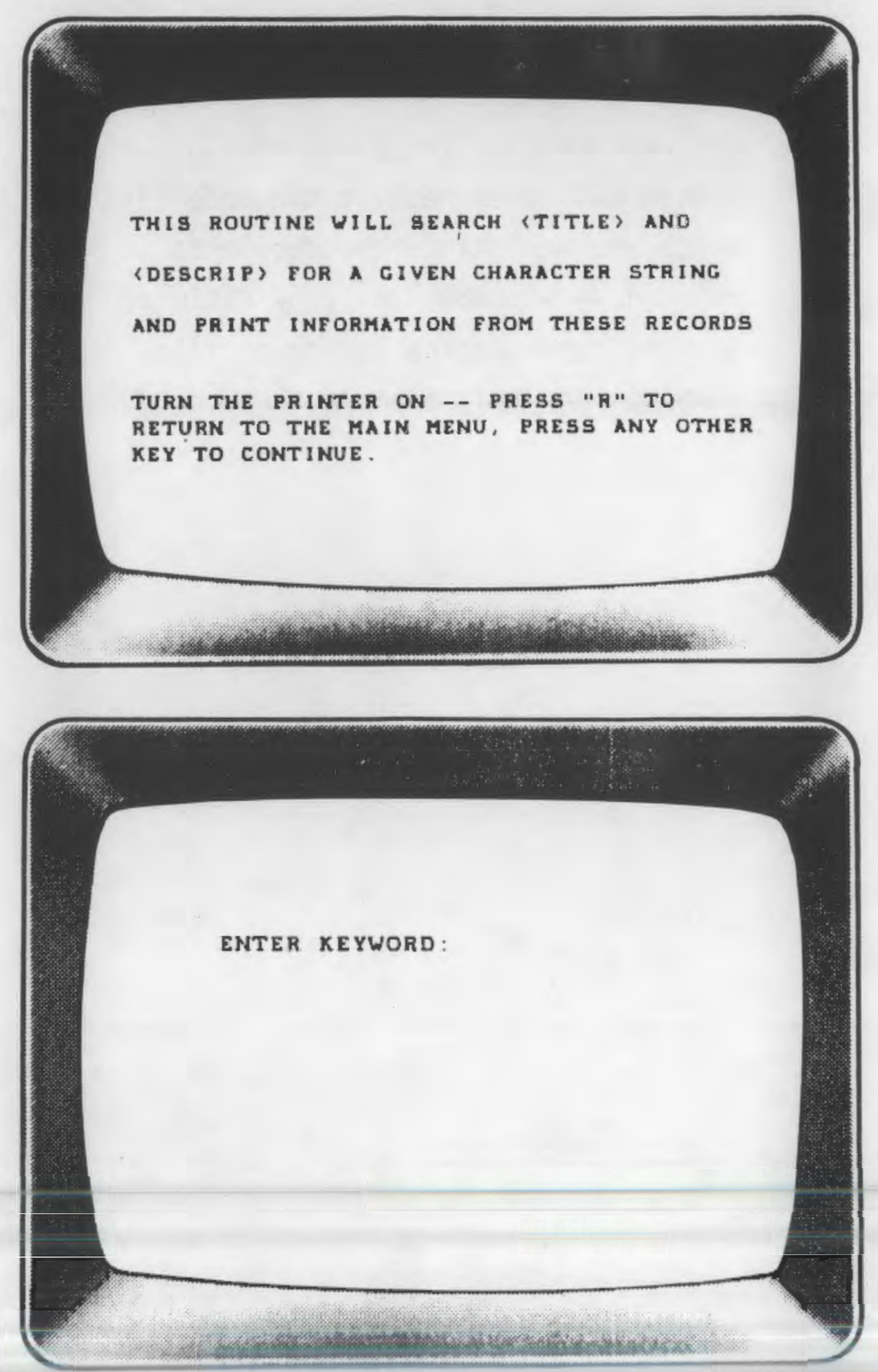
As an example, in response to the system prompt "ENTER KEYWORD", enter the character string [TORSIONAL]]. The system will then request the order in which you would like the documents printed -- alphabetically by title or author, chronologically, or by file number. For this example, enter [0].
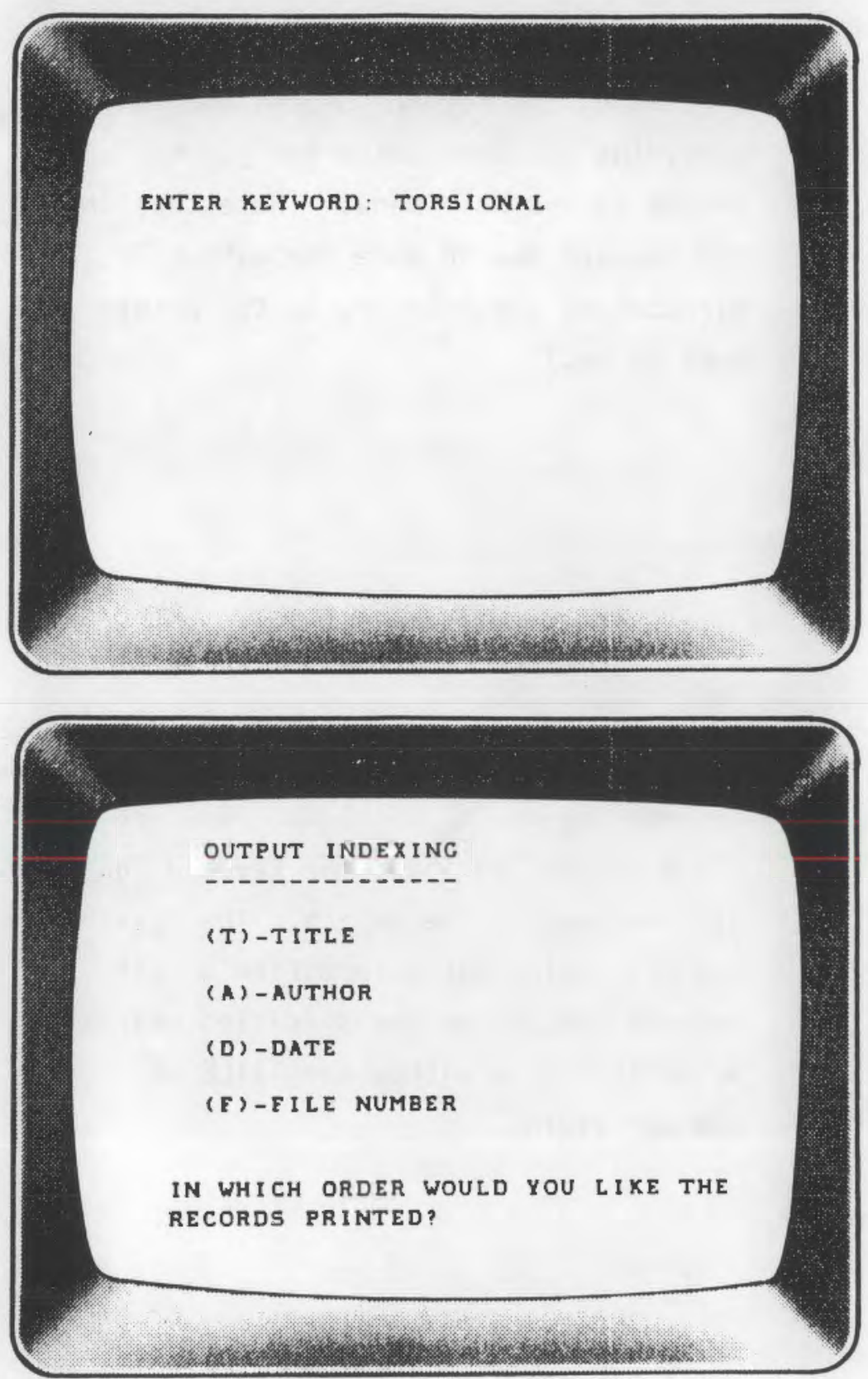

4.10 
The system will now give a choice of reporting formats: a summary format (S) highlighting the record information or an expanded format (E) giving more detailed information.

Make sure that the printer is ready, and enter your selection.

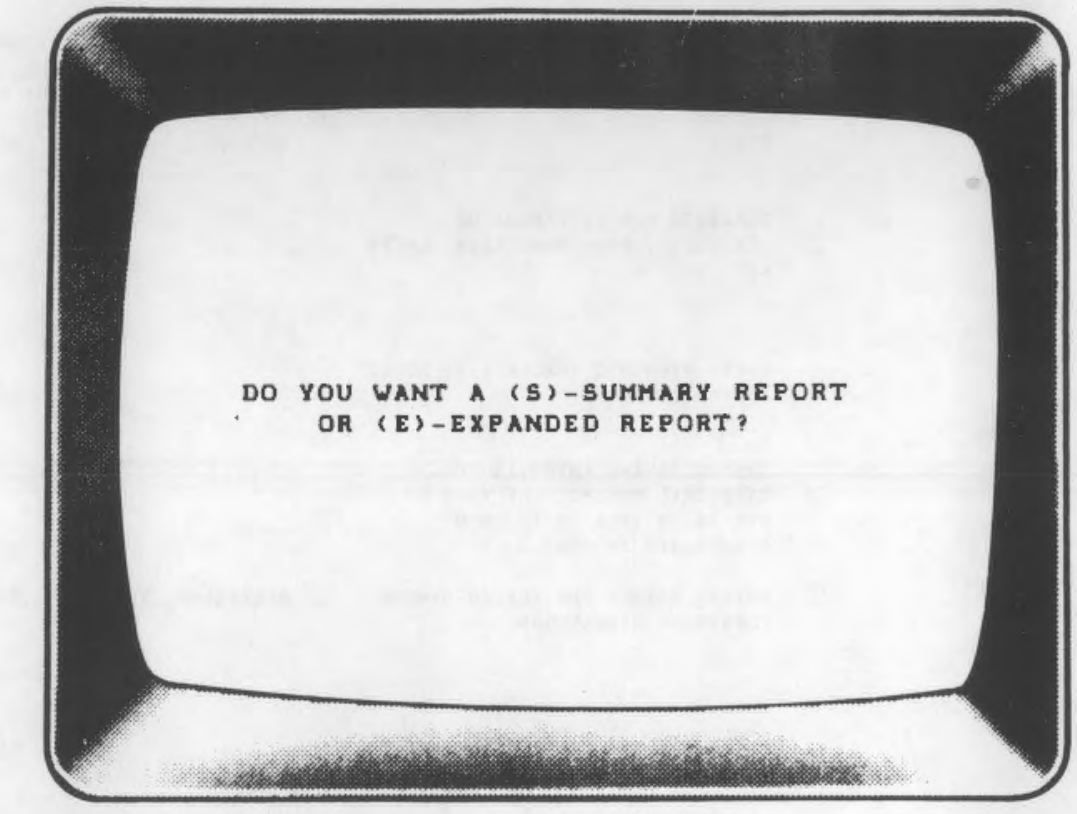

The first page of the output resulting from this example using the summary format is presented in Figure 4.1. The corresponding output for the expanded format appears as

Figure 4.2.

When the search is complete, you will be returned to the Main Menu. 
ERHIDITS FOR TESTIMONY OF SERINGER, BUSH HENRIKSEN, LAITY AND SARSTEN

SHAET RARHONIC ANALYSIS IY MODAL SUPERPOSITION

STIFFNESS AND INERTIAS FOR TORSIONAL DYNAMIC aMaLYSIS OF DSH-41 13 INCH EY 12 INCH CRANXSHAFT AT RES

HOLEER METHOD FOR FORCED-DAMPED TONSIONAL VIBRATIONS

TORSIONAL AND LATERAL CNITICAL SPEED ANALYSIS

TONSIOCRAPH OF CLEVELAND ELECTRIC ILLUMINATING COMPANY ENGINE NO. 35051 GEN SET DSRV-16-4, ,730 АнЕ

PROROSED TONSIONAL AND LATERA CRITICAL SPEED AMALYS:

LILCO DEFICIENCY HEPORT 21, MEGAMDINC CTANSKHATT EDE HOJ

REPORT ON CNANKSHAFT TORSIONA RTESSES - TOT MODEL DSR-

TDI DSH-4I DIESEL ENCINE/GENERATOR

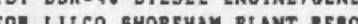
CRANKBHAFT TORSIONAL STRESSES

LETTER TO GERLINGER ON NEQUEST FON APPROVAL OF INDEPENDANT TORSIONAL ANALYSIS OF CMANKSHAFT

"BASED ON THE SUBMITTED TEST DATA, AND ON SUBKITTED

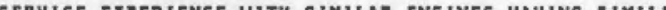
TORSIONAL ERTICA SPEED ARANGEHENT UE ADVISE THAT YOULD HAVE NO OBJECTION TO THE SUEMITTED TOHSIONAL CRITICAL SPEED AMRANGEMENT..."

CRAMKSHAFT TORSIONAL VIERATION ANALYSIS OF $13 / 12$ INCH CHANXSHAFT INDICATON DIACRAH FROM LILCO 13312 TEST AT IOOS LOAD MEASURED IN CYLINDER FIRING CHARACTERISTICS

$5231-29$

$3102-28$

$3102-34$

$0001-11$

THE FORCED AND RESONANT-VIBRATION CHARACTERISTICS OF A TORSIONAL STSTEM ARE EASILY ENOUCH DETERMINED IY THE WAJOR DAMP TNG INFLUENCES AVAILABLE IN THE SYSTEM ARE THOSE OF THE PRIME-MOVER ITSELF.

03-05-73 cory taken mon michoriLn

$3102-32$

CHR ISTIANSEN, ED

$04-12-78$

"PURPOSE - TO VERIEY CALCULATED EREOUENCY AND STRESS LEVEL OF THE TORS ONAL MASS ELASTIC SYSTEM" PERRY NUCLEAR POUER PLANT

TANG, ROLAND

01-22-03 ANALYSES OF ENG INE NUHAERS 74010/12 DELAVAL-ENTERPRI SE ENG INE MODEL DSR-4I 3300 KV/411" GHP AT 450 APM FON

HERLIHT, N

03-12-14 disposition details: SURFace stains have BeEM PREVIOUSLY IDENTIFIED DURING RECOVERY FROM THE PORSIONAL TESTING PEREORMED ON ENG-103 AND ABE ACCEPTABLE ON ALL JOURMAL SUREACES "

YANG, ROLAND

04-04-14 THIS MEPONT CONSISTS OF FOUR SECTIONS AND CONTAINS CXLCULATSONS, TEST DATA AND OPERATING EIPEMIENCE, MHICH TOI CONSIDENS RELEVANT MATERIAL TO ESTAHLISH THE

HANNAN, U⿻

05-03-14 REVIEN OE AMERICAN GUREAU OF SHIPPING REPORT FOR OG.

$3102-11$

DAKLGREN, S.D

$03-16-110$

"IN LIGHT OF OUR CONCENM OVER THE POTENTIAL FOR UNACCEPTAULE TORSIONAL VIQRATIONS IN THE SHOREHAM DOESEL ENCTNE CRANKSHATTS, WE REOUEST YOUR APPROVAL TO OBTAIN AN INDEPENDENT TORSIONAL VIERATION ANALYSIS FOM

FIGURE 4.1. Sample Output Produced by Keyword Search, Summary Format Option 
Mape nation 1

กเזน

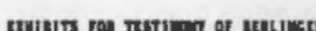

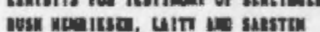

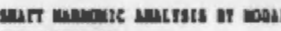

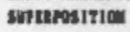

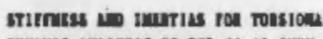
omanic matrass of ose-11 is itex

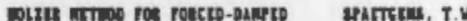

Toustount vilution:

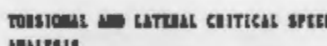
matrsis

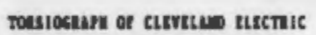

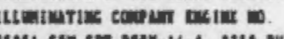

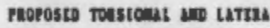
Cniticat setto matzsis

theo oericitucr atront a" tchotuc custurt toc in?

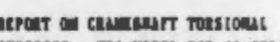
STtsses - To1 moots $031-41$ sthus

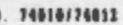

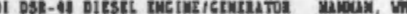
caumsurt rotsiout snessts

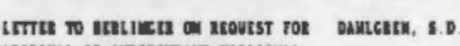
vectsis of chirguart ac outso m

(19-01-30

nเ 14-18-7" versiano, $m e$ svit wit $16316-1$

DEkairio

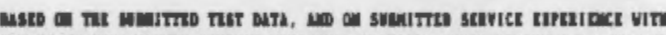

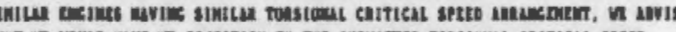
anvenon.

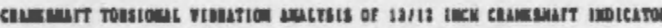

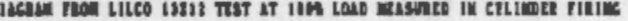
cunctutstits

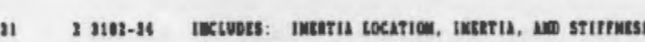

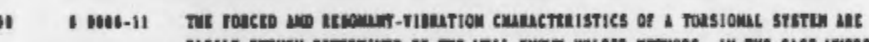

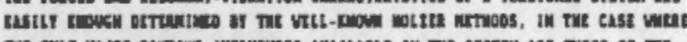

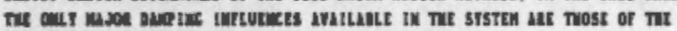
nuts-mova itrutr.

copt nera nou michoritur

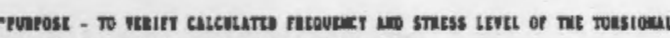

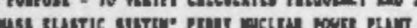

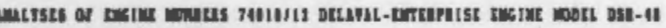

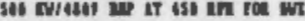

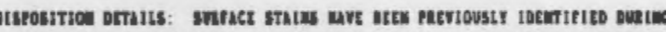

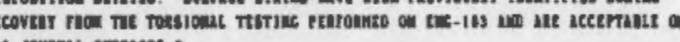
АL Jovient sourscts.

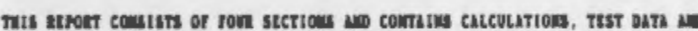

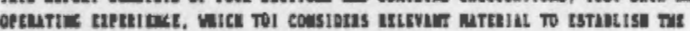

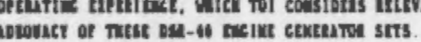

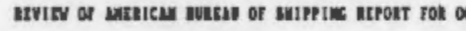

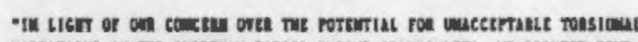

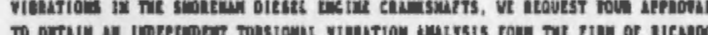
(a)

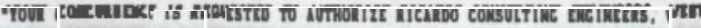

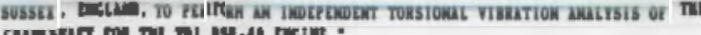

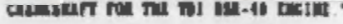

\section{FIGURE 4.2. Sample Output Produced by Keyword Search, Expanded Format Option}




\subsubsection{Boolean Search Mode}

The Boolean Search mode is used when searches more complicated than those just described are required. The Boolean search mode will allow you to perform searches based on multiple conditions as described in the following paragraphs.

To enter the Boolean Search mode, enter the letter [B] from the Document Search Menu. The system will respond by briefly describing the Boolean Search mode and providing you with the option of continuing or returning to the Main Menu.
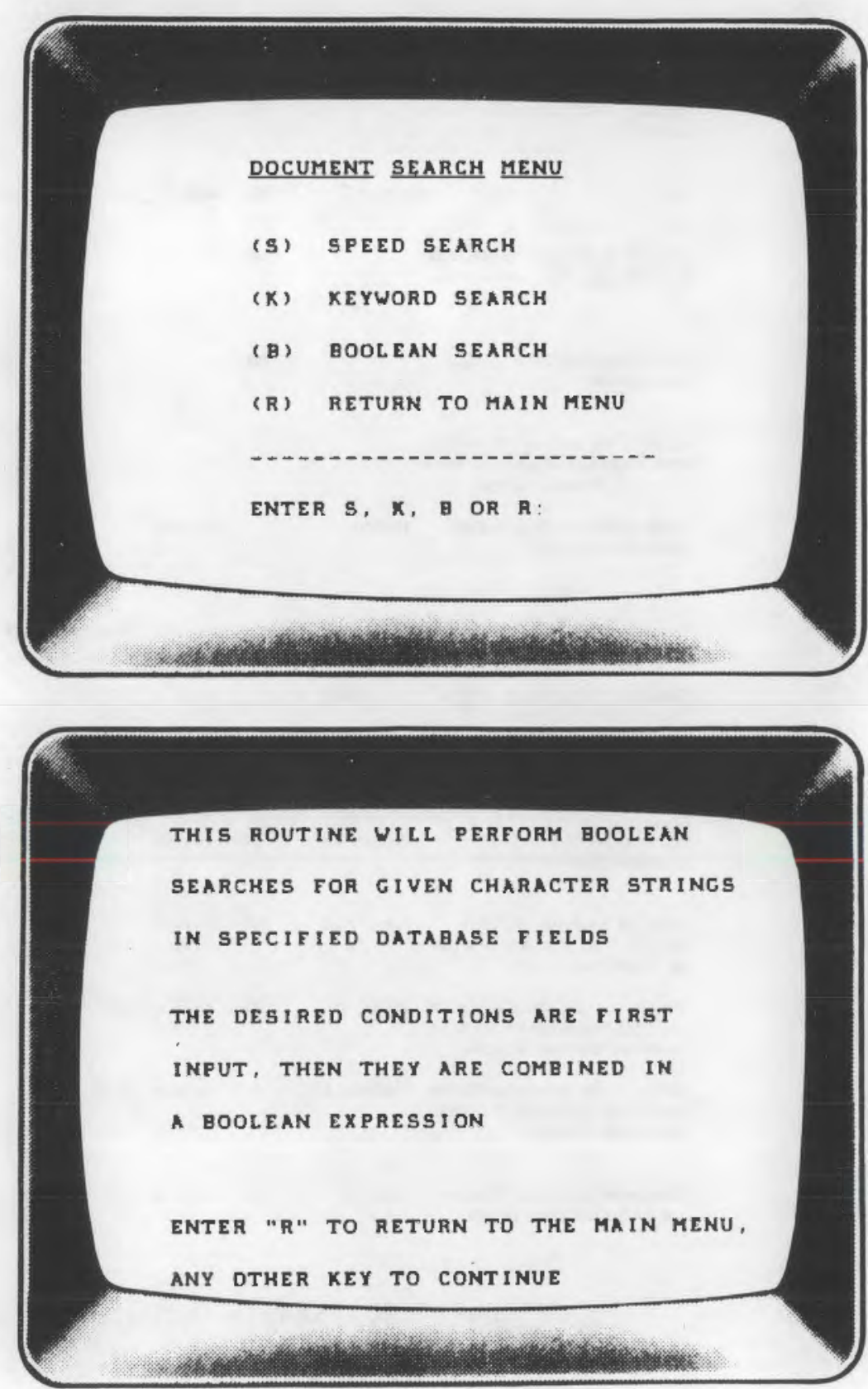

4.14 
Depress any key to continue. The screen will now display the field names in the document database and prompt you to enter a search condition. In response to the prompt "ENTER CONDITION:", enter the desired test criterion. For example, enter [DATED $>1-1-85]$ ] to search for documents dated after January 1, 1985.

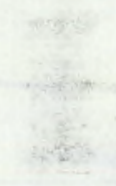

Following the carriage return, the system will prompt you for more input. As an example, enter [DATED<2-1-85]] to search for reports dated earlier than February 1 , 1985.

As a third criterion, enter ISSUE $=331$ to specify crankshaft reports.

Finally, enter [SNPS=T]] to indicate that only documents pertaining to the Shoreham Nuclear Power Station are to be included.
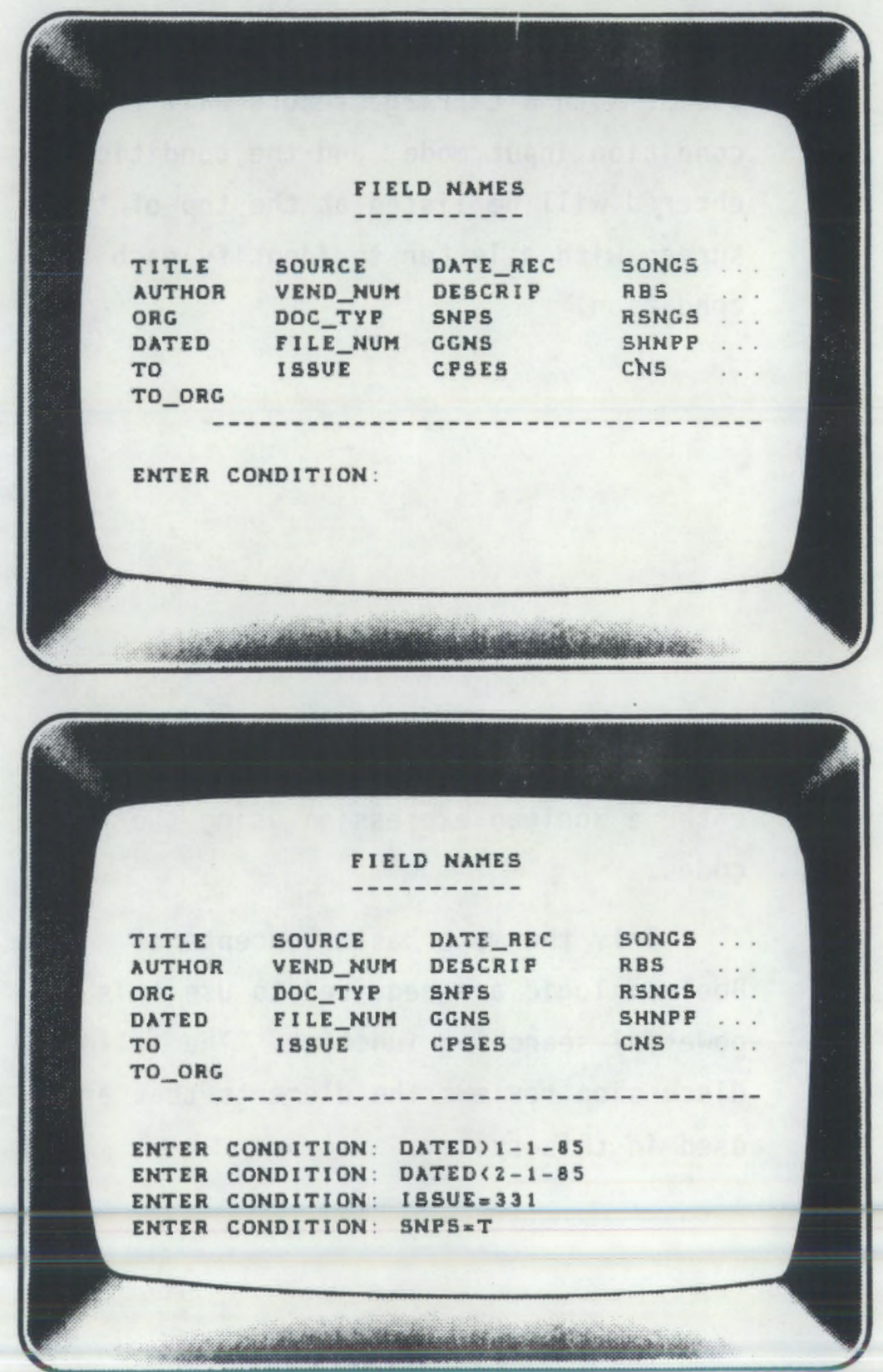
Responding to the "ENTER CONDITION:" prompt wi.th a carriage return will end the condition input mode, and the conditions entered will be listed at the top of the screen with a letter to identify each condition.

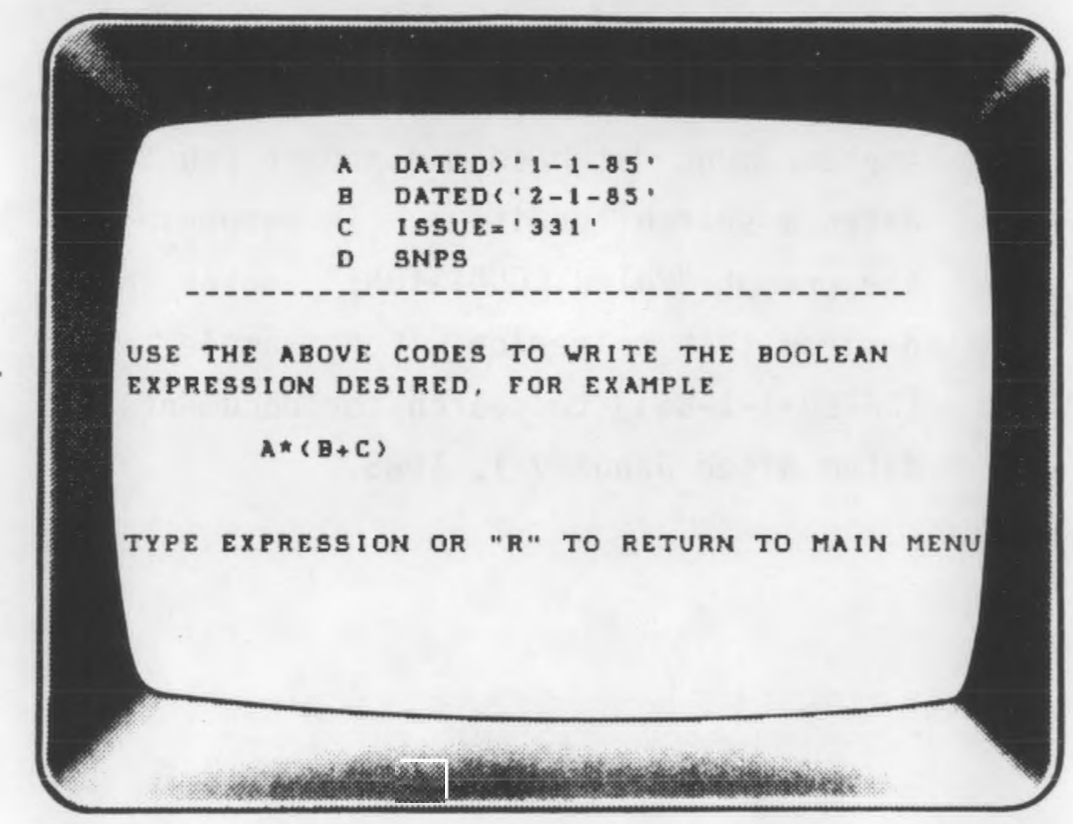

The system will then invite you to enter a Boolean expression using the above codes.

Only the most basic concepts of Boolean logic are required to use this powerful searching function. The following discussion reviews the elements that are used in this system. 
The search conditions (currently displayed) may be combined with AND and OR statements to provide a very specific search. In the document database the symbol "*" is used to represent the AND function, while "+" is used to represent the $O R$ function. This nomenclature is consistent with most texts on Boolean logic.

If you input the condition $A+B$ ( $A$ or $B)$, records satisfying either condition $A$ or condition $B$ (or both condition $A$ and $B$ ) will be identified.

If you input the condition $A * B$ ( $A$ and $B)$, then only records simultaneously satisfying conditions $A$ and $B$ will be identified.
Parentheses may be used to group conditions. For example, $A^{\star}(C+D)$ will identify records that satisfy condition $A$ and either (or both) conditions $C$ or $D$. In the example now on the screen, this would correspond to identifying all documents dated later than January 1, 1985, and either relevant to crankshafts or relevant to Shoreham, or relevant to both crankshafts and Shoreham.

Similarly, if you wanted all documents pertaining to crankshafts on the Shoreham engines that are dated later that January 1, 1985, then the appropriate Boolean expression would be $A^{\star} C C^{\star} D$.

The types of conditions that may be input in response to the "ENTER CONDITION:" prompt are summarized in Table 4.2. 
TABLE 4.2. Boolean Search Conditions

\begin{tabular}{|c|c|c|c|}
\hline Condition & Symbol & Example & Description \\
\hline \multirow[t]{3}{*}{ EQUAL TO } & $=$ & AUTHOR=DODGE & Test that the document author is Dodge \\
\hline & & SNPS $=T$ & $\begin{array}{l}\text { Test that the document pertains to the } \\
\text { Shoreham Nuclear Power Station }\end{array}$ \\
\hline & & TITLE $=$ DESIGN RE & $\begin{array}{l}\text { Test that the title begins with the } \\
\text { character string DESIGN RE" }\end{array}$ \\
\hline \multirow[t]{3}{*}{ GREATER THAN } & $>$ & DATED $>1-1-85$ & $\begin{array}{l}\text { Test that the document is dated after } \\
\text { January } 1,1985\end{array}$ \\
\hline & & DOC_TYP>20 & $\begin{array}{l}\text { Test that the document type code is } \\
\text { greater than } 20 \text { (i.e., } 21 \text { to } 24 \text { ) }\end{array}$ \\
\hline & & AUTHOR>SMITH & $\begin{array}{l}\text { Test that the author's name would } \\
\text { lexically follow SMITH }\end{array}$ \\
\hline \multirow[t]{3}{*}{ LESS THAN } & $<$ & DATED $<1-1-85$ & $\begin{array}{l}\text { Test that the document is dated before } \\
\text { January } 1,1985\end{array}$ \\
\hline & & DOC_TYP $<20$ & $\begin{array}{l}\text { Test that the document type code is less } \\
\text { than } 20\end{array}$ \\
\hline & & AUTHOR $<$ SMITH & $\begin{array}{l}\text { Test that the author's name would } \\
\text { lexically precede SMITH }\end{array}$ \\
\hline \multirow[t]{3}{*}{ NOT EQUAL TO } & $\#$ & AUTHOR\#DODGE & Test that the document author is not DODGE \\
\hline & & SNPS\#F & Same as SNPS $=T$ \\
\hline & & ISSUE\#331 & $\begin{array}{l}\text { Test that the issue code is not } 331 \\
\text { (crankshaft) }\end{array}$ \\
\hline
\end{tabular}


TABLE 4.2. (contd)

\begin{tabular}{|c|c|c|c|}
\hline Condition & Symbol & Example & Description \\
\hline \multirow{3}{*}{ SUBSTRING SEARCH } & $\$$ & DATED $\$ 85$ & Test that the document is dated in 1985 \\
\hline & & DESCRIP\$TORSIO & $\begin{array}{l}\text { Test that the character string TORSI0 is } \\
\text { in the DESCRIP field (Note: This will } \\
\text { identify words containing the substring, } \\
\text { e.g., TORSIOGRAPH). }\end{array}$ \\
\hline & & TITLE\$DR/QR & $\begin{array}{l}\text { Test that the character string } D R / Q R \text { is } \\
\text { in the title }\end{array}$ \\
\hline
\end{tabular}


To find all documents pertaining to Shoreham or crankshafts and dated between January 1 and February 1, 1985, for the current example, enter:

$$
A \star B \star(C+D)
$$

The system will then provide the choice of screen or printer output. The screen output, which is obtained by depressing [S], will display the TITLE, FILE NUM, AUTHOR, and DATED fields of documents satisfying the input criteria. These references will be displayed six at a time on the screen to give you an opportunity to read them. To view subsequent references, simply depress any key, and the next six references will be displayed. After all applicable records have been displayed, you will be returned to the Main Menu. The screen output corresponding to the above example is reproduced in Figure 4.3 .
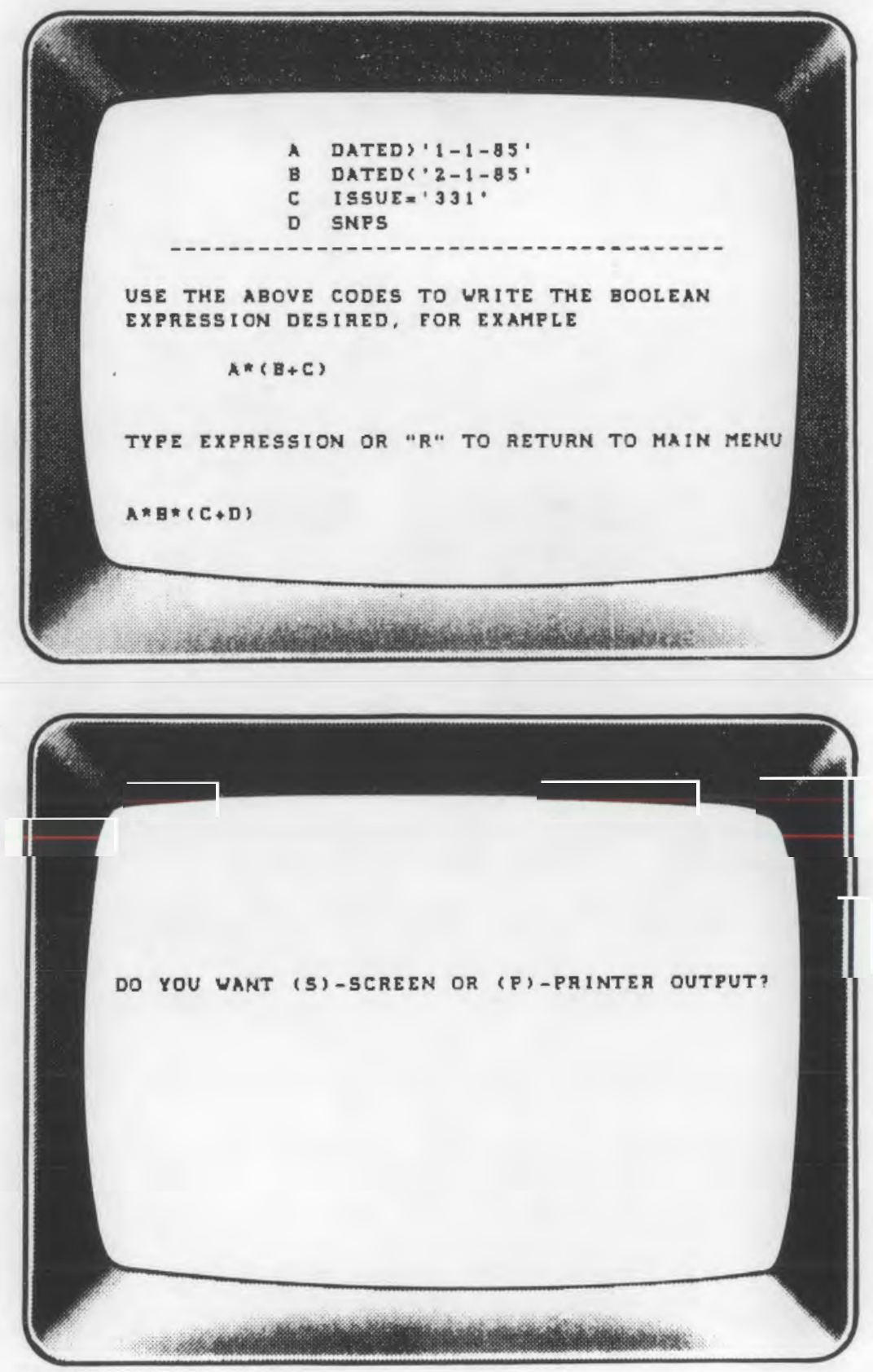

L. O.T. JOINT MOTION OF SUTFOLK COUNTY AND NEW YORK STATE TO ADMIT EDG $5220-23$ LOAD CONTENTION

Press any key to continue.

L O T DRAFT-TER FOR THE TDI DIESEL GENERATOR DR/QR REPORT: SHOREHAM $5220-24$ - NESBITT, JOHN $01-00-85$

REOUEST FOR RELIET FAOM OFERATING RESTRICTIONS ON CPSES UNIT I TDI DIE 5316-3
SEL GENERATORS SEL GENERATORS

STIPULATION: SUFF COUNTY DOES NOT INTEND TO SEEK TO DISOUALIFY BLOCK O S221-BB N BABIS OF CAM GALLERY CRACKS - PERLIS

$01-09-85$

CAST IRON ANALYSIS RE:

LILCO VS. SUFFOLK COMPANY

- MCCFONE, WALTER C.

$5202-5$ $01-11-95$

LILCO UNIT I DOCKET NO.50-322-OL- WITHDRAWL OF CRANKSHAFT CONTENTION

$5221-90$ - GRIGATI, J.J $01-11-85$

DIESEL GENERATOR QUALIFIED LOAD TESTIMONY OF G. DAWE, J, NOTARO AND EI S221-96 YOUNGLING ON BEHALF DF LILCO -

$01-15-85$

Press any ker to continue...

FIGURE 4.3. (contd) 
If printer rather than screen output is selected (by depressing $[P]$ ), then you are given the choice of summary or expanded output.

DO YOU WANT (S) -SCREEN OR (P) - PRINTER OUTPUT?

DO YOU WANT (S)-SUMMARY PRINTOUT OR

(E) -EXPANDED PRINTOUT?

A copy of the first page of the summary output from the above example is given in Figure 4.4; the corresponding expanded output is given in Figure 4.5. 
Page No.
osi11ios

TITL

MEMORANDUM AND ORDER RULING ON

ADHISSINILITY OF ENERGECY DItSEL
GEMERATOR LOAD CONTENTION 1-11-AS

DRATT- MOTIFICATION OF PRIOH

CONAI THENT OF DR IUSH DURIMG THE

urek of FEHRUahy 11, 19:5

C.O.T. - YOUR LETTER TO FHAMK

zALOUDEX. DATED DECEMJER 26,1119

OATA SHEET CEIO TEST PROCEDURE TOR LILCO ELECTRICAL SVITCHAOAND

INSTRUMERTTS

LIQUID PENETRANT BIAMINATION COLOR CONTRAST - SOLVEST AEMOVALLE METHOD

L. O.T. JOINT MOTION OF BUFrOLK

COUNTY AND NEW YONX STATE TO ADHIT

EDE LOAD CONTENTIOM

L.O.T. DRAFT-TEN FON THE TOI DIESE GENERATOR DR IOA REPORT: SHOREHAM

REQUEST FOR RELIEF rNOM OPERATINC RESTRICTIONS ON CPSES UNIT I TOI

STIPULATIOK: SUFF COUNTY DOES MOT INTEND TO SEEK TO DI SOVALIFY JLOCK ON UASIS OF CaM GaLLERY CRACKS

CAST IRON ANALYSIS RE: LILCO VB. surtolx company

LILCO UNIT 1 DOCXET NO 30-333-OL VITHDAMUL OF CRAMXS

OIEsTL CENERATOR QUALIFIED LORD TESTIMONY OF $C$. DAUI, J. NOTARO AND 2 YOUNGL IMG ON BEHALF OF BILCO

CHLC antE ON THE APPLICABItTy or EDE LOAD CONTERTIOM
--- SUMFART OF REPOHTS FHOK THE ADERO DATABABE -.-

AUTRO

DATE dECRiption

IIte

DYMEER, ALAK HOY

01-02-05

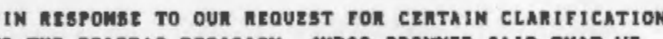
THE THE WICH VILL IXPLAIM THE IASES FOR THE DOARD'B DECISTON.

01-03-89 "THE LICENBING DOAND KAS AMNOUNCED ITS IRTEKTION TO ecoovers

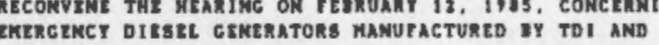
IMSTaLTo AT THE SMPS."

DODGE, RYAN

$01-04-65$

$01-04-95$

$3204-5$

01-06-03 PURFOSE : TO ESTABLISH THE REOUIREMENTS FOR THE LIOUID PENETRAKT ETAMINATIOM OE NONPOROUS MATERIALS AND VELDS

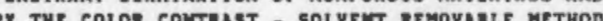

$01-07-03$

$01-08-93$

01-01-09

TEZAS UTILITIES SUAHITs THAT OPERATINC DATA OBTAINED ON TWO TDI DIESEL ENGINES AT DUKE POUER'S CATAUBA NUCLEA RELIABILITY OE THE TDI ENGINES AT THOSE SITES AS YELL AS THOSE AT CPSES

01-89-es -This Eviozmce supponts the conclusion that the cah CALLERY CRACKB IN THE ORICINAL EDG 103 DLOCK DID NOT PROPAGATE DURTMG ON AS A RESULT OF OPERATION.

MCCrons, WALTER 01-11-13

$01-14-13$

"WE ARE AUTHORIzED TO STATE THAT THE STATE OF MEW YORX HAS NO ONJECTION TO THE VITHDRAVAL OF TKE CRANKSHAFT ISBUE TO THE LIMITED EITENT DEACRIJED."

$01-15-05$

$11-06$

01-13-AS TON DECEMIEn 21,19, J. BREMUER MOTIFIED LILCO AND

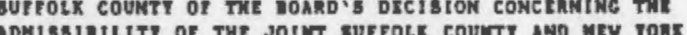

FIGURE 4.4. Sample Printer Output Produced hy Boolean Search, Summary Format Option 
sacentums

nims

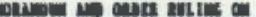

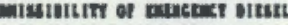

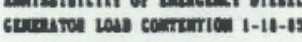

min- Gritcarie o nie

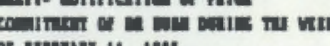

1.0.T. - $100 \mathrm{trm}$ to $\mathrm{nux}$

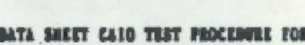

litco tutenicat mintuous

innuming

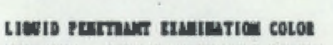

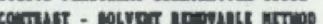

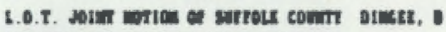

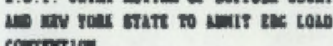
contumion

6.0.т. ourr-me ron me no pissu

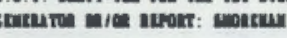

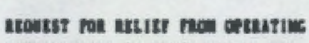

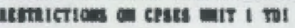
טเsts curutons

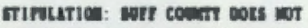
usis or cul catur chets

Cast now matris at: Lteo is. surtous comons

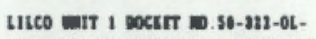
virment of castsurt comratio

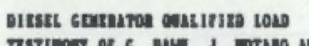

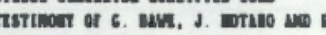

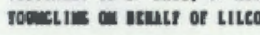

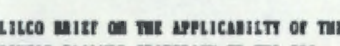

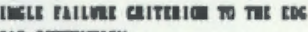

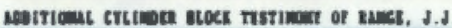

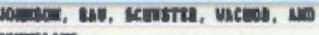

urmon anc MTE To

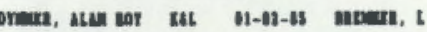

และ (1-13-13

Doost, nux

PII 11-11-1s Lontery, $\mathrm{P}$.

ans 11-016-15

Iat N1-16-15

m 11-19-1s cansvitum

manก, soln

ater, som

Puns

nccaona, vatru mal 11-11-4!

meatı, ง.ง.

ab1 |1-13-13

ast) 11-15-15

mi MI-13-12

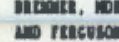

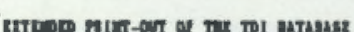

anc ronct IU TI IIS

ac coovins sst 11 sazi-110

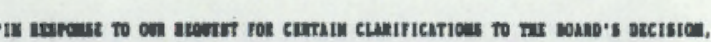

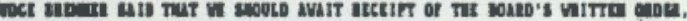

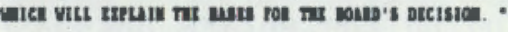

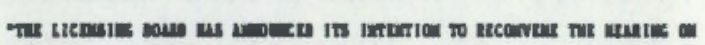

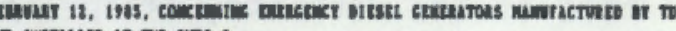
irstite is ne cose.

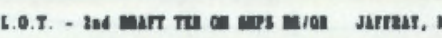

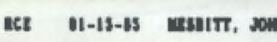

ne

$352 \quad 21$ sม1- 


\subsection{USING THE REPORTING FUNCTIONS}

Several special report forms have been provided with the document database system. These report forms are designed to provide information on the entire database or on a subset of the database, as specified by the user.

In addition, it is possible to create custom report forms using the reportgenerating features built into dBase III. Section 4.3.1 will demonstrate the projectspecific report forms that have been provided. Section 4.3 .2 will briefly discuss the dBase III report-generating features.

\subsubsection{ADERO Report Formats}

To generate a standard report from the document database, go to the Main Menu as described in the preceding section. From the Main Menu depress "4".

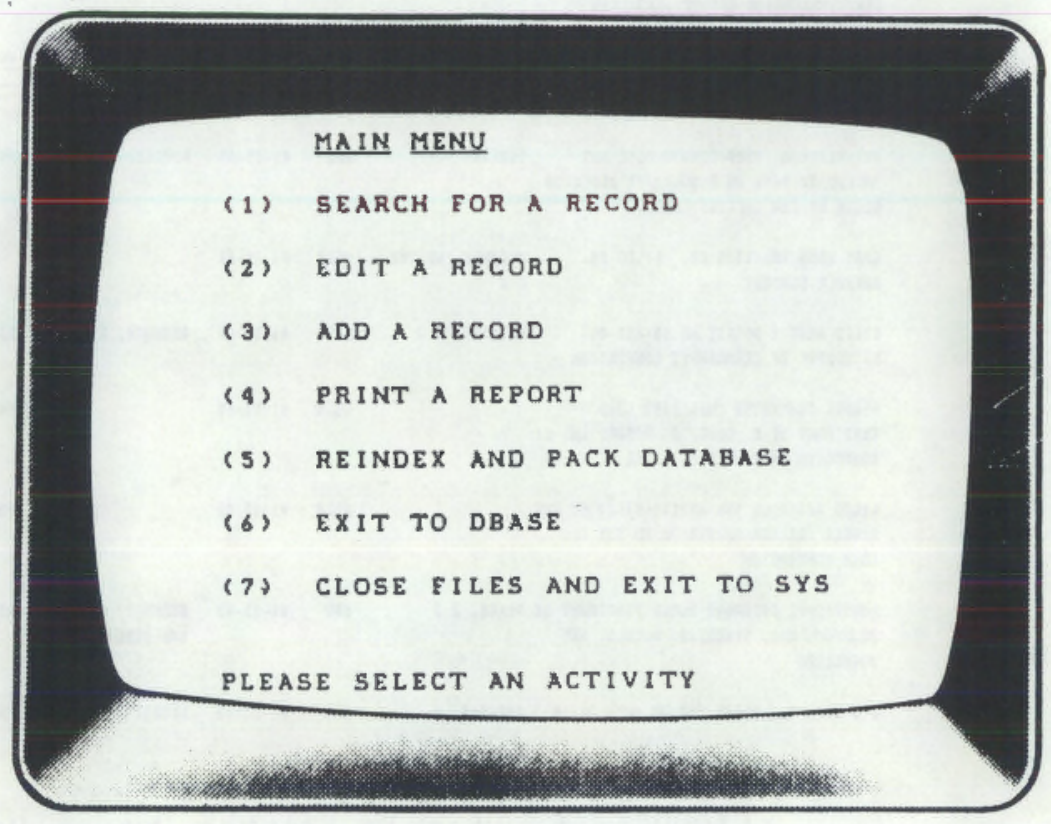


The system will respond with the Report Menu. This menu offers five different report formats:

\author{
EXECUTIVE SUMMARY \\ FORMAL SIJMMARY \\ EXPANDED REPORT \\ QUICK SUMMARY \\ GENERIC ISSUE TRACKER
}

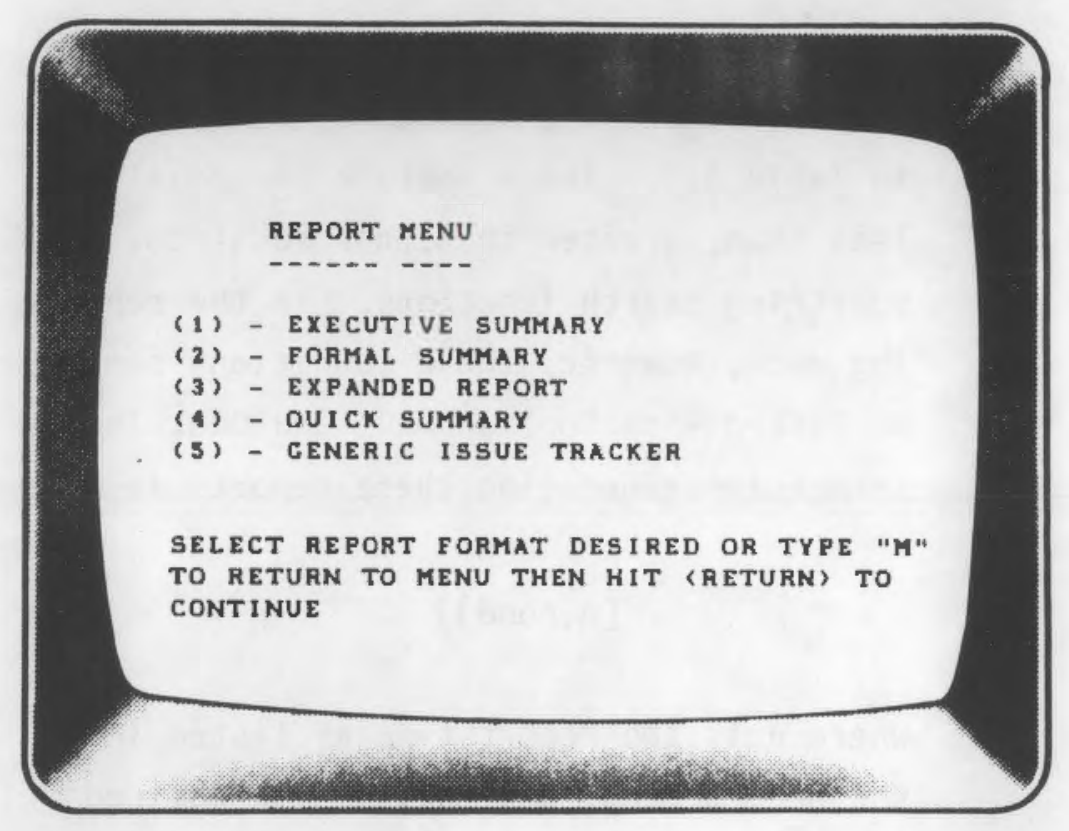

These formats provide a variety of information on the documents in the database. Select any of these formats by depressing the number to the left of the desired format followed by a carriage return. This will provide a printout of the entire database. It is also possible to specify simple conditionals. This will enable you to generate a report that includes only those references that satisfy the specified condition. 
The conditions that can be applied to reports are the same as those summarized in Table 4.2. These include the equal to, less than, greater than, not equal to, and substring search functions. In the reporting mode, however, these conditions cannot be linked with Boolean ANDs and ORs. The format for generating these reports is

$$
[n, \text { cond }]]
$$

where $n$ is the report type as 1 isted in the Report Menu, and cond is the desired condition.

The following examples illustrate the various reporting formats and show how to include conditionals. For brevity, only the first page of each sample report will be included in the accompanying illustrations.

Before initiating any of these reports, make sure the printer is turned on.
Responding to the system prompt from the REPORT MENU with

$$
[1, \text { DATED }>12-31-84]]
$$

will provide an executive summary report listing documents dated later than 1984 . The first page of this report is shown in Figure 4.6.

Similarly, responding with

$$
[2, \text { ISSUE }=331]]
$$

will generate a formal summary report listing documents pertaining to crankshafts. This report is illustrated in Figure 4.7 .

Entering

$$
[3, \text { AUTHOR }=\text { LOUZECKY }]]
$$

will generate an expanded report listing documents in the database that were authored by Mr. Louzecky. The first page of the resulting report is shown in Figure 4.8 . 


\begin{tabular}{|c|c|c|c|c|c|}
\hline $\begin{array}{l}\text { FILE } \\
\text { No. }\end{array}$ & TITLE/SURJECT & AUTHOR & onc. & $\begin{array}{l}\text { DOC. } \\
\text { DATE }\end{array}$ & $\begin{array}{l}\text { DATE } \\
\text { RECEIVED }\end{array}$ \\
\hline $0000-11$ & $\begin{array}{l}\text { HOLZER METHOD FOR FORCED-DAMPED TORSIONAL VIBRATIO } \\
\text { NS }\end{array}$ & SPAETGENS, T.U. & & 01-MAR-50 & $07-3 E P-84 E$ \\
\hline $0000-12$ & $\begin{array}{l}\text { THE DEVELOPMENT OF A HIGHLY RATED MEDIUM SPEED DIE } \\
\text { SEL ENGINE OF }, 000-9,000 \text { NORSEPOWER... }\end{array}$ & POPE, J. A. & IME & $01-J A N-66$ & $22-3 E P-84 E$ \\
\hline $3000-1$ & $\begin{array}{l}\text { PISTON RING SCUFFING-A BROAD BURVEY OF PROBLEMS AN } \\
\text { D PRACTICE }\end{array}$ & MEALE, M.J. & & $01-$ FEI-71 & $07-3 E P-84 E$ \\
\hline $5005-2$ & $\begin{array}{l}\text { TECHNICAL BPECIFICATION FOR STANDEY DIESEL GENERAT } \\
\text { ORB FOR MPGL CO. GGMB I AND } 2\end{array}$ & & ВЕСH & $01-0 C x-73$ & O5-MAR-14 \\
\hline $5005-1$ & $\begin{array}{l}\text { DESICN SPECIFICATION FOR STANDEY DIESEL GENERATORS } \\
\text { FOR MPGL, GGNB } 1 \text { AND } 2\end{array}$ & & ВЕСH. & $12-J U L-74$ & 05-MAR-84 \\
\hline $5105-2$ & $\begin{array}{l}\text { DIESEL ELECTRIC GENERATING UNITS (CATAWBA MS I AND } \\
\text { 2) }\end{array}$ & & DUKE & $03-0 C T-74$ & $12-A P R-84$ \\
\hline $0008-8$ & $\begin{array}{l}\text { TESTS OF RAYCHEM FLAMTROL INSULATED AND JACKETED E } \\
\text { LECTRICAL CABLES UNDER SIMULTANEOUS EXPOSURE TO . }\end{array}$ & & FIRE & $01-J A N-75$ & $04-8 E P-84 E$ \\
\hline $3102-32$ & TORSIONAL AND LATERAL CRITICAL SPEED ANALYSIS & & TDI & 05-MAK- 75 & $23-F E B-A 5 E$ \\
\hline $0005-5$ & $\begin{array}{l}\text { IEEE STANDARD CRITERIA FOR DIESEL GENERATOR UNITS } \\
\text { APPLIED AS STANDEY POWER SUPPLIES FOR NUC PUR GS }\end{array}$ & & IEEE & $09-8 E P-76$ & \\
\hline $5206-6$ & $\begin{array}{l}\text { CHECKOUT AND INITIAL OPERATIONS TEST PROCEDURE FOR } \\
\text { CP UATTMETER - EDG 1OS AT SHOREHAM }\end{array}$ & & & $01-F E B-77$ & $21-J A N-85$ \\
\hline $0010-1$ & $\begin{array}{l}\text { PERIODIC TESTING OF DIESEL GENERATOR UNITS USED AB } \\
\text { ONSITE ELEC POWER SYSTEHS AT NUCLEAR POWER PLANTS }\end{array}$ & & NaC & $01-A U G-77$ & $00-A U C-77 S$ \\
\hline $5205-1$ & $\begin{array}{l}\text { SECTIONS OF SHOREHAM FBAR RELATING TO STANDBY DIES } \\
\text { EL GENERATORS }\end{array}$ & & ENPS & $01-A U G-77$ & \\
\hline $5006-4$ & $\begin{array}{l}\text { QUAL1FICATION TEST FOR DE LAVAL ENGINE GENERATOR S } \\
\text { ET GGNS } 1 S 2\end{array}$ & REID， DENMIS & TDI & 30-NOV-77 & 05-MAR-14 \\
\hline $3100-3$ & $\begin{array}{l}\text { FATICUE PROPERTIES OF FULL SCALE FORGED AND CABT S } \\
\text { TEEL CRANKSHAFTS }\end{array}$ & NISHIHARA, M. & KOEE & $26-J A N-70$ & $30-A P R-85$ \\
\hline $0008-13$ & $\begin{array}{l}\text { SULZEF'S FOUR-STAOKE HIGH-AKD MEDIUM SPEED ENCINE } \\
\text { RANGE }\end{array}$ & LUSTGARTEN, C & SHE & O1-FEE-70 & $22-B E P-84 E$ \\
\hline
\end{tabular}

FIGURE 4.6. First Page of Executive Summary Report for "DATED>12-31-84" 
Page no.

TITE

CRankshart stazss amaLysis pmognah

REsponsts to NaC QUrstions on CRANXSHAFT REPOHT

EVALUATION OF TDI CAMAKBMATts, NOTES ON SHOT PEEMINE

LOAD ENGINE HOURS FOR SKOREMAM SHATT HARMONIC AMALSIS IY RODAL SUPERPOSITIOM

DETERKIMATION OE SUITADILITY OF TOI DSR4: EKG INE CRAMXSHATT AT SHORHAM

STIFENESE AKD INERTIAS FOR

TORsionaL oYwamic AMALTSis or

DBR-42 13 INCH II 12 INCH

CAAMXSHAFT AT RIS

KRUPP INSPECTION TEST CERTIFICATE YOR TKE BHOLEHAM CRAKKBHATT

TOT MODE: DSR-4E RivEK aEND HUCLEA PONER STATION MASS ELASTIC SYSTEM

EVALUATION OF THANSIETT CONOITIONS ON EMzRCEMCY DIESEL GEMELTTO

CHAMKSHAETS AT SAM ONOERE UNIT

TORSIONAL AND LATRALL CRITICAL SPED ANALYSIS

FATICUE PHOPERTIES OF FULL SCALE COACED AND CAST STEEL CAMYXSHAFT:

ExPLAMATORY MOTES ON nULES

"CALCULATION OF ChakKenafts ton Disst. EMG INEs"

ANAMAX CRANKSHAFT FALLURE ANALTSIS
SEARCM CONDITION : 2, 138UE=331

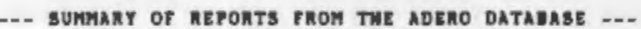

DATE

DESCRIPTION

WITU THE FAILURE OF THE CAMKKSHAFT IN THE LILCO DSh-1 ENGINE TO TWITATED A STRESS MKALYSIS PROGRAM VITH THE actual causes of the fatLURE.

SARSTEN, A

Knบ?

LOUzEexy, PJ

Dosir.

-THE FILLTE OF 2 TD: CRANXSHAFTS VERE RE-PEENED IY GTTAL INPMOVEKENT COMPANY, INC, AFTER ONICINAL SHOT TENING OY TDI UAS YOUND UWSATISFACTORY IN COVERAGE AND

TELEXED TO GERMANO 12-05-19

CRAKK SHAFT TORBIONAL VIEKATION ANALYS1S OF $13 / 12$ INCM CRANKSHAFT INDICATOR DIAGRAM GMOM LILCO 13112 TEST AT YOW LOAD MEASURED IN CYLIKDEA FIRING CHARACTERISTICS

\section{INCLUDES}

INERTIA LOCATION, INERTIA, AND BTIFTNESS

ONE NODED EREOEUNCT - 2377 -34 Y IR. TNO-NODED FREQUENCY $6420.11 \mathrm{~V} .1 \mathrm{M}$

THIS REPONT SUYOARIZES THE RESULTS OF INSPECTIONB,

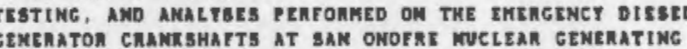
STATION UNIT 1"

03-03-75 COPY TAKEN TROM MICROPILK

$3102-32$

$01-26-99$

THE MESULTS OF FATICUE TESTS ON VARIOUS TYFES OF CRANKSHAETS ARE DESCRIUED THE TESTS VERE MADE OO

$3101-3$

12-04-79

MAKE-UP OF THIS PROPOSAL IS SUCH THAT IT CAN IE APPIEO TO VIRTUALLY ALL CRANKSHAFT CONF IGURATIOHS NOT COVERED IY THIS PMOPOSAL NUST OE SOLVED IY MEANS OF SPECIAL APPMOVAL."

SCHILLING, KV

$12-11-79$

THIS REPONT DESCRIAES A TAILURE ANALYSIS PERTONHED IN "', OM A CMANKSHAFT THAT HAD 13,132 HOURS OF

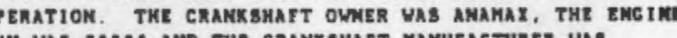
ELWOOD CITY PORGE COKPANY

FIGURE 4.7. First Page of Formal Summary Report for "ISSUE $=331$ " 
Athistios '

Tเกเ

nงT:D

Osc OATE

$\pi$

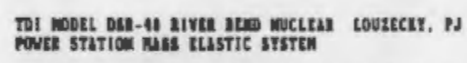

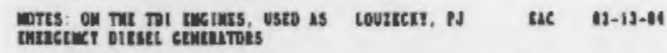

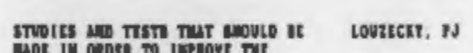
ithintulin of

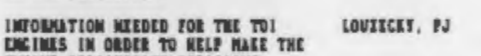

ac in-16-64

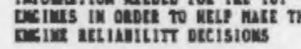

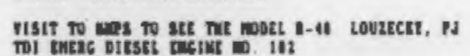

at 12-11-14

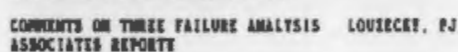

a16 $\quad$ 12-16-01

in $11-11-4$

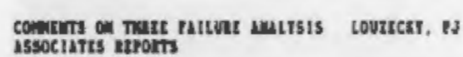

31t 13-11-14

Visit to skougun metem poven LOVzecti, BNL

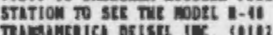

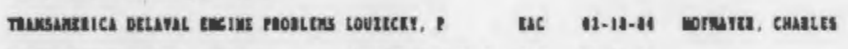

plorssional atsug - Rus

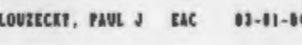

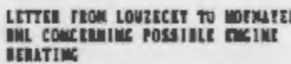

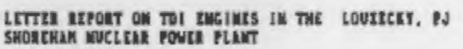

ac 13-19-14 constu, 6

ate 13-23-46

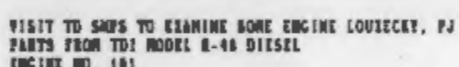

ac $13-10-31$

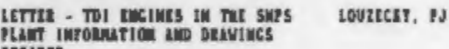

the $13-31-14$

ESIIIED

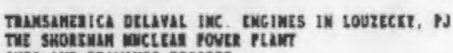
ro ate ondyimes otsitit

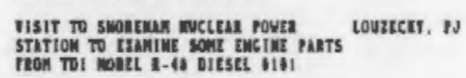

ac M-18-n Laitr, vattea y

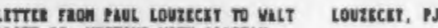

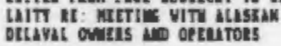

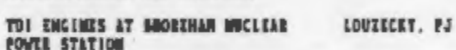

ne $13-30-14$

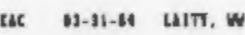

Eac $13-31-4$

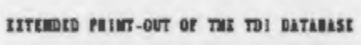

onc souct lss ot fltt

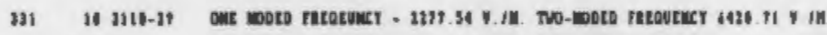

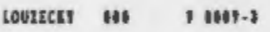

ox. IIt III

11 oIII-2s

toustext B16 12 1612-4

tousuct iss isse-4

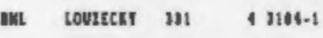

Lourtct 311 4 1314-1

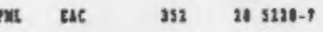

ns

$131 \quad 10316-16$

courtcri III 11 1010-1

IIt He III 1 $1061-11$

Loviecr! 3s

Lourecry 352 , s311-1

tovisck III $\quad 12$ 1112-1

ac $351 \quad 16$ sม16-1

Dessehimiok

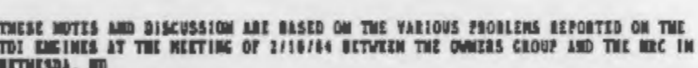

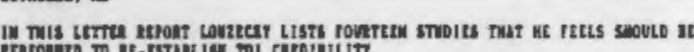

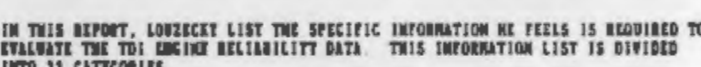

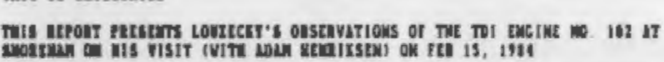

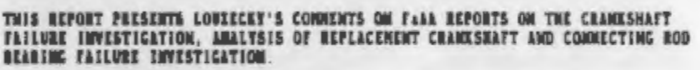

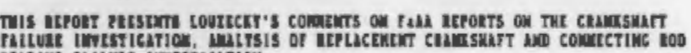

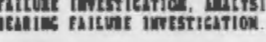

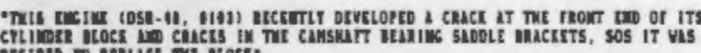

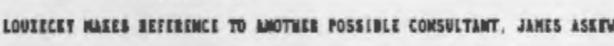

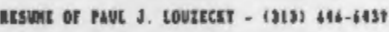

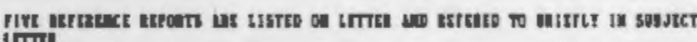

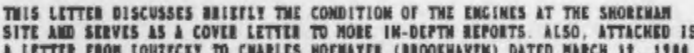

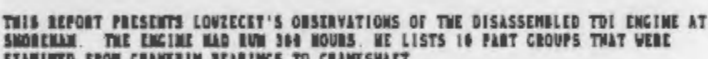

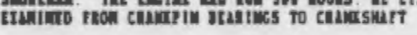

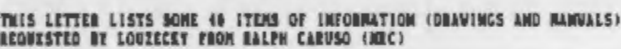

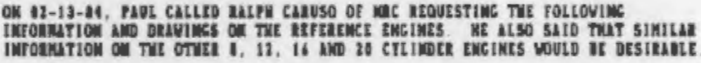

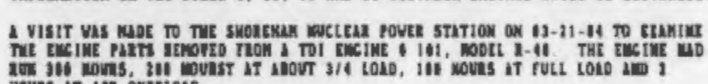
Hovis it ins ovithion

MIL 1114 16 $616-25$

tourtery 351, s114-

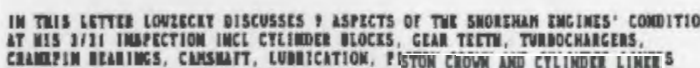

FIGURE 4.8. First Page of Expanded Report for "AUTHOR=LOUZECKY" 
The response

\section{$[4, \mathrm{SNPS}=\mathrm{T}]]$}

will provide a quick summary report listing all documents pertaining to the Shoreham Nuclear Power Station. The first page of this report is provided in Figure 4.9.

Finally, responding with

\section{[5]]}

will result in a report listing documents pertaining to the components identified in this project as having problems of potential generic applicability. The first page of the resultant report is provided in Figure 4.10 . 


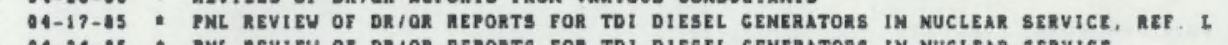

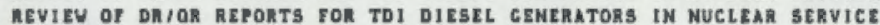

-

10-01-13: FIELD TEST OF EMENGENCY DIESEL GENERATOR 101

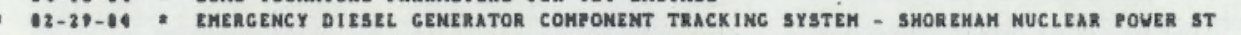

03-22-11 - TEST RESULTS YOA THE FIAST ENGINE PRODUCED FOR MODELS R-1. NV-12, RV-16 AND RV-2

:-' i

: 99-13-14: TDI DIESEL GENERATOR OUMERS CROUP RESPONSE TO PNL AND NRC OUESTIONS FILE: MTS-40

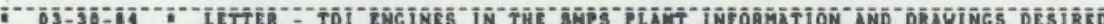

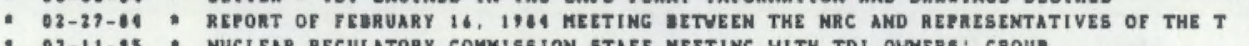

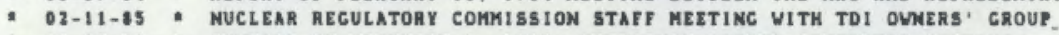

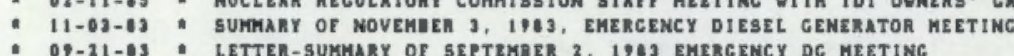

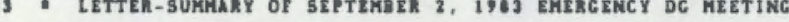

a

- 04-10-65 PML REVIEUS of DESIGK REVIEVIQUALITY REVALIDATION

O4-08-15: INFORHATION NERO

O4-17-65: DR/OR REVIEUs

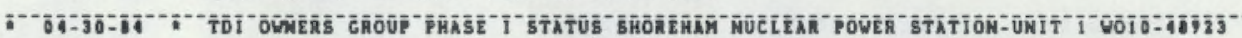

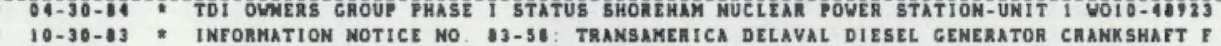

: O9-07-14:" ACCOMODATIONS AND GENERAL INFOMMATION FOR TRIP TO LONG ISLAND, NY

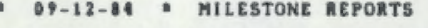

:

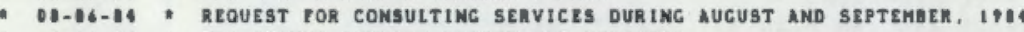

12-11-14: TDI STATUs SUMHaky REPORT FOR novemazk

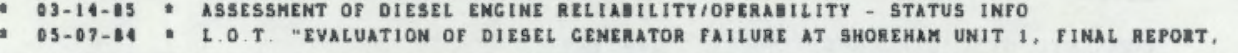

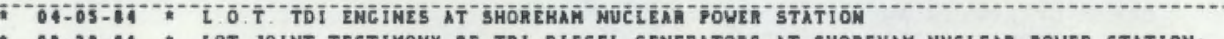

" O-29-14" " lot joint testimony he tol diesel generatons at shoreham nUClean pouer station:

O5-15-14: DEPOSITTON OF SIMON $X$. CHEN

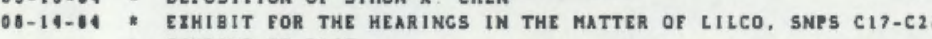

- Findinc of zact

"-

03-05-14 : REPOHT ON TRAVEL, 3/1/19 - 3/2/64 (TO BROOXHAVEN AND SHOHEHAH,

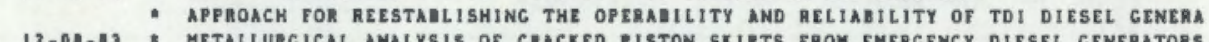

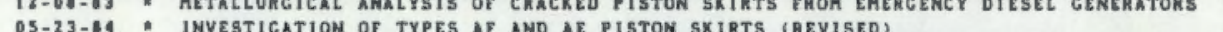

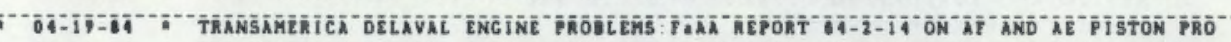

- 06-06-14 - tDi units in nuclear sehvice eValuation of aftae piston sKirts, series h ene ines

11-00-B1: LE PIOUID PENETHANT EZAMINATION REPORT tOR SHOREHAH- PISTON SKIRT

PISTON AND CONNECTING BOD UEICHT DATA FOR THE SHOREHAY ENGINE

AuTror

VENDELL, $a$

DINCzE, D

DOUECKY,

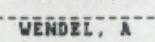

vencel, e

MUSELER, $\psi$

MatheUs, $C$.

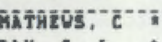

aAY, $C$. $L$.

schustea.

CUILD, D.

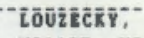

MiLLER, HE

Canuso, R

LAITY, w nessitt, J veasen, Jv

LAITY, y

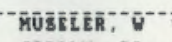
JOADAN, EL

calty.

michaels.

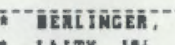

- Laity, w

gINTNEa.

dahlegen.

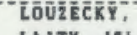

Laity, w

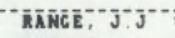
DINGEE, DA

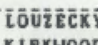

KIRKNOOd.

Mathens.

mar, cl

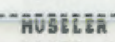

LAITY. V.W

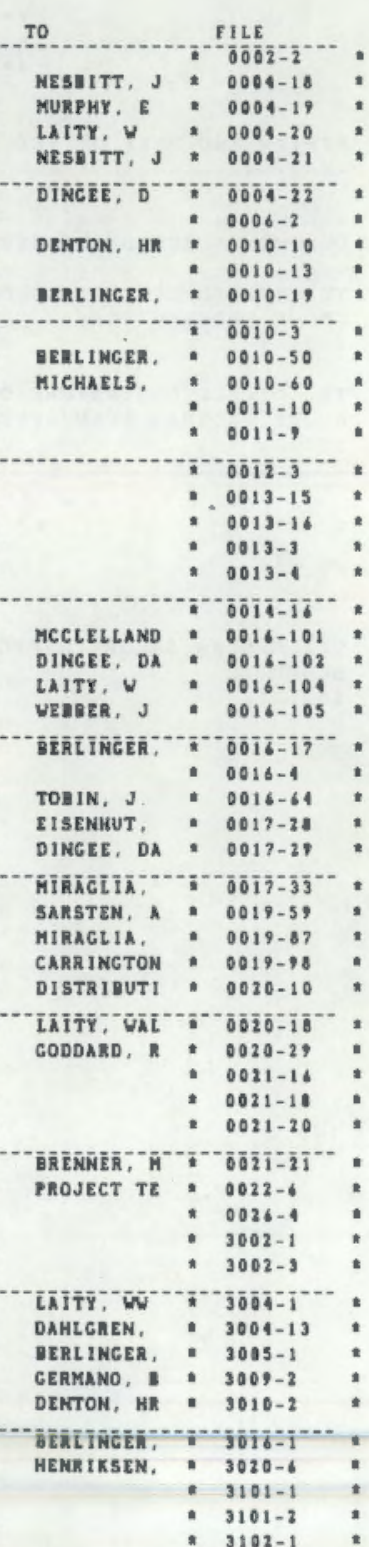

FIGURE 4.9. First Page of Quick Summary Report for "SNPS=T" 


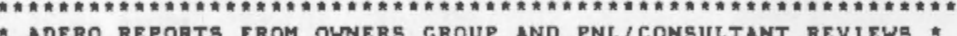

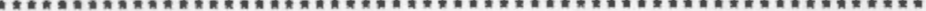

REVIEU AND PREP OF TER FOR EVAL OF OG PROGRAM PLAN - 862320

\begin{tabular}{|c|c|c|c|c|c|}
\hline DOCUMENTS REC'D FOR REVIEW & DATE REC & PNL AND NAC REVIEWS & DATE & INDIV REVIEUS/TRIP REPORTS & DATE \\
\hline $\begin{array}{l}\text { TDI DIESEL CENERATORS OUNERS } \\
\text { GROUP PROGRAM PLAM } \\
2001-1\end{array}$ & $\begin{array}{l}03-05-84 \\
\text { oc }\end{array}$ & & & & \\
\hline \multirow[t]{2}{*}{$\begin{array}{l}\text { TDI DIESEL CENERATORS OWNERS } \\
\text { CROUP PROGRAM PLAN APPENDICES } \\
2001-2\end{array}$} & $\begin{array}{l}03-03-104 \\
\text { OG }\end{array}$ & & & & \\
\hline & & $\begin{array}{l}\text { CONTENT OF OUNERS GROUP } \\
\text { REPORTS ON GENERIC } \\
\text { PROBLEMS-DIESEL ENGINE } \\
\text { OPERABILITY/RELIABILITY } \\
2003-4\end{array}$ & LATti, in & & \\
\hline \multirow[t]{7}{*}{$\begin{array}{l}\text { TDI OUNERS GROUP INSPECTION } \\
\text { SCHEDULE } \\
2009-1\end{array}$} & $\begin{array}{l}05-01-64 \\
\text { RAY, CL }\end{array}$ & & & & \\
\hline & & $\begin{array}{l}\text { TDI DIESEL ENGINE PROJECT } \\
\text { INITIAL REVIEU AND EVALUATION } \\
\text { OF OG PLAN } \\
2003-5\end{array}$ & $\begin{array}{l}05-07-04 \\
\text { LAITY, WN }\end{array}$ & & \\
\hline & & $\begin{array}{l}\text { DRAFT-AEVIEU AND EVALUATION } \\
\text { OE TDI DIESEL GENERATOR } \\
\text { OUNERS. GROUP PROGRAM PLAN } \\
2003-1\end{array}$ & $\begin{array}{l}\text { 05-11-04 } \\
\text { LAITY, WW }\end{array}$ & & \\
\hline & & $\begin{array}{l}\text { COMMENTS OF C DERLINGER ON } \\
\text { DRAFT OF REVIEW AND } \\
\text { EVALUATION OF TDD DIELEL GEN } \\
\text { OC PROGRAM PLAN } \\
2004-3\end{array}$ & $\begin{array}{l}06-01-84 \\
\text { BERLINGER }\end{array}$ & & \\
\hline & & $\begin{array}{l}\text { STATE COMMENTS ON PNL'S } \\
\text { REVIEU AND EVALUATIONOF TDI } \\
\text { DC OC PROGRAM PLAN } \\
2010-1\end{array}$ & $\begin{array}{l}\text { O6-15-84 } \\
\text { BERLINGER }\end{array}$ & & \\
\hline & & $\begin{array}{l}\text { REVIEW AND EVALUATION OF TDI } \\
\text { DIESEL GENERATOR OUNERS } \\
\text { GROUP PROGRAM PLAN } \\
2003-2\end{array}$ & $\begin{array}{l}\text { 07-00-84E } \\
\text { PNL }\end{array}$ & & \\
\hline & & 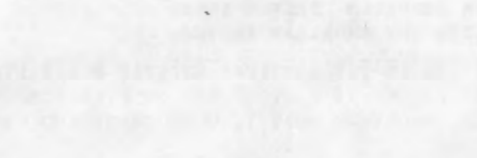 & & $\begin{array}{l}\text { KIRKWOOD'S COMMENTS ON REVIEW } \\
\text { AND EVAL OF TDI DIESEL } \\
\text { GENERATOR OWNERS' GROUP } \\
\text { PROGRAM PLAN (DRAET) } \\
2004-2\end{array}$ & $\begin{array}{l}08-06-84 \\
\text { KIRKWOOD. }\end{array}$ \\
\hline
\end{tabular}

FIGURE 4.10. First Page of Generic Issue Tracker Report 


\subsection{2 dBase III Reports}

In addition to the project-specific reporting formats, dBase III includes an easy-to-use report-generating utility that allows the user to generate custom reports from any dBase III database. This report generator is entirely menu-driven and must be used outside the document database main program (DG.PRG).

To enter this report-generating utility, enter a [6] from the Main Menu. The system will respond with the dBase III standard dot (.) prompt. Enter [MODIFY REPORT filename]], where filename is a user-specified name for the report format to be generated. This name must be less than 8 characters in length. Follow the instructions in this utility to design a custom reporting format. When the desired reporting format is complete, depress "Ctrl" and "W" simultaneously. Enter [REPORT FORM filename TO PRINT]] to begin printing the entered report.
Manual. However, the report formats provided in the document database system should provide sufficient flexibility for any projected reporting requirements.

\subsection{MAINTAINING THE DOCUMENT DATABASE}

Although the document database is expected to remain relatively static, the utility programs that were used to facilitate entering and editing data are provided. These utilities and their use are described in the subsections that follow.

\subsubsection{Adding Records}

Entering data on documents to be added to the document database is accomplished using the ADDREC procedure. This utility will set up the screen to facilitate data input, list some of the most common abbreviations, and assign a file number to the document based on the ISSUE and DOC_TYP codes.

The specific features of this report generator and detailed instructions for its use are documented in the dBase III User's 
To add a record, enter a [3] from the Main Menu. (Note: If the system displays the ABase III standard dot (.) prompt, enter $[D 0[G]]$ to get back into the main program.)

The system will then set up the screen for inputting the requisite data. When entering data, special cursor control and inputting functions may be used as described in the following paragraphs.
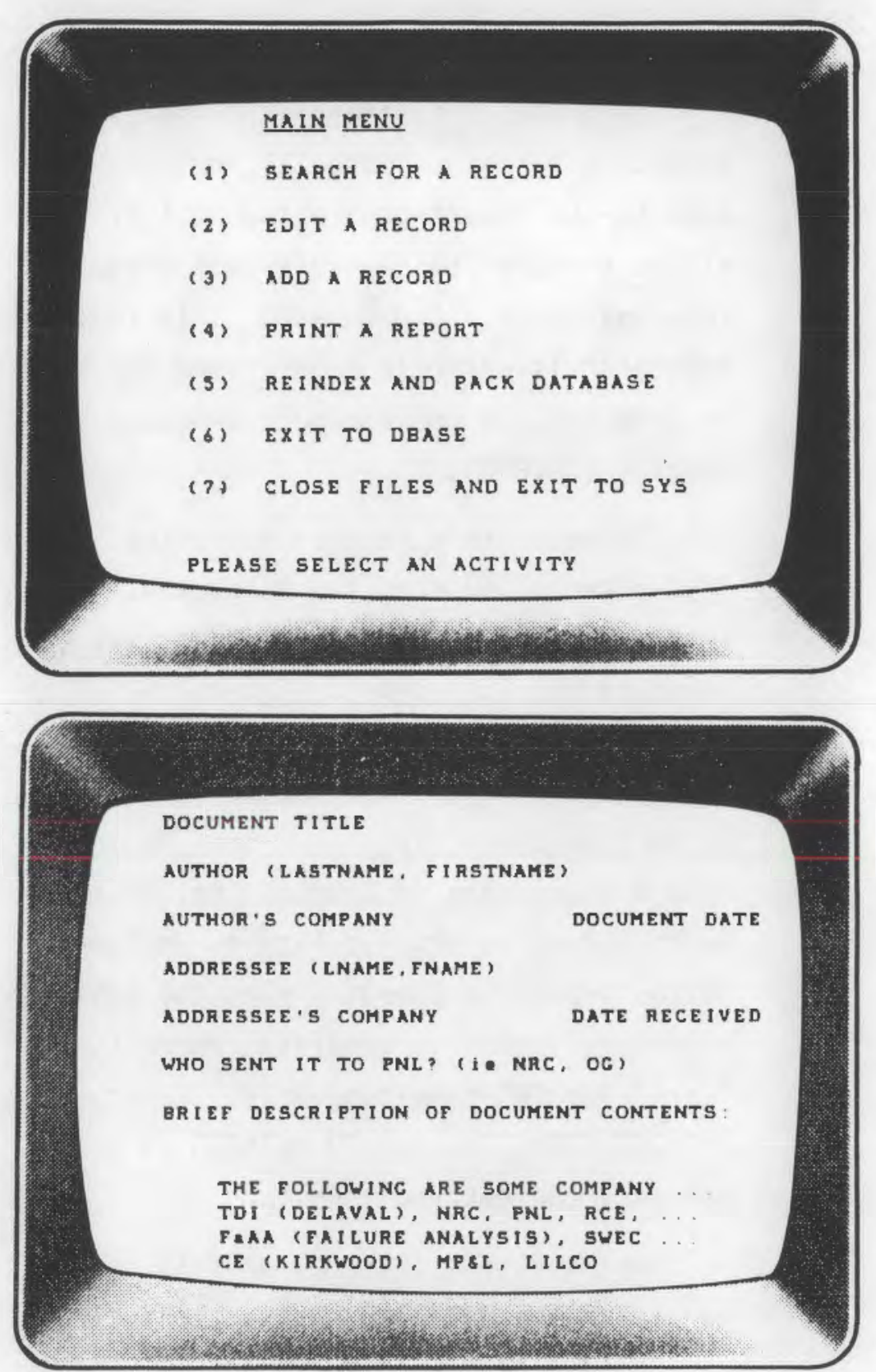
Cursor control keys on the numeric keypad (up arrow, down arrow, left arrow, and right arrow) may be used.

The left arrow moves the cursor one space to the left; the right arrow moves the cursor one space to the right. The up arrow moves the cursor to the previous field, and the down arrow moves the cursor to the subsequent field. If depressing these keys causes numbers to be displayed on the screen, then depress the "Num Lock" key once.

Certain keys depressed while the "Ctrl" key is depressed also provide special functions to facilitate data entry. In the following discussion, a "^" preceding a letter is used to indicate that the specified key should be depressed while the "Ctrl" key is depressed (similar to the shift key).

Depressing ^ $S$ will function the same as the left arrow key. Similarly, ^D, $\wedge E$, and $\wedge x$ will emulate the right arrow, up arrow, and down arrow, respectively.
In addition, the $\wedge A$ will move the cursor to the beginning of the previous word, and $\wedge F$ will move the cursor to the beginning of the next word.

The ${ }^{\wedge} G$ will delete the character under the cursor, the ^ $T$ will delete the character under the cursor and all subsequent characters in the same word, and the ${ }^{\wedge} Y$ will delete the character under the cursor and all subsequent characters in the field.

The $\wedge U$ will toggle a tag for deleting the entire record, although the record will not be purged from the database until a Pack of the database is performed. Packing the database will be discussed in Section 4.3.3.

The $\wedge v$ will toggle input between overwriting and insertion modes. If the current input mode is toggled to insertion, then the words INSERT ON will be displayed at the top of the screen. 
When the desired information is input on the current screen, enter $a^{\wedge} W$. A sample entry is shown.

The remaining fields in the record will now be displayed for data entry, with the document title displayed at the top of the screen. As discussed earlier, all documents should include a non-zero DOC_TYP code. If the ISSUE code is left blank, it will default to zero.
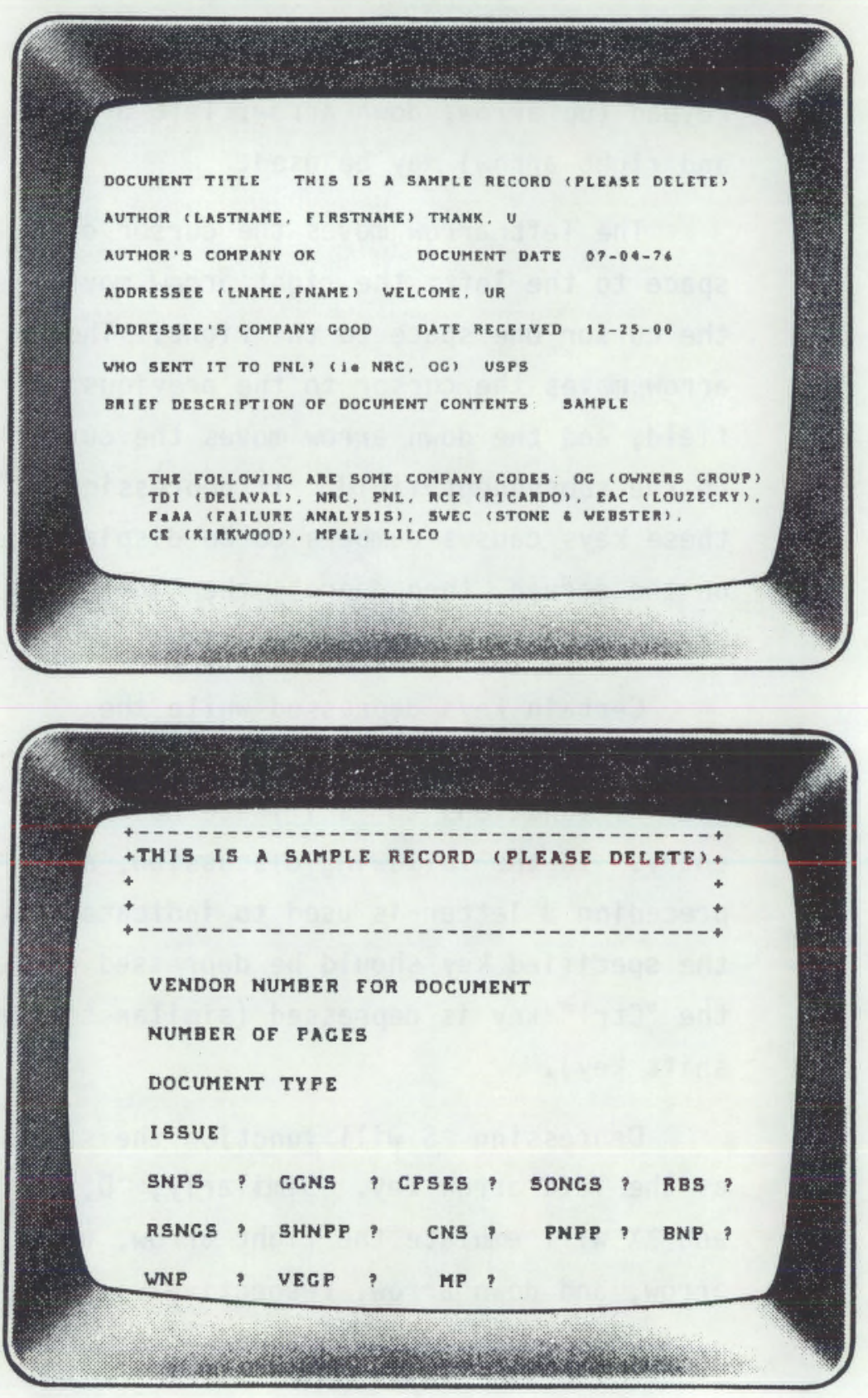

4.38 
If the document being added to the database pertains to specific reactor sites, then the appropriate site fields (e.g., SNPS, GGNS) should be set to true by entering a $[T]$ in the appropriate field.

When the information has been entered, depress $\wedge$ W. Sample data for the second half of the record are shown. Note the issue code and document type code. These codes will be used to generate the file number.

After a few seconds, the file number assigned by the system will be displayed on the screen. In our sample entry, a DOC_TYP code of 88 and ISSUE code of 999 were used. This results in a file number 9988-1. The file number assigned by the system should always be copied to the top right corner of the entered document (hard copy) to allow for correct filing. The system will also ask if you wish to add another document. A [Y] response will result in a new blank record appearing on the screen; an [N] response will return you to the Main Menu.
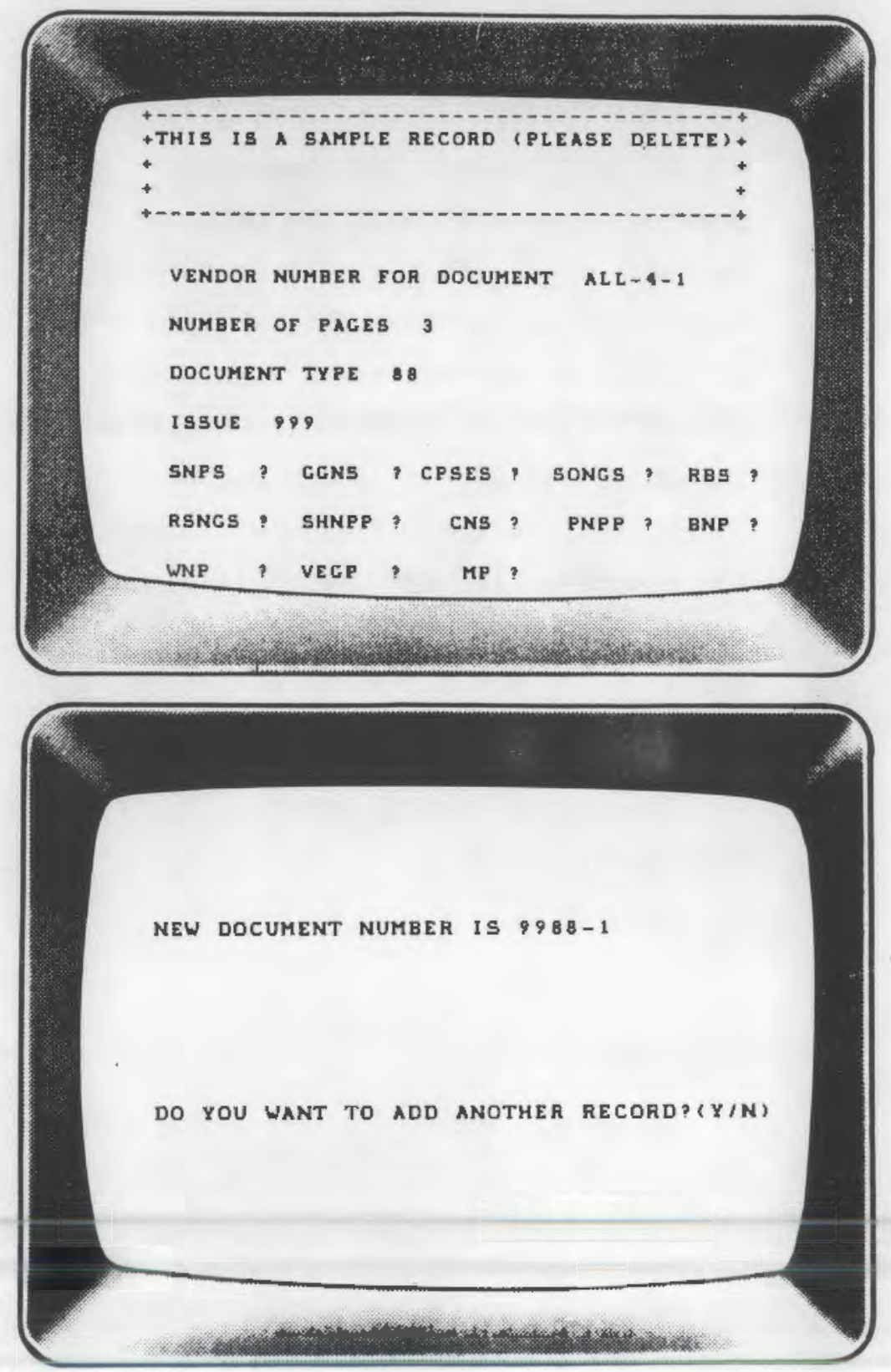


\subsubsection{Editing Records}

The EDITREC utility will allow you to edit records that have been previously entered into the document database. As with the edit feature in the Speed Search mode, this utility will allow you to correct minor errors such as misspellings. In addition, corrections to the ISSUE and DOC_TYP codes may be made. Corrections in these fields will change the document FILE_NUM. When file number changes are made, the new file number should be recorded IMMEDIATELY on the hard copy of the reference document.

To edit a record, enter a [2] from the Main Menu.

Warning: Changing the file number in the database without following up with a corresponding change on the document hard copy file number is tantamount to losing the document.

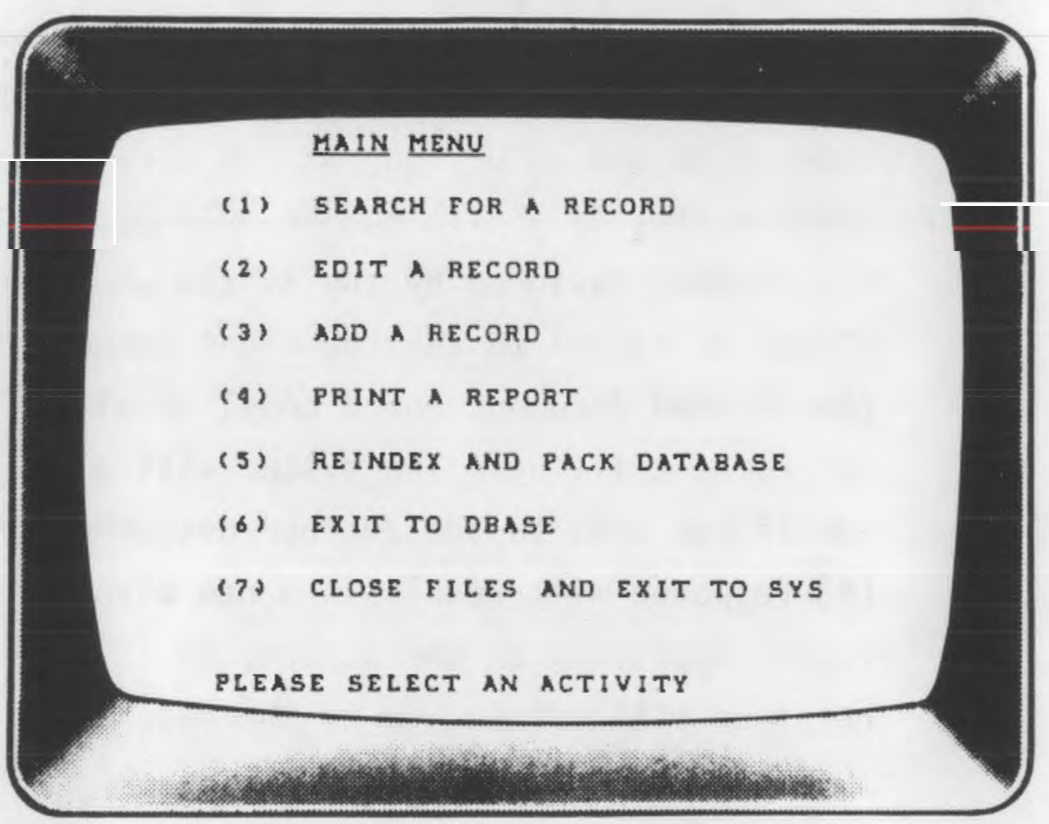


The system will request the file number of the document to be edited. The exact file number must be known. If the file number is not known, enter an [R]] to return to the Main Menu. Any of the search modes may be used to find the file number of the document to be edited.

To edit a record, enter its file number followed by a return. As an example, enter [9988-1]]. All information in the database regarding the requested document will be displayed on the screen, with the exception of the file number. Recall that the file number will be assigned by the system. If no changes are made to the DOC_TYP or ISSUE codes, then the FILE_NUM will remain unchanged.
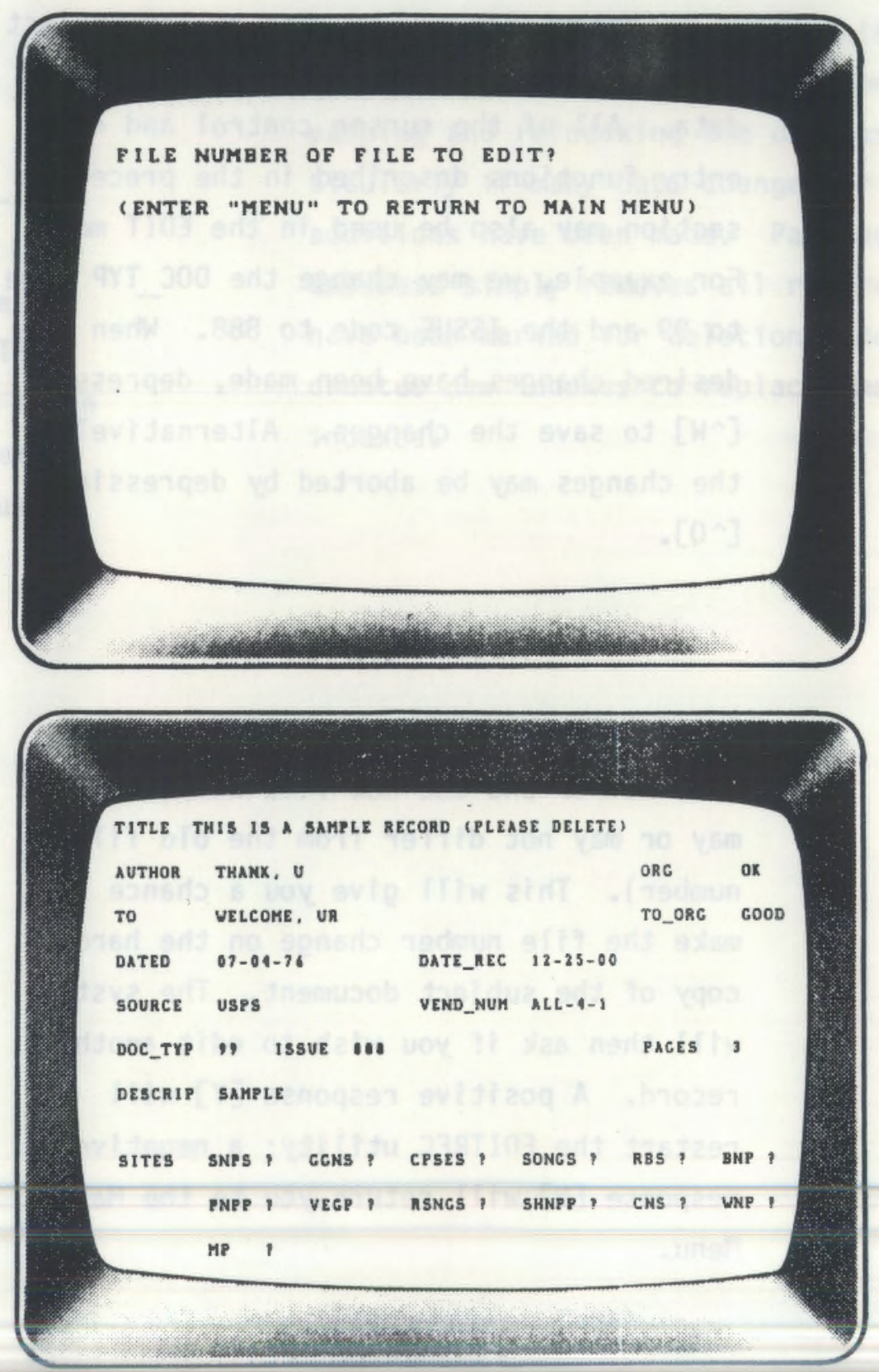
To find out how many records are in the CHANGES database, enter [DISPLAY STRUCTURE]]. Displayed on the screen will be the name of the database (CHANGES.dbf), the number of records in the database (361), the date of the last update $(06 / 20 / 85)$, and a list of the fields that make up the database.

If you want to list all of the records in CHANGES on the screen, enter [DISPLAY ALL]]. If you want only the most recent $n$ records, first calculate the starting record number ( $s=$ number of records $-n+$ 1), then enter [GOTO s]] and [OISPLAY NEXT n]]. For example, to display the last

10 records $(s=361-10+1=352)$, enter [GOTO 352]], [DISPLAY NEXT 10]].
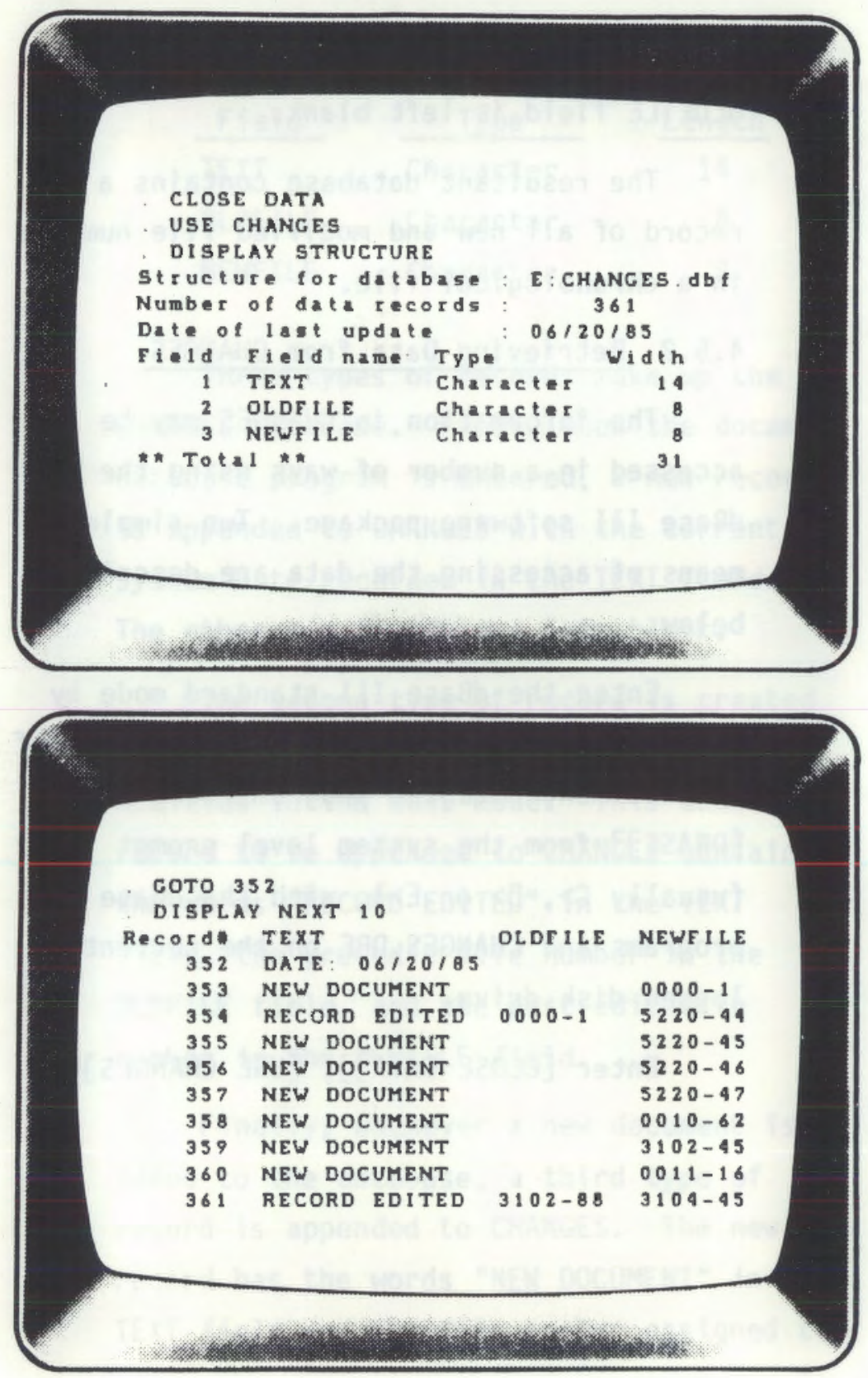

D 
For printer output, the command format is very similar. Enter [LIST ALL TO

PRINT]] to print all records. Enter [GOTO

$\mathrm{s}$ ]] and [LIST NEXT n]] to print the last $n$ records.

To return to the document database main program, enter [DO DG]]. Alterna-

tively, to exit from dBase III, enter [QUIT]]. 
1

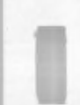

II

I

D

प

a

0

प

【

I

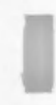

[

口

॥ 


\subsection{DRAWING DATABASE FEATURES AND USER'S INSTRUCTIONS}

The structure and features of the drawing database are described in this section. The description is followed by explanatory notes and examples that show how to use the database to find component drawings.

It is important to note that the drawing database is completely separate from the document database. The instructions in Section 4.0 for searching, adding, editing, and reporting on documents will not function with the drawing database due to basic structural differences between the databases. An elaborate package for manipulating the drawing database was deemed inappropriate, based on the projected frequency of database use. The static nature of the database (no new drawings are expected to be added) also indicated little need for sophisticated data manipulation routines.
To use the drawing database, the files listed in Table 5.1 should reside on the currently logged disk drive.(a)

TABLE 5.1. Computer Files Needed for the Drawing Database
dBase III and System Files
DBASE.EXE
DBASE.OVL
CONFIG.SYS
CONFIG.DB

Drawing Database Files

\subsection{DRAWING DATABASE STRUCTURE}

The drawing database structure includes only the drawing title, drawing number, and an assigned file number. These fields are described in Table 5.2.

(a) The drawing database is small enough to use from a floppy disk drive. Refer to the "SET DEFAULT T0" command in the dBase III User's Manual if you want to use the database from a floppy disk drive. 
TABLE 5.2. Drawing Database Structure

\begin{tabular}{|c|c|c|}
\hline Field & Type & Length \\
\hline TITLE & Character & 55 \\
\hline NUMBER & Character & 20 \\
\hline FILE_NUM & Character & 7 \\
\hline
\end{tabular}

Experience has shown that the database in its current form can be used effectively for finding specific drawings with minimal manual search requirements.

\subsection{SEARCHING THE DRAWING DATABASE}

The simple structure of the drawing database makes searches of the database straightforward. The files listed in Table 5.1 should reside in the current directory of the hard disk drive. Enter the command [DBASE]], followed by [USE DGDRAW]]. You are now ready to search the DGDRAW database.

\subsubsection{General Form of the Search Commands}

To find specific drawings, you may search either the TITLE field or the NUMBER field for known data, and find the corresponding file number(s). The following discussion describes two dBase III substring search commands as they may be applied to the drawing database. The first substring search command is used to direct information to the screen; the second search command is used to print out the desired information.

To display the file information on the screen, the command format is

\section{DISPLAY OFF fields FOR 'string'\$field}

Here, fields may he any combination of the fields TITLE, NUMBER, and FILE NUM, delimited with commas. If fields is not specified, then all three fields will be output. string is the information known about the desired drawing(s), usually the part number or some part of the drawing title. field is the one field that would contain the input atring. A sample command would be

\section{DISPLAY OFF TITLE,FILE NUM}

FOR 'PISTON'\$TITLE 
Note that string should always be input in all capital letters.

If more records match the input search condition than would conveniently fit on the screen, then the output will pause when the screen is filled and display the message "Press any key to continue...". Depressing any key will cause subsequent records to be similarly displayed.

To 1 ist the requested information on the printer, the command format is

\section{LIST OFF fields FOR}

'string'\$field TO PRINT

The fields, string, and field parameters are the same as described above. An example of this command is

LIST OFF TITLE, NUMBER, FILE NUM FOR

'CAMSH'\$TITLE TO PRINT

\subsubsection{Examples of Drawing Database Searches}

One caveat regarding these substring search commands is in order. When using these commands, be aware that the drawing titles may contain abbreviations, and that dBase III will look for the exact substring specified in otring. You must be careful, therefore, not to overspecify string in the search commands.

For example, connecting rods are frequently referred to as conn rods. The command

\section{DISPLAY OFF TITLE, FILE NUM}

FOR 'CONNECTING'\$TITLE

will not find drawings using an abbreviation for "connecting". An alternative command is 
DISPLAY OFF TITLE,FILE NUM

FOR 'CONN'\$TITLE

This command will find all drawings with 'CONN' in the title, even if 'CONN' is part of another word (i.e., CONNECTING).
Examples of these commands are listed in Table 5.3. Samples of the output corresponding to these commands are presented in Figures 5.1 through $\mathbf{5 . 4}$.

TABLE 5.3. Examples of Drawing Database Search Commands

$\begin{array}{lll}\frac{\text { Command }}{\text { DISPLAY OFF TITLE,FILE_NUM FOR 'FOUND'\$TITLE }} & & \text { Output } \\ \text { OISPLAY OFF TITLE,FILE_NUM FOR 'PIST'\$TITLE } & \text { See Figure } 5.2 \\ \text { LIST OFF TITLE,FILE_NUM FOR 'CONN'\$TITLE TO PRINT } & \text { See Figure } 5.3 \\ \text { LIST OFF FOR '345'\$NUMBER TO PRINT } & \text { See Figure } 5.4\end{array}$





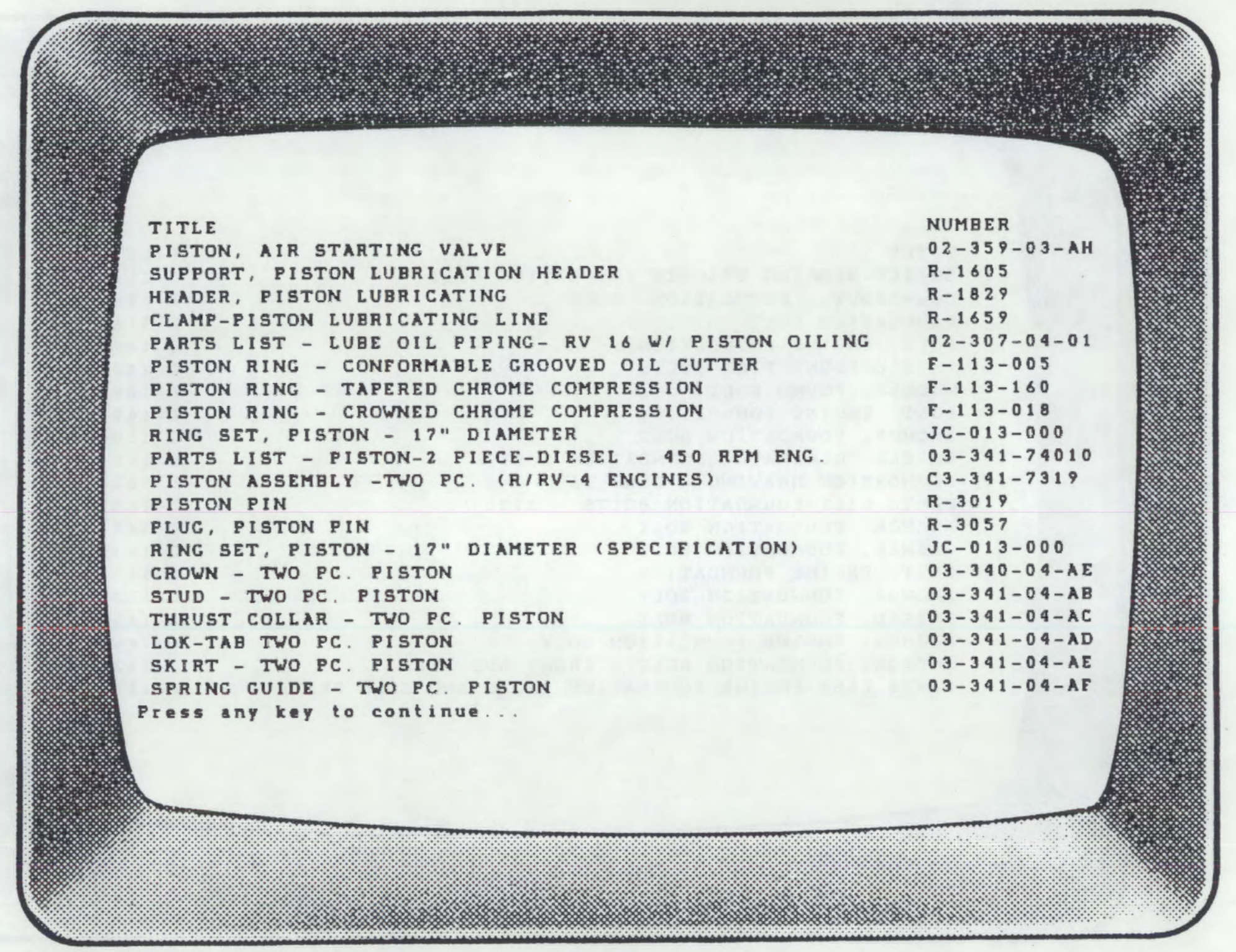

FIGURE 5.2. Sample Output Resulting from "DISPLAY OFF TITLE,FILE_NUM FOR 'PIST'\$STITLE" 

CONHECTOR, MALE 1/4P $114 T$

TUEE FITTINGS - MALE CONNECTOR

TUBE FITTINGS, MALE CONNECTOR

PIPE, CONHECTOR

TUEE FITTINGS-HALE CONNECTOR

TUBE FITTINGS-MALE CONNECTOR

FLEXIBLE CONHECTOR - AIR INTAKE (SPECIFICATIDN)

CONHECTOR - "R" S AV", EXHAUST ROCXER ARM

COMHECTOR FRONT SUMP DRAIN

TUBE FITTINCS - MALE CONNECTOR (SPECIFICATION)

TUBE FITTINGS - MALE CONNECTOR SPECIFICATION)

TUBE FITTINGS - MALE CONNECTOR

PARTS LIST - CONHECTINC ROD - 12" DIA. CAANK PINS

CONNECTING ROD AND BUSHING ASSEMBLY

CONHECTING ROD - FIMAL MACHINING

BUSHINC - COHN. ROD

BDLT - CONNECTING ROD

WASHIMG, CONK. ROD BOLT

SHELL - CONMECTING ROD BEARING - UPPER AND LOWER

CONHECTING RDD, LINK

LINX, CONM ROD ASS'Y

RING, RETAINER - CONHECTING ROD SHELL

SHELL, CDHN ROD BEARING - UPPER AND LOWER

BUSHING, CONHECTINC ROO BOX

BOLT, CONNECTING ROD

BOLT, CONNECTING ROD

DOVEL, MASTER ROD TO CONH. ROD BOX

CONM. ROD MASTER

MASTER ROD AND CONN. ROD BOZ

MASTER ROD E CONN ROD BOX ASSEMBLY

PISTON \& CONN. ROD ASSY. (13" DIA CRANKPINS)

PARTS LIST-PISTON : CONH ROD-150 ENG. RPM-13" PINS

E. . T. COMPRESSION CONHECTORS (SPECIFICATION)

CORD GRIP CONHECTORS (SPECIFICATIOH)

OIL-TIGHT THREE WIRE CONHECTOR (SPECIFICATIDN)

LIOUID-TIGHT CONDUIT CONNECTORS (SPECIFICATION)

CORD GRIP COHHECTOR

LIQUID-TIGHT CONDUIT CONNECTORS (SPECIFICATIOH)

CONNECTOR - AUY F. OIL PIPE TD TUBING

TUEE FITTINGS - MALE CONNECTOR (SPECIFICATIOH)

TUBE FITTING - MALE CONHECTOR (SWAGELOX)

CONHECTOR, HOSE EITTINC

FLEXIBLE CONHECTOR, AIR INTAKE (AIR MAZE

CONNECTOR LUBE DIL SUMP DRAIN

TUBE FITTINC BULKHEAD FEMALE CONNECTOR

MOUNTING BLOCK 12 PORT CONNECTOR

$0-017$

$0-0176$

$0-0309$

$0-0386$

D- 0401

$D-0532$

D- 0585

D- 0634

D- 0849

$D-0253$

D- 0934

$0-0973$

$0-1098$

D-1048

$D-1049$

D- 1050

D-1051

D-1052

D-1054

D- 1055

D-1227

$0-1227$

D-1228

$0-1229$

D -1230

D-1233

D-1234

D-1237

D-123,

D-1241

D-1242

D-1293

$D-1243$

$0-1294$

$D-1245$

D-1318

D-1319

$D-1321$

D-1324

D-1327

$D-1341$

D-1383

$0-1396$

$D-1396$

D-1581

D- 1658

D-1676

D-1681

D-1814

D-1854

TUBE FITTINGS, MALE CONNECTOR 
TITLE

TAPPET-INTAKE AND EXHAUST

BASE ASSEMBLY-FUEL PUMP

MOLLER, CAM

BUSHING, ROLLE

BUSHING PIN

PIK, ROLLER

TAPPET, FUEL

TAPPET ASSEMBLY FUEL

GUIDE-FUEL TAPPET

GUIDE ASSY -FUEL TAPPET

ROLLER, CAM

BUSHING-ROLLER

BUSHING-PIN

BUSHING-PIN

PIN, ROLLER
TAPPET ASSEMBLY INLET AND EXHAUST

GUIDE-TAPPET CLUSTEA

TAPPET AND GUIDE ASSEMBLY INTAXE AND EXHAUST

TAPPET AND GUIDE ASSEMBLY

PARTS LIST-TAPPETS AND GUIDES-IN. EXH. AND FUEL

STUD-FUEL PUMP BASE-RV

VENT TUBING - EUEL PUMP BASE

VENT TUBTH -

BASE ASSEMELY - FUEL PUMP

GUIDE, FUEL TAPPET

GUIDE XSSEMBLY - FUEL TAPPET

GUIDE-TAPPET CLUSTER, WIO AIR START

TAPPET AND GUIDE ASS'Y INTAKE-EXHAUST

TAPPET AND GUIDE ASSY, INTAKE, EXHAUST, AIR AND FUE

PARTS LIST-TAPPETS AND GUIDES-INLET-EXHAUST FUEL
NUMBER

$08-345-03-A J$

$03-345-1821$

$02-345-01-08$

$02-345-01-0 R$

$02-345-01-0 E$

$02-345-03-A B$

$02-395-03-A E$

$02-345-2462$

O3-345-02-AA

$02-345-2463$

$08-345-03-A E$

$08-345-03-A B$

$08-342-03-A$

$08-345-03-A$

$02-345-1809$

$03-345-02-A C$

$02-345-179$

$03-345-02$

$03-345-02-02$

02-345-01-0

$02-345-03-A F$

$02-345-3443$

$02-345-03-A$

$02-345-03-40$

$02-345-1227$

$02-345-03-A$

$02-345-1225$

02-345-03

$02-345-03-02$
FILE_NUM

$0-0020$

D- 0026

D-0027

D-0028

$0-0039$

$0-0030$

$0-0036$

$0-0037$

$0-0038$

D-003,

$D-0041$

D-0042

D-0043

D-0044

D-0045

$D-1411$

$D-1412$

D-1414

$D-1415$

D-1416

$0-1416$

$0-1418$

0

D-1419

D-1420

FIGURE 5.4. Sample Output Resulting From "LIST OFF FOR '345'\$NUMBER TO PRINT" 
APPENDIX A

DOCUMENT DATABASE MANIPULATION PROGRAMS LISTING 
* program listing for the document database - dG. def

* MaIN PROGRAM - DG. PAG

PROCEDURES - - DGPROC. PRG

FORMAT FILES -- DGSTD.FMT, DCTHR.FMT, DGFOR.FHT

SET PROCEDURE TO DGPROC

* the folloning statements set various dease features

SET HEADING OFE

SET SAFETY OFE

SET DEVICE TO SCREEN

HELEASE ALL

SET TALK OFF

CLEAR

* THE DATABASE FILE NAME IS DG

* four indexes aAe used - file, title, oate, and author

* THE FOAMAT FILES SIMPLY ESTABLISH SCREEN FORMAT FOR RECORD DISPLAYS

USE DG

SET INDEX TO FILE, TITLE,DATE, AUTHDR

SET FORMAT TO DCSTD

SELECT B

* Changes is a supplemental database used to record file number changes USE CHANGES

GOTO BOTT

STORE DTOC(DATE()) TO DCHECK

IF SUBSTA(TEXT,7,8)()DCHECK

APPEND BLANK

REPLACE TEXT WITH 'DATE: '+DTOC(DATE())

ENDIF

SELECT A

DO WHILE.T

SET COLOR TO GR+/B,W/R, C

* - white the main menu to scheen

CLEAR

" 6, ZU SAY : Haín MENU'

E 3,20 5AY ' $\ldots \ldots$...'

e 5, 15 SAY '(1) SEARCH FOA A RECOAD' 
e 7.15 SAY '(2) EDIT A RECORD'

Q 9,15 SAY '(3) ADD A NEV RECORD'

e 11,15 SAY '(4) PRINT A REPORT'

E 13,15 SAY '(5) REINDEX AND PACK DATABASE'

e 15,15 SAY' (6) EXIT TO DEASE"

E 17,15 SAY '(7) CLOSE FILES AND EXIT TO SYSTEM

e 20,15 SAY 'PleAse SELECT AN ACTIVITY '

e 23,1 SAY,

WAT ' ' TO ACT

Q 22,0 $5 A Y$

DO CASE

CASE ACT $=$ ' 1

e 5,9 SAY '.--1 '

e 20,1 SAY'.

STORE 1 TO CTR

DO UHILE CTR 15

STORE $1+$ CTR TO CTR

ENDDO

DO SEARCH

CASE ACT $=12$

Q 7,9 SAY ' $\ldots-$ )'

e 20,1 SAY 1

STORE 1 TO CTR

DO WHILE CTRS15

STORE $1+$ CTR TO CTR

ENDDO

DO EDITREC

CASE ACT $=3$ '

-9,9 SAY '.--$)$

- 20,1 SAY' '

STORE 1 TO CTR

DO VHILE CTR 15

STORE 1+CTR TO CTA

ENDDO 
DO ADDREC

CASE $A C T=14$ '

e 11,9 SAY '----)'

e 20,1 SAY

STORE 1 TO CTR

DO UHILE CTR 15 STORE 1+CTR TO CTR

ENDDO

DO REPT

\section{CASE ACT $=$ ' 5 '}

e 13,9 SAY'--- 1 .

Q 20,1 SAY.

STORE 1 TO CTR

DO WHILE CTA 15

STORE $1+C T R$ TO CTR

ENDDO

CLEAR

C 15,10 SAY 'ARE YOU SURE?(Y/N)'

UAIT ' ' TO SURE

I F UPPER (SURE) $={ }^{\prime} T$ ' , OR. UPPER (SURE) $={ }^{\prime} Y{ }^{\prime}$

DO INDEXER

ENDIF UPPER (SURE)

CASE ACT $=161$

e 15,9 SAY ' - - $)$

e 20,1 SAY' '

STORE 1 TO CTR

DO UHILE CTR 15

STORE $1+$ CTR TO CTR

A. 3 
ENDDO

CLEAR

Q 10,8 SAY , '

? 'FILE NUMBER CHANGES ARE RECORDED IN CHANGES. OBF'

STORE ' $R$ ' TO PK

$\star$

RELEASE PAN, CTA, ACT, CHGEIL 2 , TEST, COUNT, MAIN, REINO, PK

C 16, 4 SAY '

SET ESCAPE ON

SET PROCEDURE TO

RETURN

CASE ACT $=\cdot 7 \cdot$

(17,9 SAY ' - - - )

e 20,1 SAY'.

STORE 1 TO CTR

DO WHILE CTR 15

STORE 1+CTR TO CTR

ENDDO

CLEAR

E 13,B SAY' '

? 'FILE NUMBER CHANGES ARE RECORDED IN EILE CHANCES DBF'

RELEASE PAN, CTR, ACT, MAIN, TEST, REIND, COUNT

Q 20,1 SAY ' '

USE

SET ALTERNATE TO

QUIT

\section{OTHERUISE}

e 22,1 SAY 'ILLECAL ENTRY - ENTER 1, 2, 3, 4, 5, 6, OR 7

STORE 1 TO PAN

DO WHILE PAN 30

STORE PAN+1 TO PAN

ENDDO 
ENDDO

USE

USE DG INDEX FILE

SET ESCAPE ON

SET PROCEDURE TO

RETURN

* THE dGPROC PRG FILE CONTAINS ALL THE PROCEDURES (SUBROUTINES)

* used for the adero document database

$*$

PROCEDURE SEARCH

$\star$

* procrah search. men

* THIS PROGRAM WILl DISPLAY a MENU

* of search options and call up the

* APPROPRIATE SUBROUTINES.

$\star$

CLEAR

SET COLOR TO $7 / 0$

STORE TO LINE

$\mathrm{R}=\mathbf{3}$

$\mathrm{C}=28$

$\mathrm{N}=\mathbf{2}$

* watte search menu to screen

e R, 28 SAY 'DOCUMENT SEARCH MENU'

e $R+1,2 B$ SAY 1 ine

$R=R+N+2$

e R, C SAY '(S) SPEED SEARCH'

$\mathbf{R}=\mathbf{R}+\mathbf{N}$

ER,C SAY '(K) KEYWORD SEARCH'

$R=R+N$

O R,C SAY '(B) BOOLEAN SEARCH'

$R=\mathbf{R}+\mathbf{N}$

C $R, C$ SAY ' $(R)$ RETURN TO MAIN MENU'

$R+2,18$ SAY L INE-LINE

SET COLOR TO ?/4 


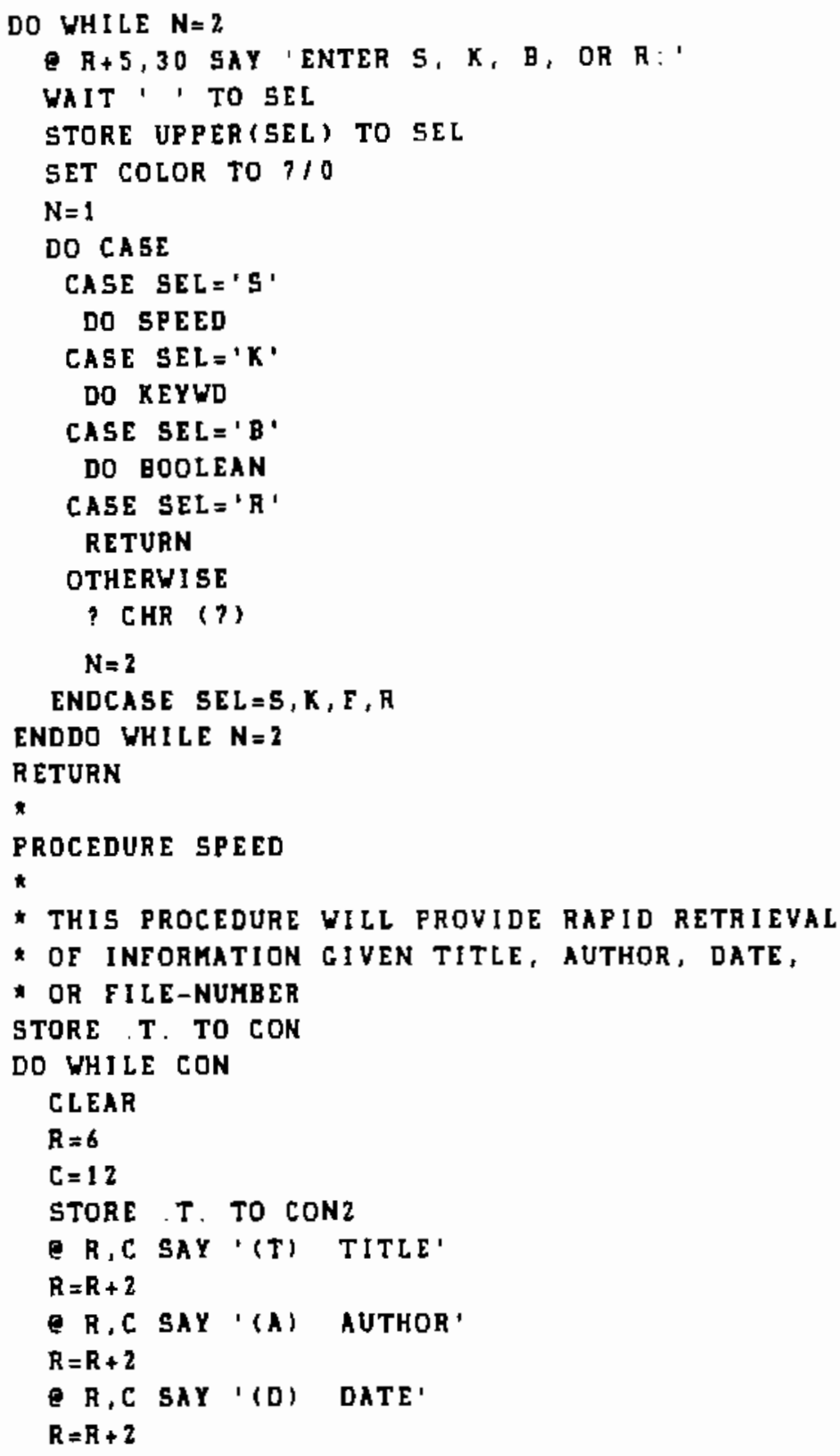




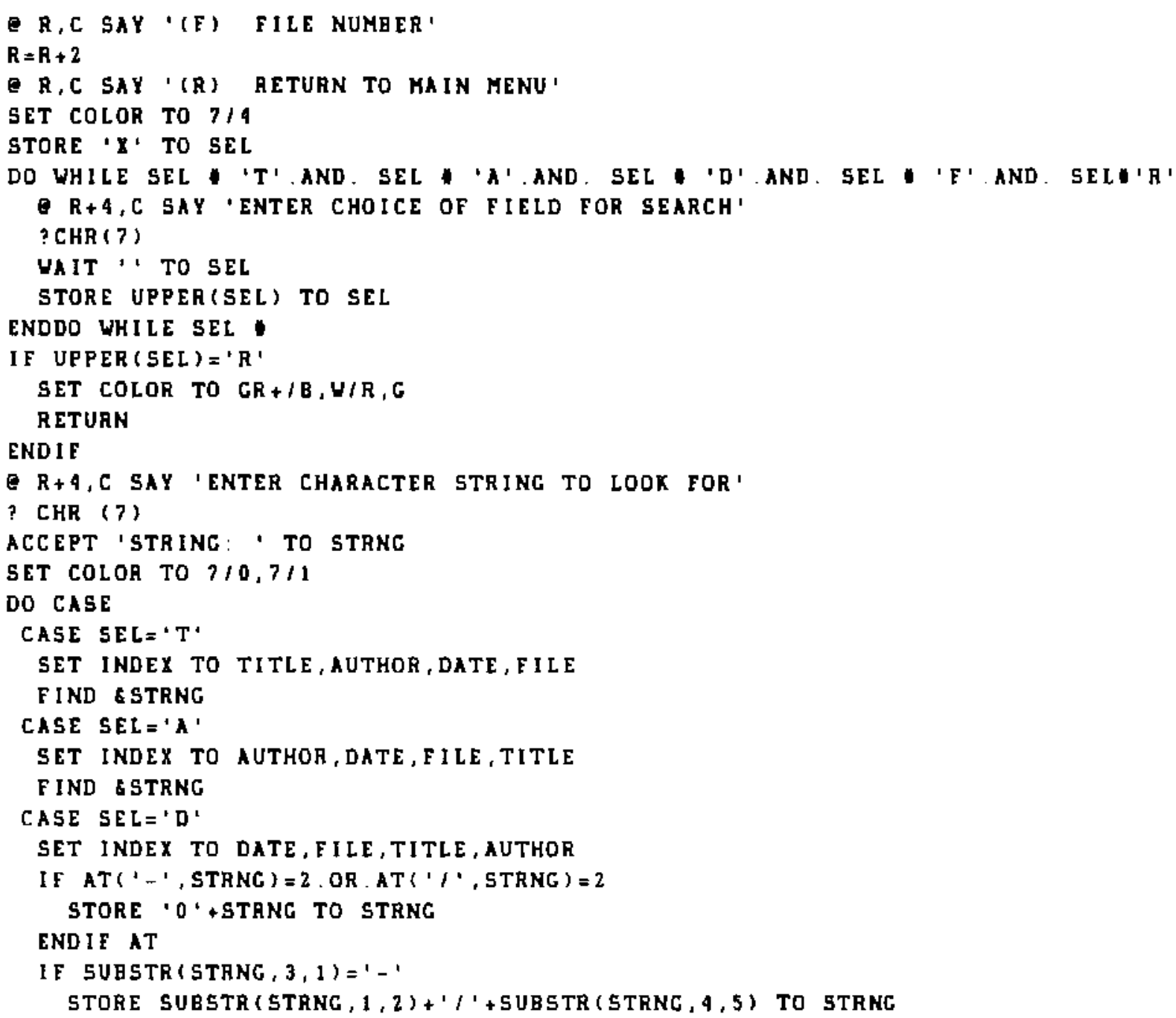


ENDIF SUBSTR(STRNG, 3,1 )

IF SUBSTR (STRNG $, 5,1)=1-1$ OR . SUBSTR (STRNG , 5, 1) $=1 / 1$

STORE SUBSTR (STRNC, 1,3 ) +' 0 ' + SUBSTR (STRNG, 4, 9) TO STRNC

ENDIF SUBSTR

STORE SUBSTR (STRNC, 7,2)+SUESTR (STRNC, 1,5) TO STRNG

FIND SSTRNG

CASE SEL ='F'

SET INDEX TD FILE,TITLE, AUTHOR, DATE

FIND SSTRNC

ENDCASE

CLEAR

IF EOF()

Q 10,1 SAY STRNG+' NOT FOUND'

ELSE

DO WHILE CON2

SET COLOR TO ?,1

Q 1,31 SAY 'RECORD NUMBER: '+ STR(RECNO(),5)

SET COLOR TO 7,0

C 3,1 SAY 'TITLE: ' + TITLE

e 5,1 SAY 'AUTHOR: '+ AUTHOR+ORG

? 1 SAY 'TO: '+TO+TO ORG

Q,1 SAY 'DATE: '+DATED+' FILE: ' +EILE_NUM

21,1 SAY 'DESCRIPTION: '+SUESTR(DESCRIP, 1, 64)

12,14 5AY SUASTR(DESCRIP, 65,64)

e 13,14 SAY SUBSTR(DESCRIP, 130,64)

C 14,14 SAY SUESTR (DESCRIP,195,59)

$\begin{array}{llll}\text { C 20,5 SAY'(S)-SKIP } & \text { (E)-EDIT } & \text { (R) -RETURN } & \text { (M) -MAIN MENU }\end{array}$

SET CDLOR TO ?/4

22,10 SAY 'ENTER SELECTION AND (RETURN)'

23,0 SAY'

22,0 SAY .

ACCEPT TO SEL

STORE UPPER(SEL) TO SEL

SET COLOR TO $7 / 0,7 / 1$

* Note: If R,M OR E ARE NOT CHOSEN - ASSUME $S$

IF SEL()'R' AND. SEL()'M' AND. SEL() 'E'

IF ' $=\operatorname{SUBSTR}(S E L, 2,1)$, OR VAL $(S U B S T R(S E L, 2,5))=0$

SKIP 


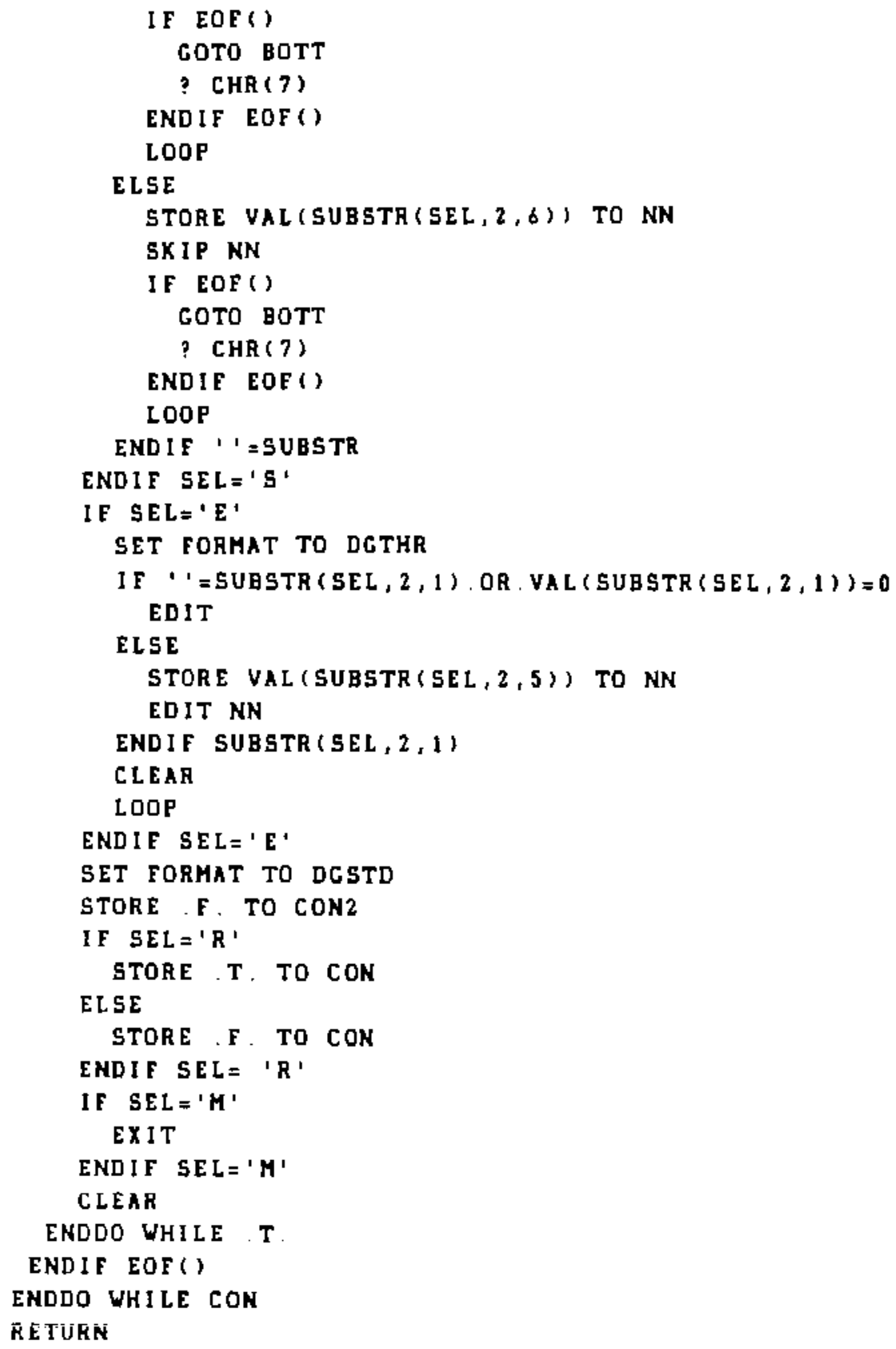




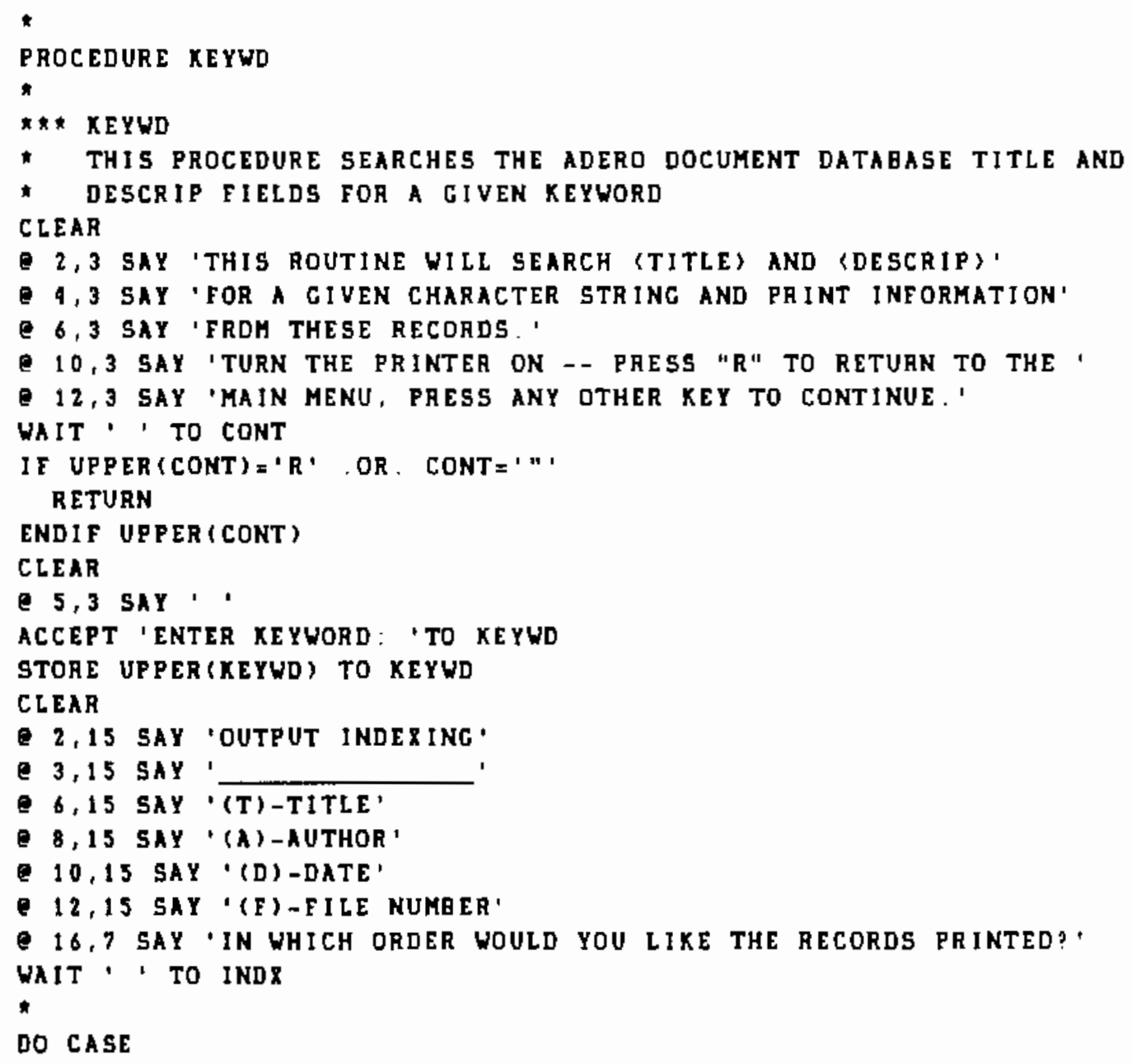




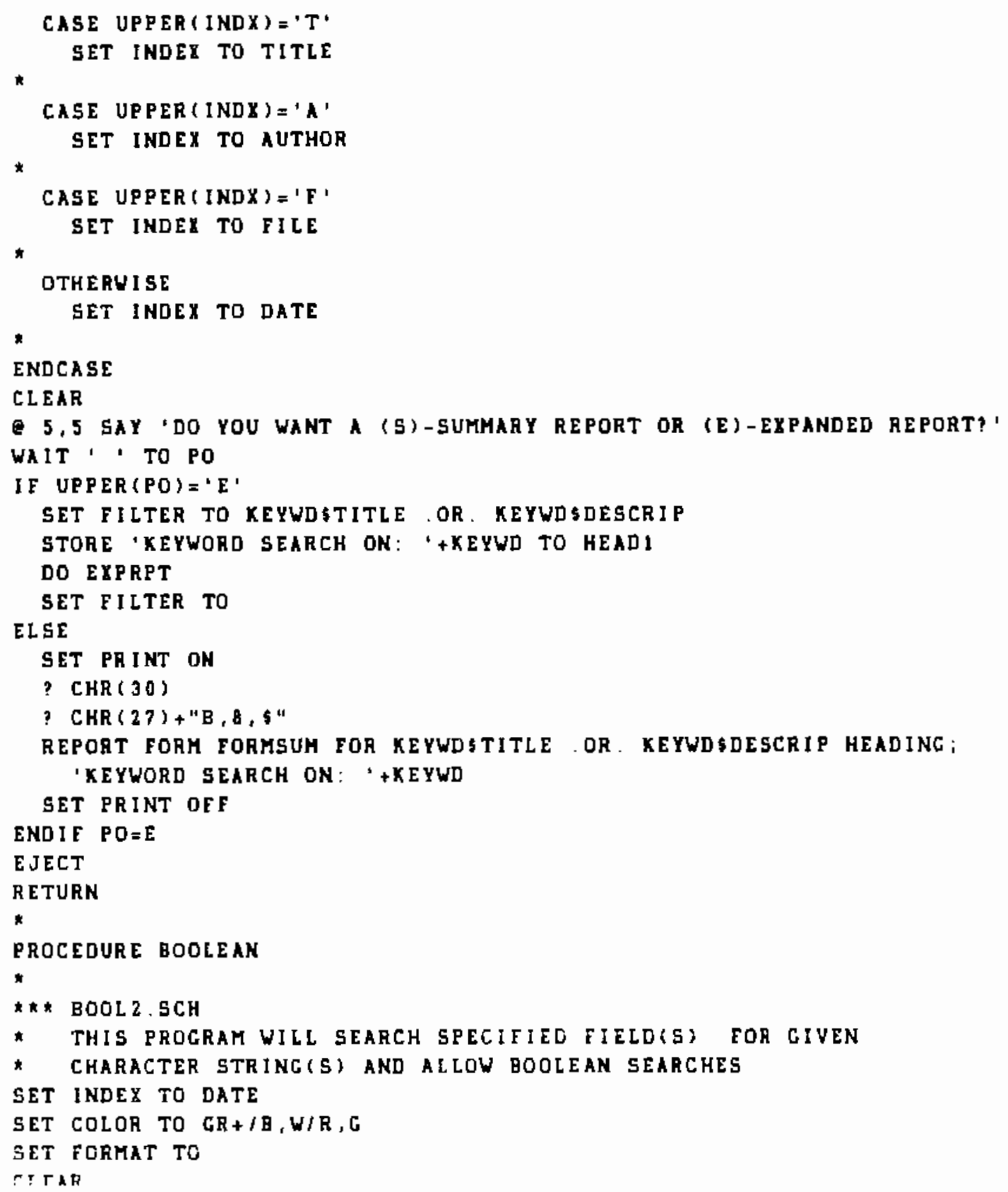




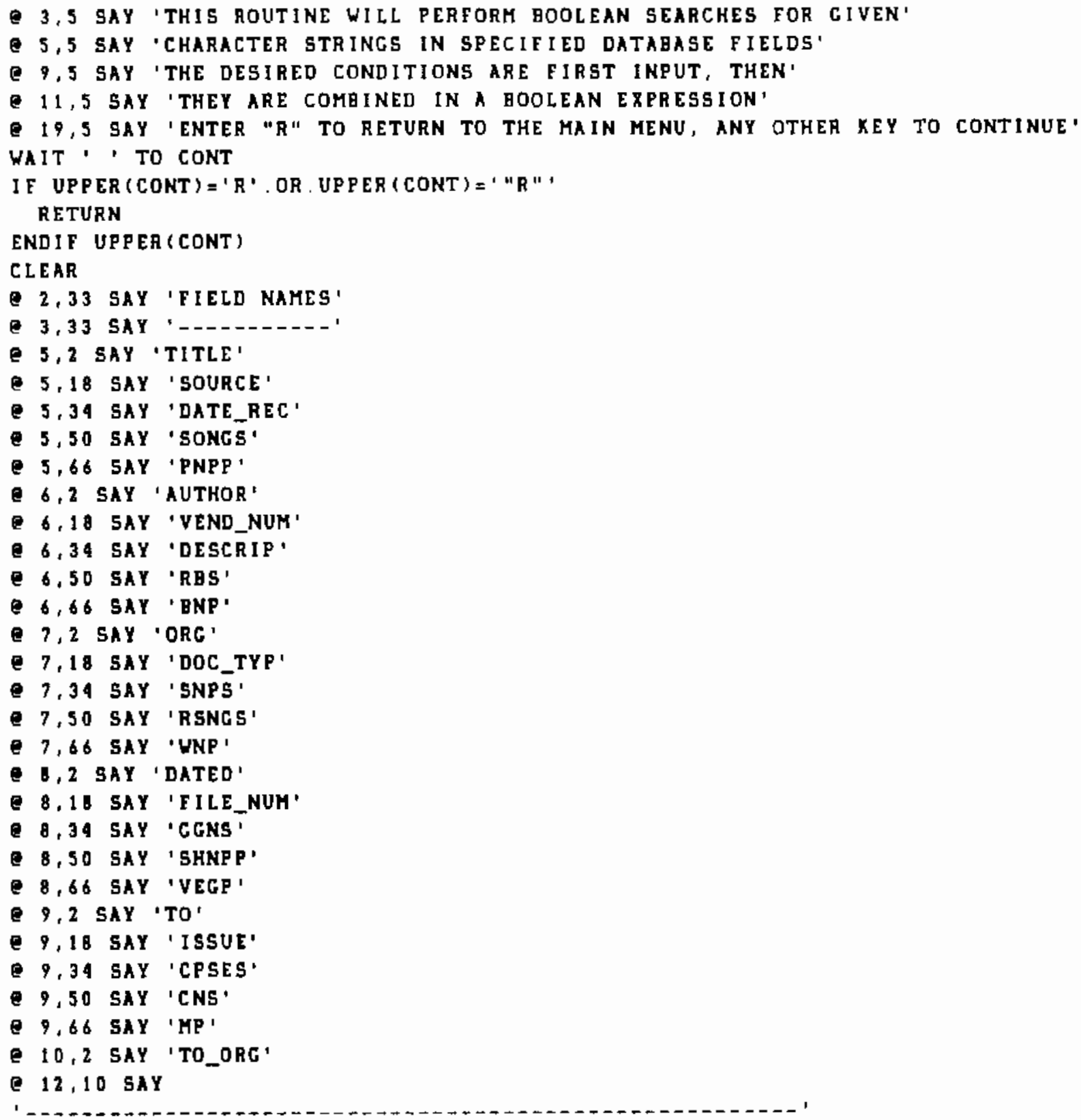




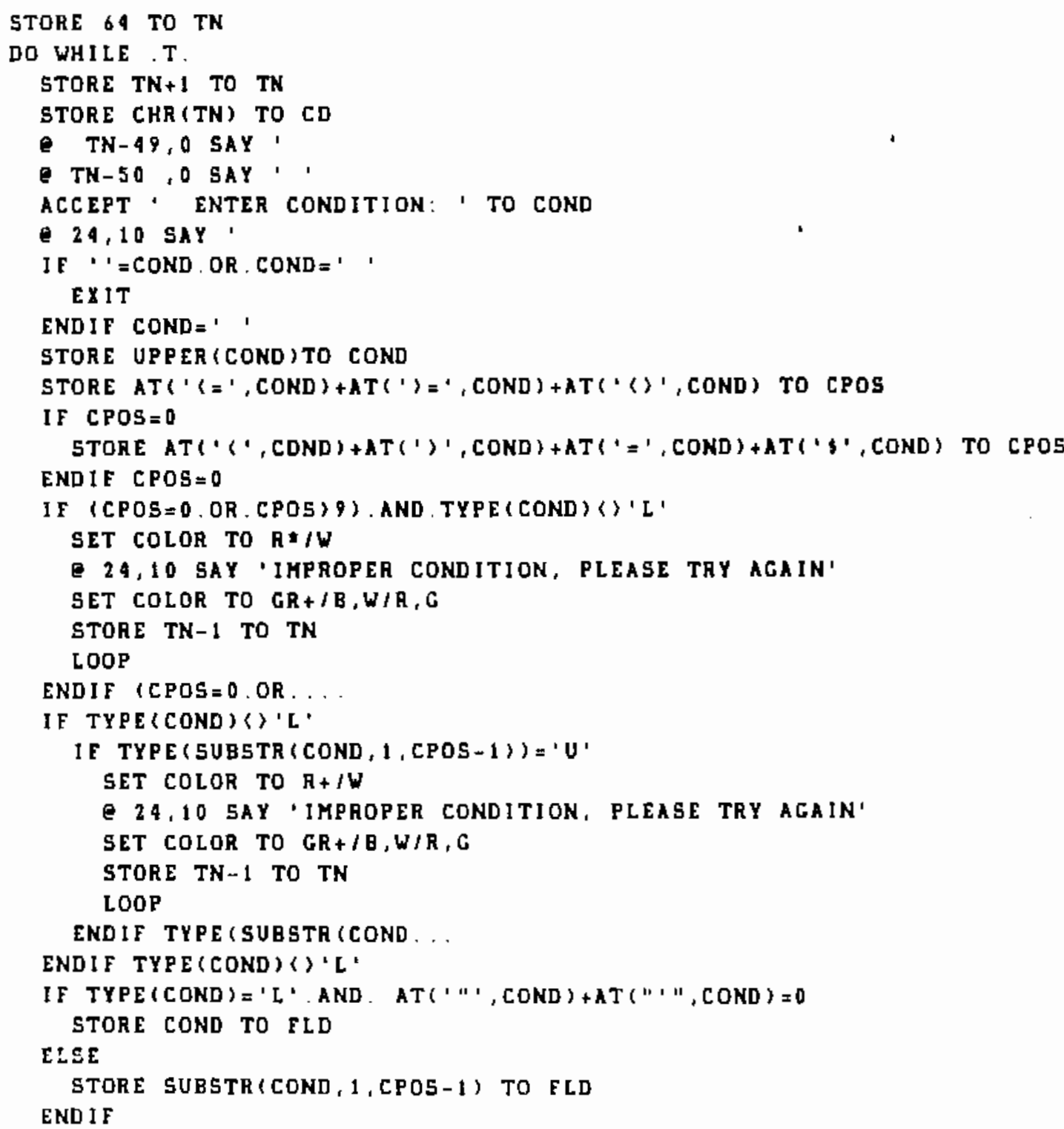




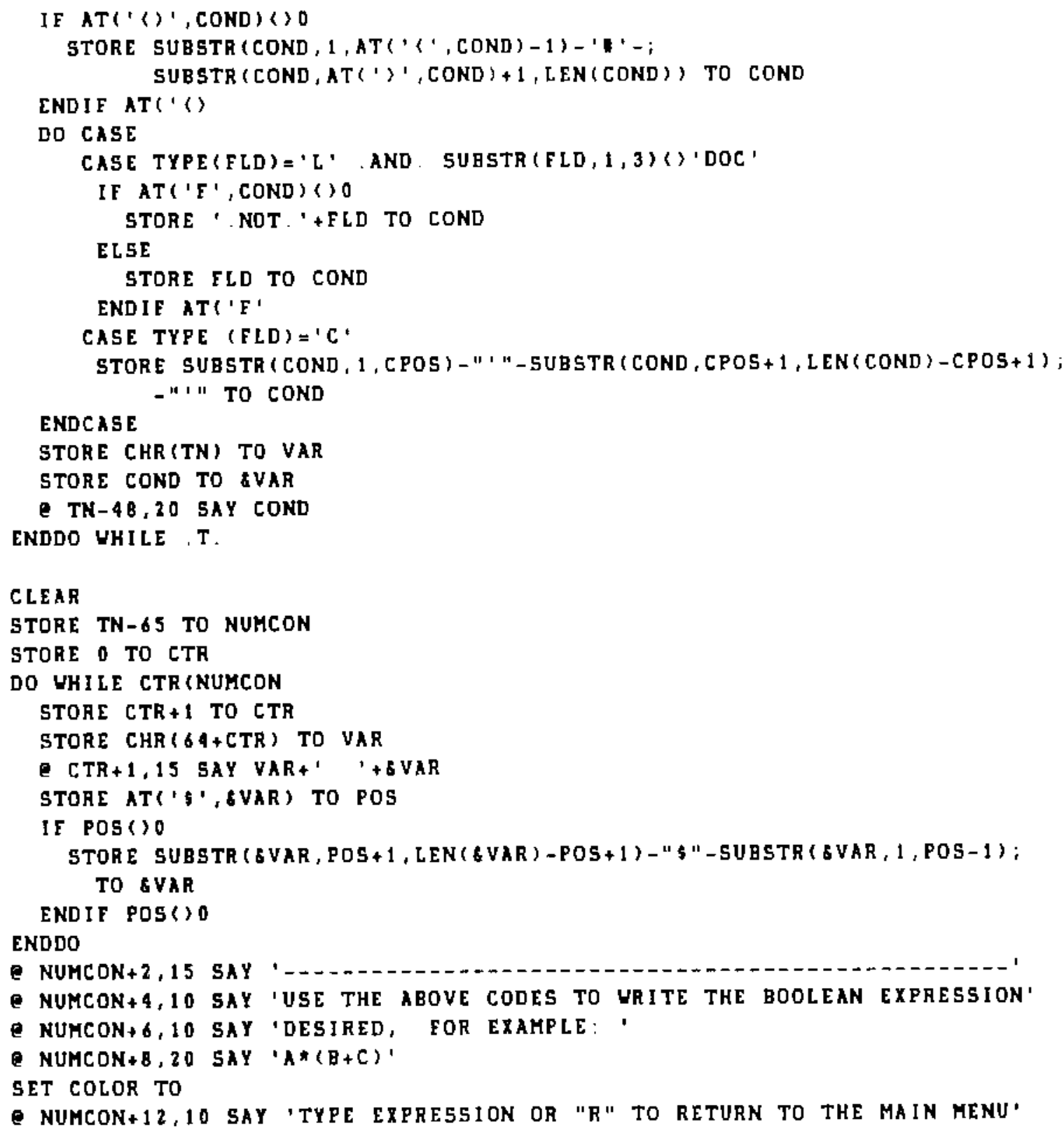




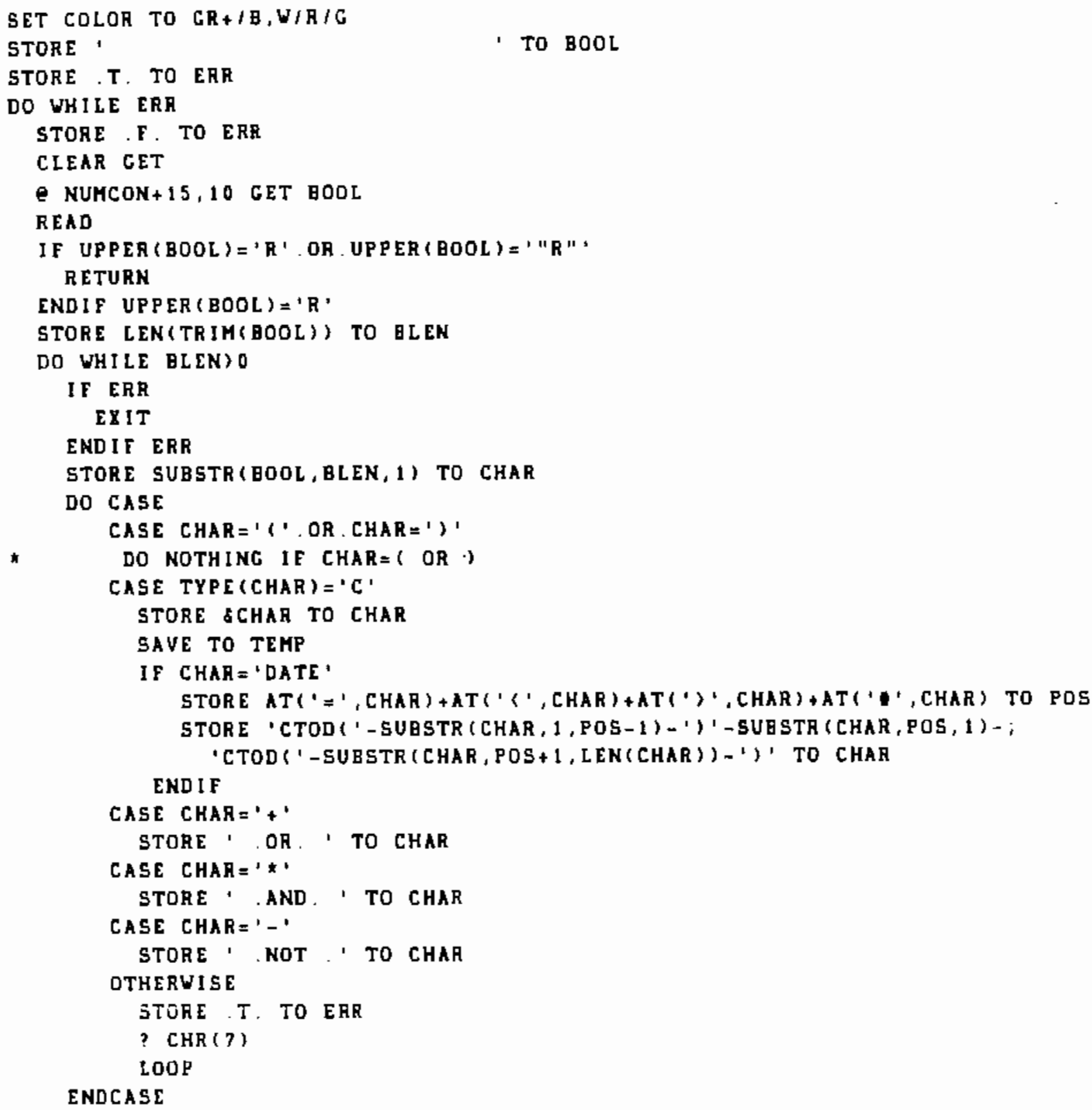


STORE SUBSTR (BOOL , 1, BLEN-1) - CHAR-SUBSTR (BODL, BLEN+1, LEN(BOOL)-BLEN+1);

TO BOOL

STORE BLEN-1 TO BLEN

ENDDO UHILE BLEN)O

ENDDO WHILE ERR

SAVE TO TEMP

CLEAR

Q 3,5 SAY 'DO YOU WANT (S)-SCREEN OR (P)-PRINTER OUTPUT?"

WAIT' 'TO OP

IF UPPER $(O P)=$ 'P

Q 6,5 SAY 'DO YOU WANT (S)-SUMMARY PRINTOUT OR (E)-EXPANDED PRINTOUT?'

WAIT' ' TO PO

IF UPPER $(P O)=$ ' $E$ '

SET FILTER TO 6 BOOL

DO EXPRPT

SET FILTER TO

ELSE

REPORT FORH FORMSUM FOR SBOOL TO PRINT

ENDIF UPPER (PO)

EJECT

ELSE

SET PRINT OFF

DISP OFF SUBSTF(TITLE, 1,70), F ILE_NUM, SUBSTR (TITLE, 71,30), :

END I F

- ' , SUESTR (AUTHOR, 1,36), DATED, ' FOR GBOLL

WhIT

SET FORMAT TO DGSTD

RETURN

PROCEDURE ADDFEC

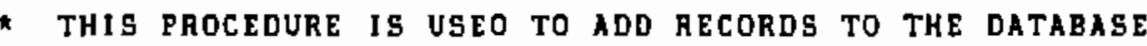

SET HEADINC OFF

SET ESCAPE OFF

CLEAR

STORE ' $Y$ ' TO cont

DO UHILE cont='Y'

APPEND BLANK

SET INDEX TO

GOTO BOTTOM 


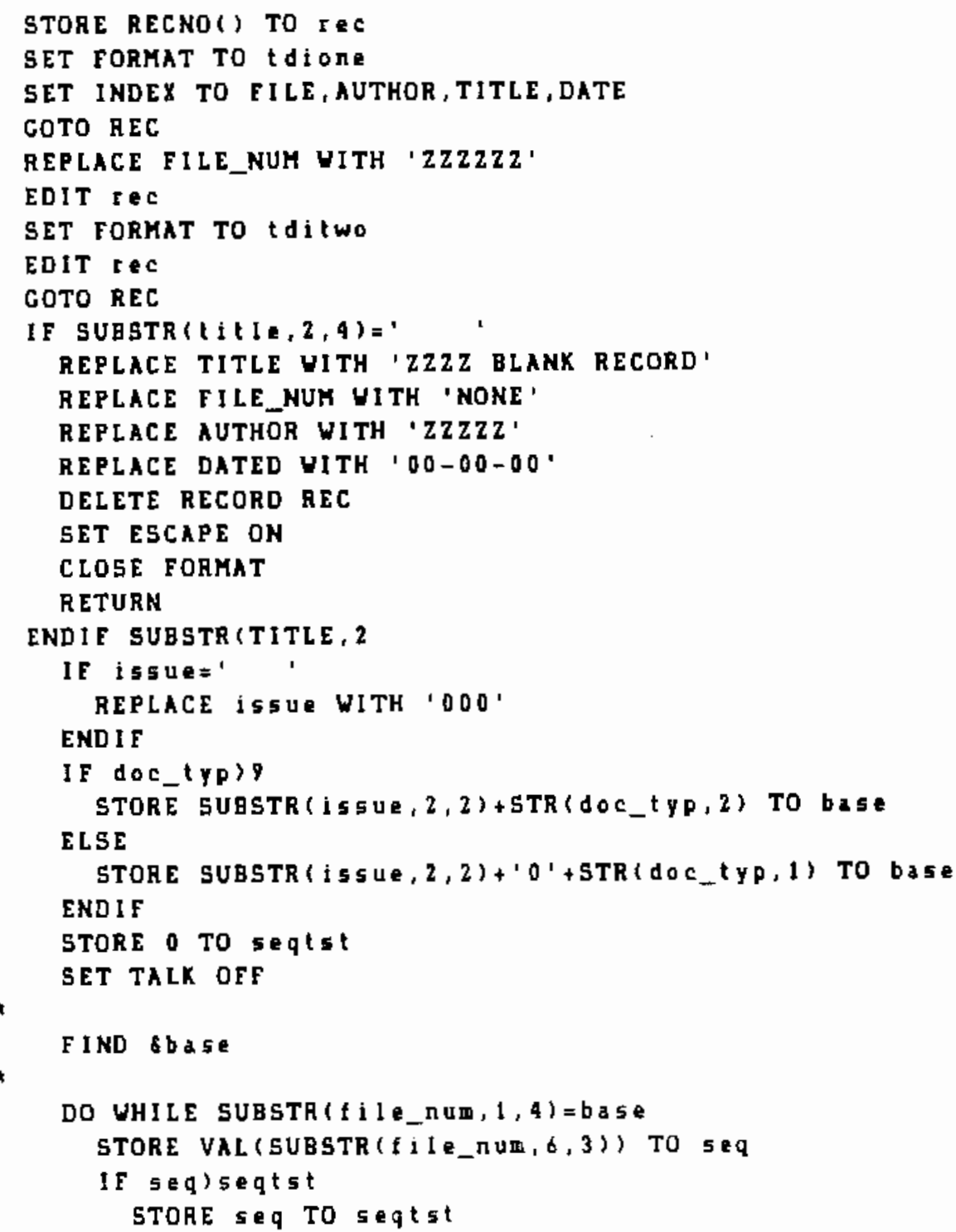


SET ESCAPE ON

RELEASE COUN, SEOTST, BASE, REC, CONT

CLOSE FORMAT

RETUAN

PROCEDURE EDITREC

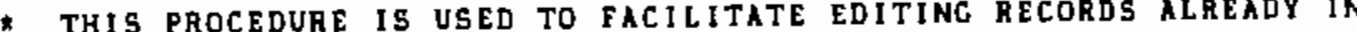

* The datagase ahd allows changes to the file number fields

SET HEADING OFE

CLOSE FORMAT

STORE 'Y' TO coned

DO UHILE UPPER $(\operatorname{con} A)=' Y$ '

CLEAR

21

? 'EILE NUMBER OF FILE TO EDIT? '

?

? "(TYPE "MENU" TO RETURN TO MAIN MENU)'

ACCEPT TO I I I num

IF $f$ i l nUm='MENU' . OR. $f$ i lnUR=' "MENU" .

RETURN

ENDI F

CLEAR

FIND fi inua

IF (EOF() .OR, BOF())

? 'FILE DOES NOT EXIST'

LOOP

\section{END I}

STORE STR(RECNO(), 4) TO IECRUM

STORE $f$ ile_num TO $t 2$

STORE tile num To nile

REPLACE fIIE nUm WITH ' $2 Z Z Z$

SET FOAMAT TO MREOR

EDIT L recnum

GO \& recrum

REPLACE tile_num WITH t 2

IF i $55 \mathrm{U} \&=$ "

REPLACE ISSUE WITH Ũố

E⿺辶ivij $i t$ 


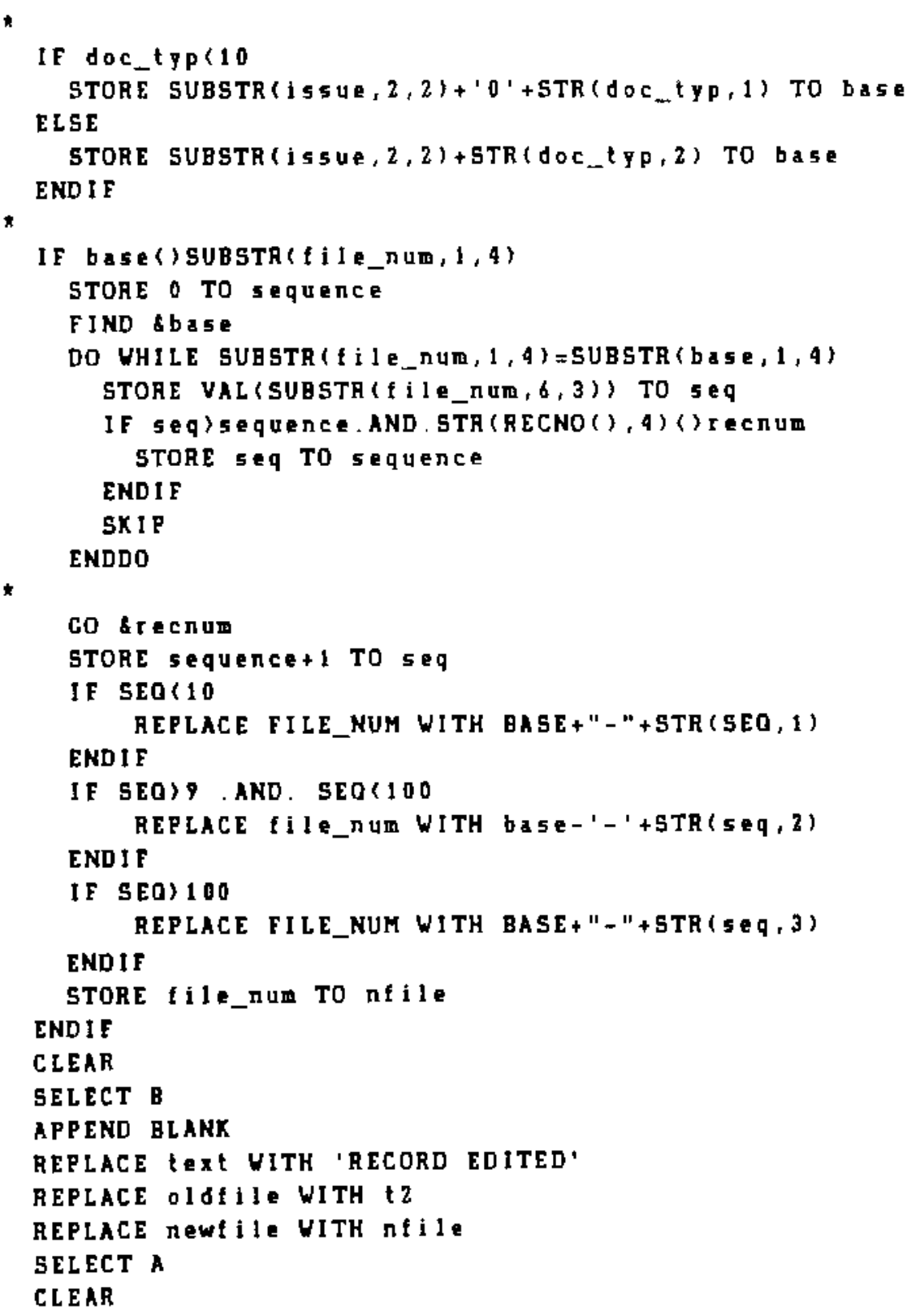




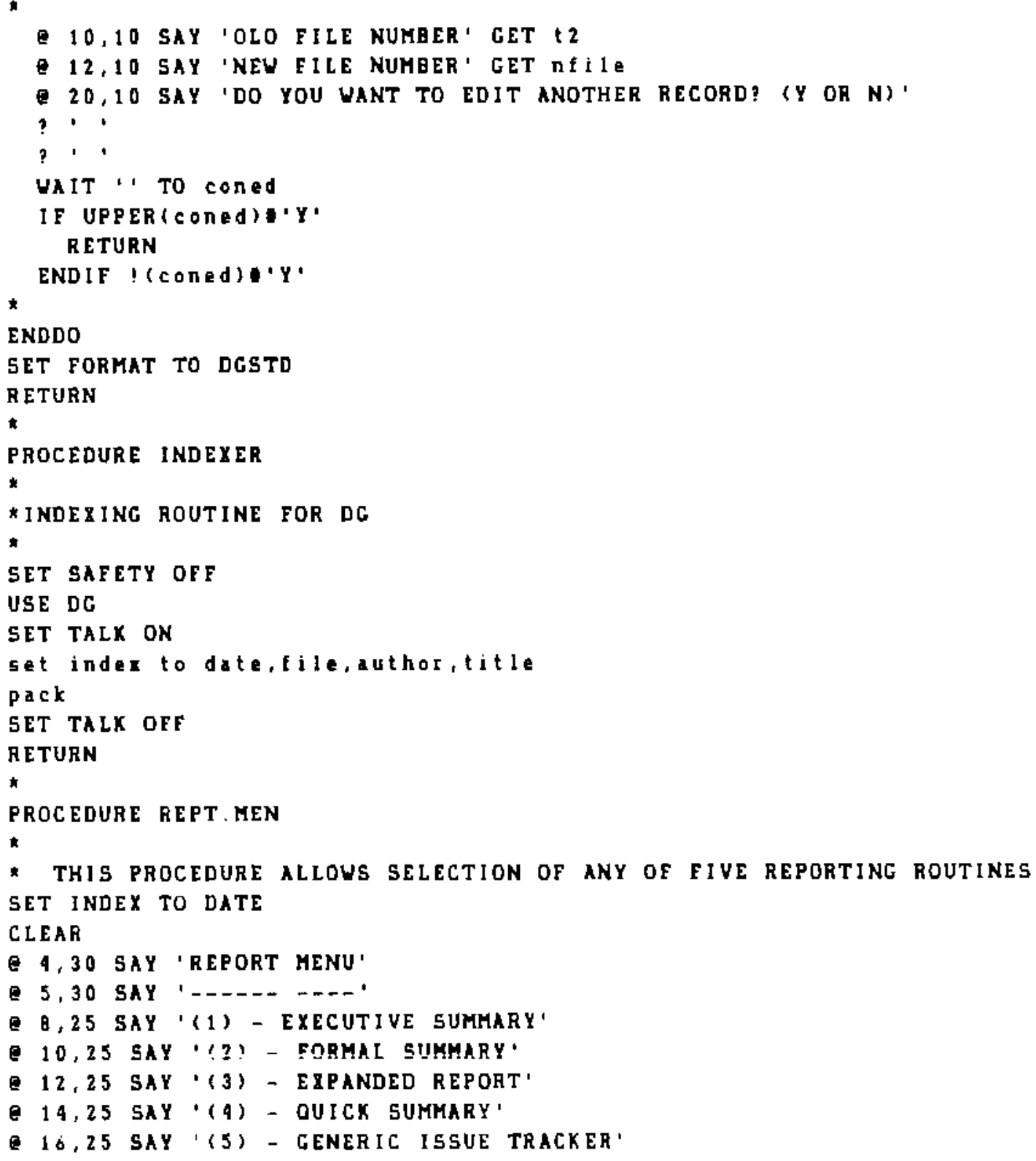


Q 20,5 SAY 'SELECT REPORT FORHAT DESIRED OR TYPE "H" TO RETURN TO MENU'

Q 21,5 SAY 'THEN HIT 〈RETURN〉 TO CONTINUE'

SET FORMAT TO

STORE SPACE ( 25$)$ TO RPT

CLEAR GET

E 23,20 GET RPT

READ

IF UPPER (RPT ) = ' $M$ '

RETURN

ENDIE RPT $=$ ' $\mathrm{H}$

STORE RPT TO COND

IE LEN(TRIH(RPT)) )

IF SUBSTR(COND, 2,1) * '

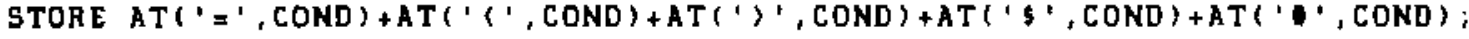
TO POS

I F POS $=0$, OR . POS $=11$, OR. TYPE (SUBSTR (COND, 3, POS-3)) =' $U$ '

SET COLOR TO R*/W

2 23,10 SAY 'IMPROPEA CONDITION

SET COLOR TO GR+/B,W/R,G

WAIT

RETURN

ENDIE POS $=0$

STORE SUESTR(COND, 3, LEN(COND) - 2 ) TO CD

STORE POS-2 TO POS

STORE LEN(TRIH(CD)) -1 TO LL

DO CASE

CASE AT ('S', CD) 10

STORE "'"SUBSTR(CD,POS+1, LL-POS+1)+" 's" TO T

STORE T1+SUBSTR (CD, 1,POS-1) TO CDT

SET FILTER TO \&CDT

CASE SUBSTR $(C D, 1,4)=$ 'DATE'

STORE 'CTOD(DATE'+SUESTR (CD,5,1)+')'+SUBSTR $(C D, 6,1)$ TO T1

STORE T1+"CTOD(" "+SUESTR (CD, 7, L L-6)+" +)" TO CDT

SET FILTER TO GCDT

CASE TYPE(SUESTR $(C D, 1$, POS -1$))=C^{\prime}$ '

STORE SUBSTR(CD, 1, POS) +" " +SUBSTR (CD,POS + 1, L L-POS+1) + " " TO CDT

SAVE TO TEMP

SET FILTER TO \&CDT

CASE TYPE(SUBSTR $(C D, 1, P O S-1))=L^{\prime}$ 


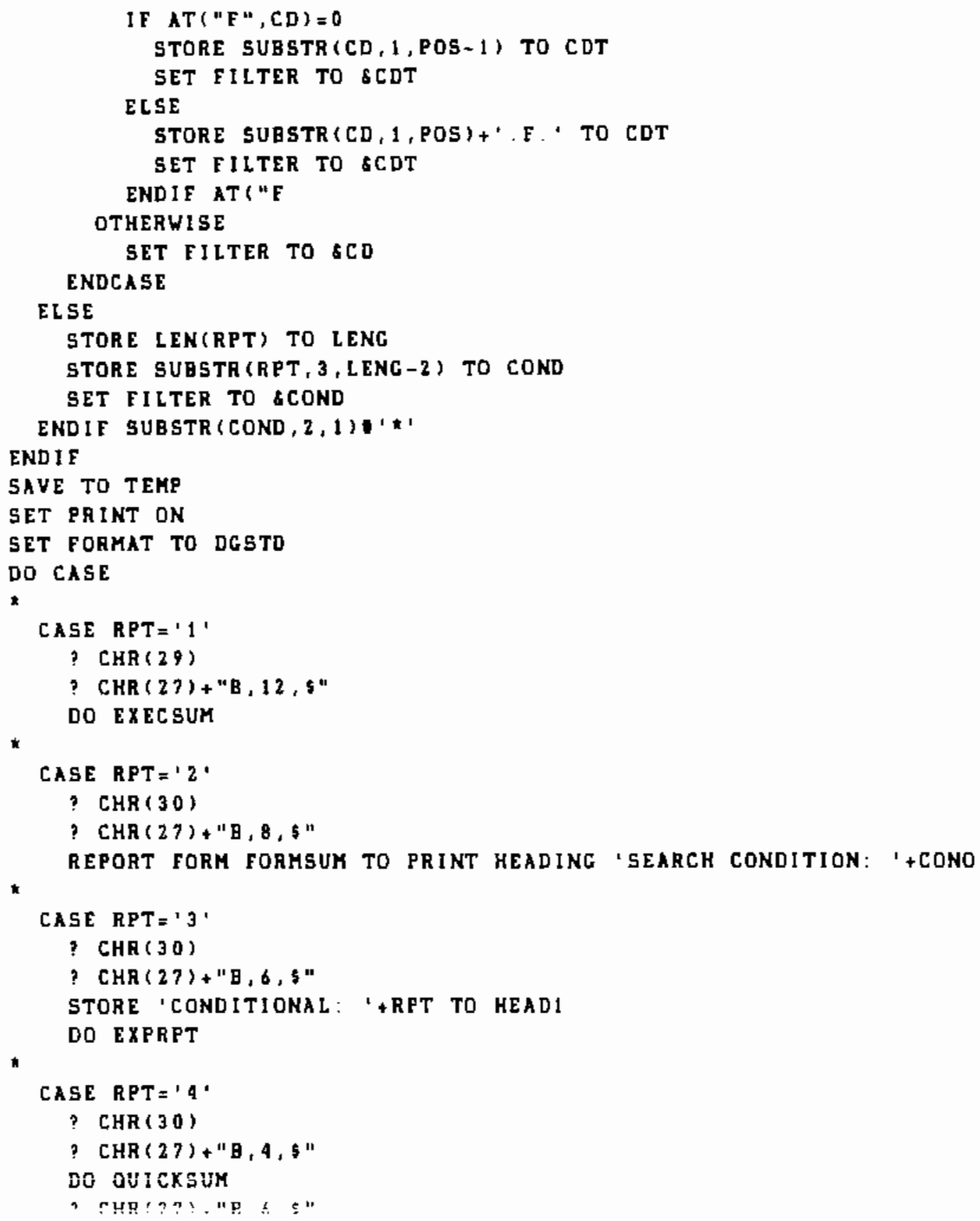




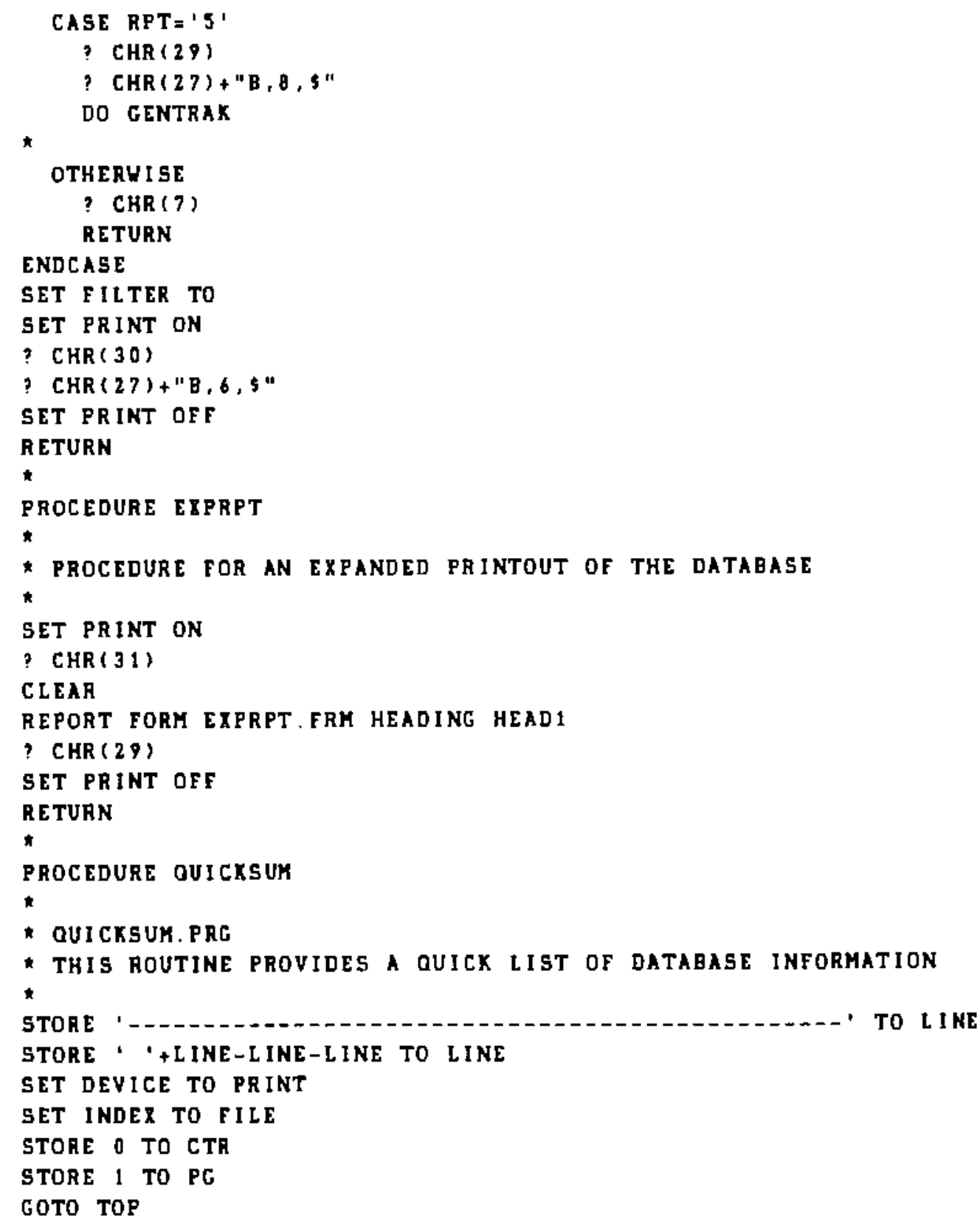




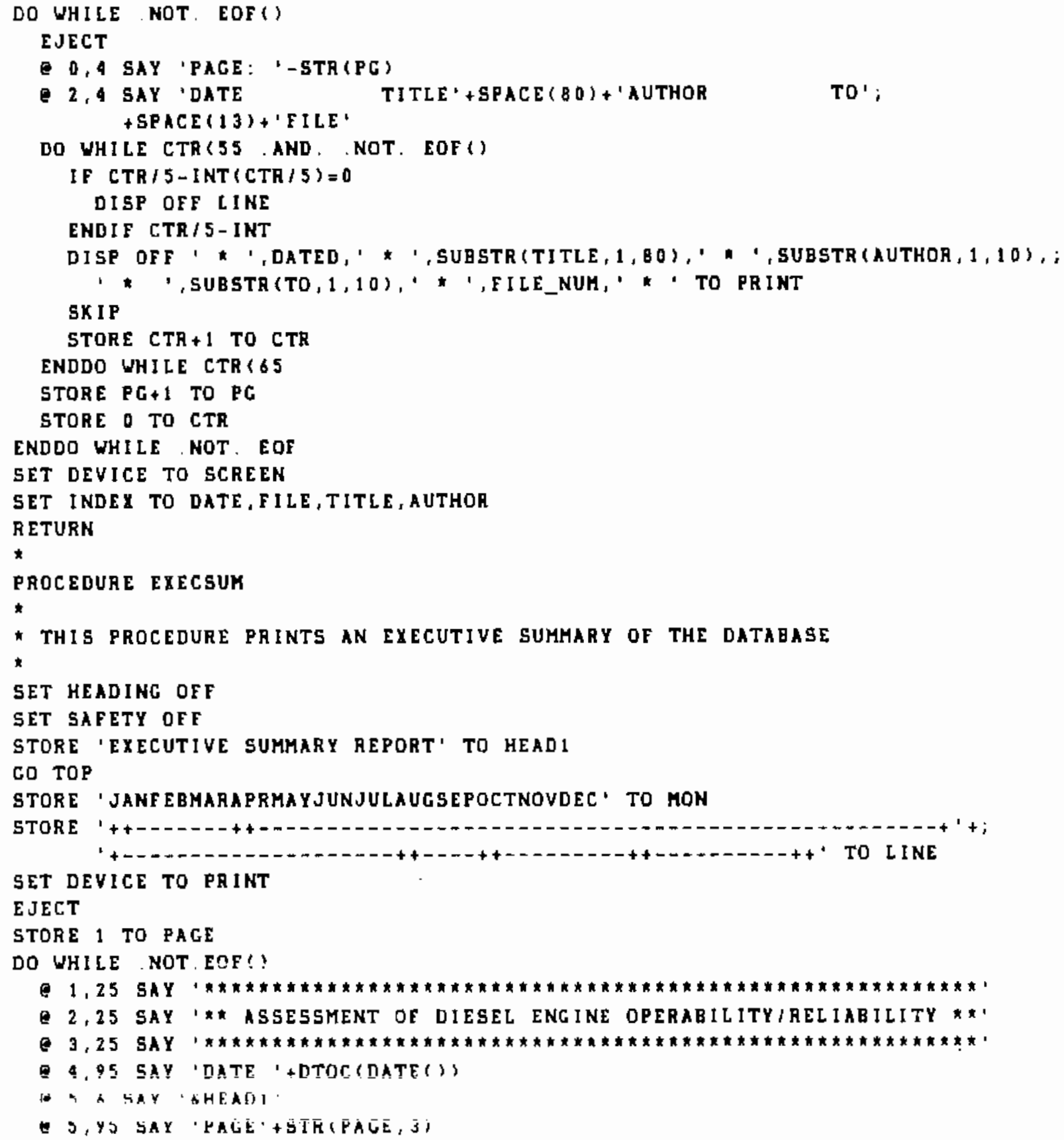




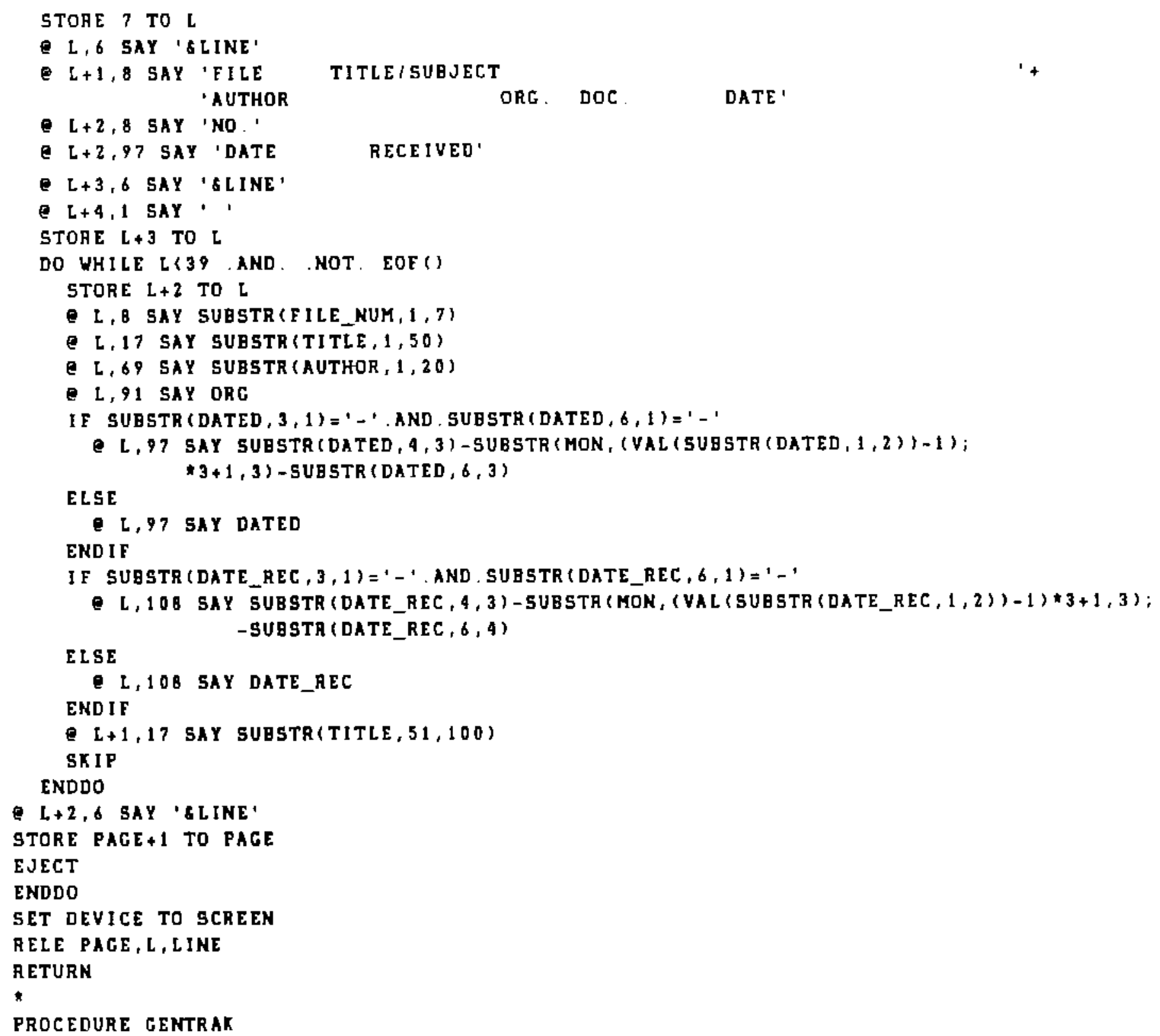


* This procedure is designed to produce a listing of documents pertaining

* TO ISSUES IDENTIEIED as haVING POTENTIAL GENERIC APPLICABILITY

SET HEADING OFF

SET SAFETY OFF

SET DEVICE TO SCREEN

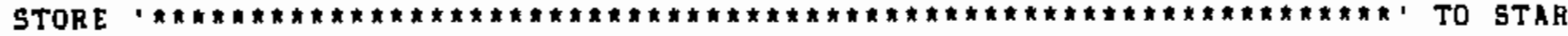

STORE ' ' -

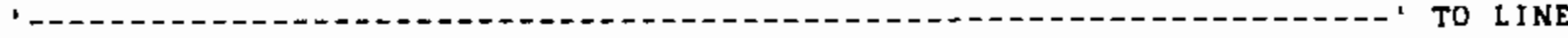

STORE ' $X X X X X X X X X X X X X X X X X X X X X X X X X X X X X X X$ ' TO $X$

STORE 1 TO PACE

SELE B

USE ISSUE

CLEAR

* 5,5 SAY "DEBUg? (Y/N)"

* vait to flac

- If UPPER $(E L A G)=$ ' $y$ ' OR UPPEA $($ OAAG) $=$ ' $T$ ' STORE T. TO FLAC

* ELSE

* store. T. to flag

* endif upper (FLag)

SET DEVICE TO PRINT

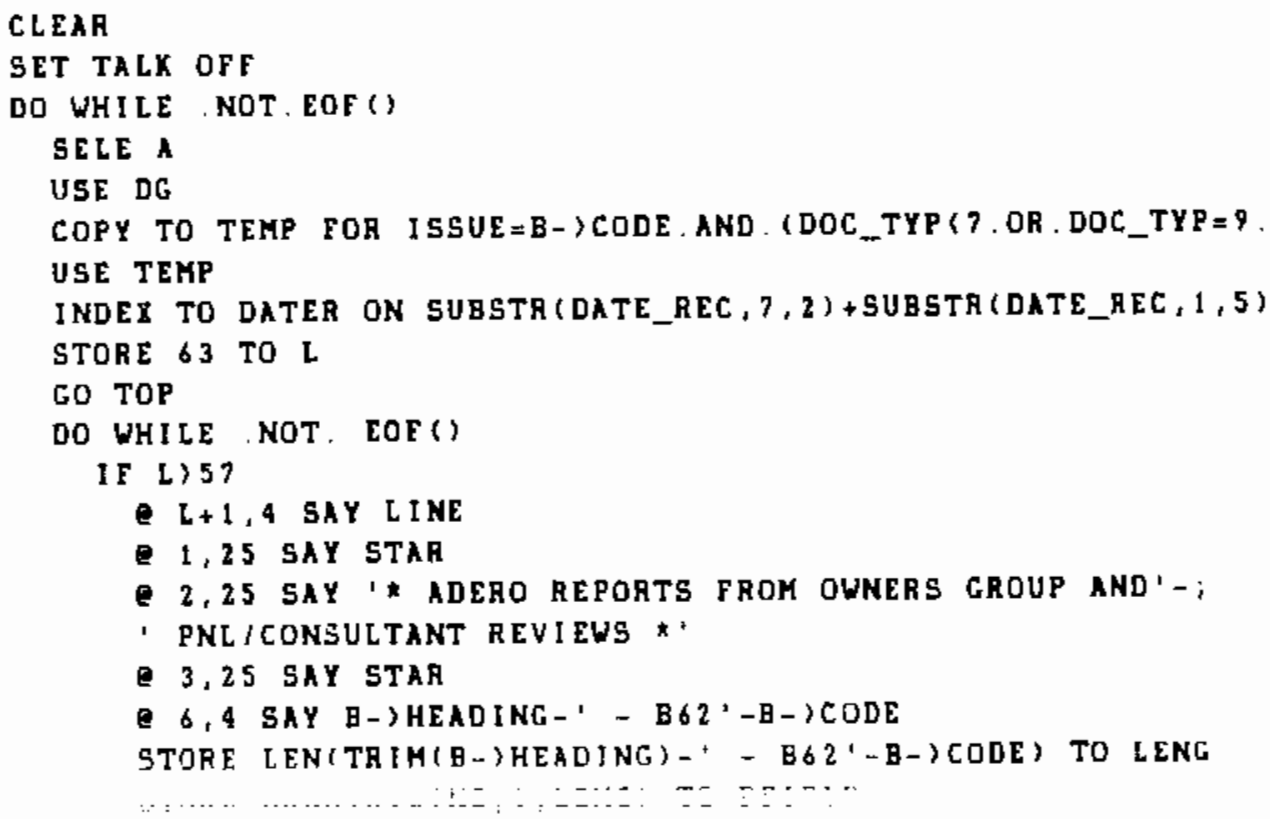




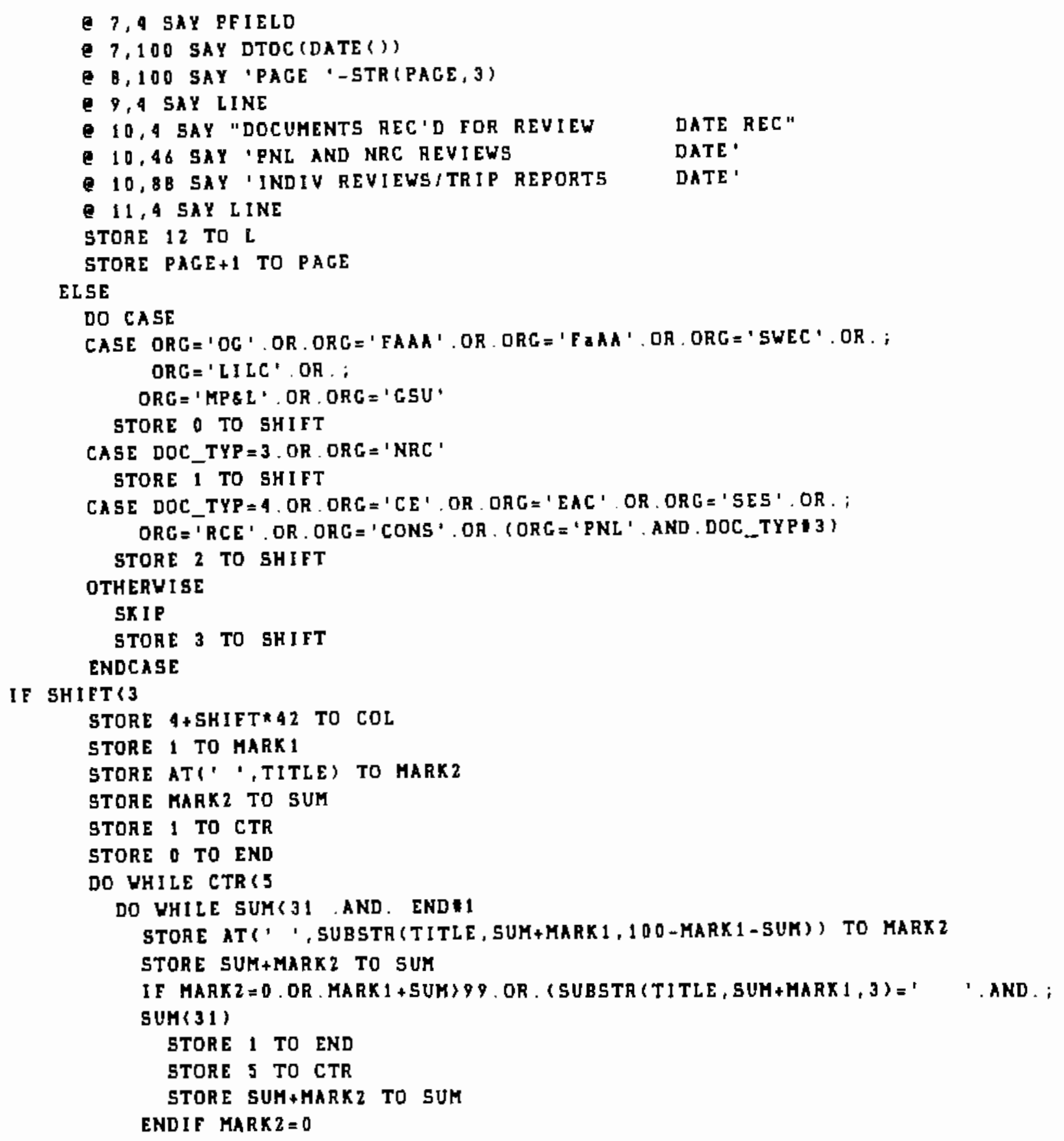




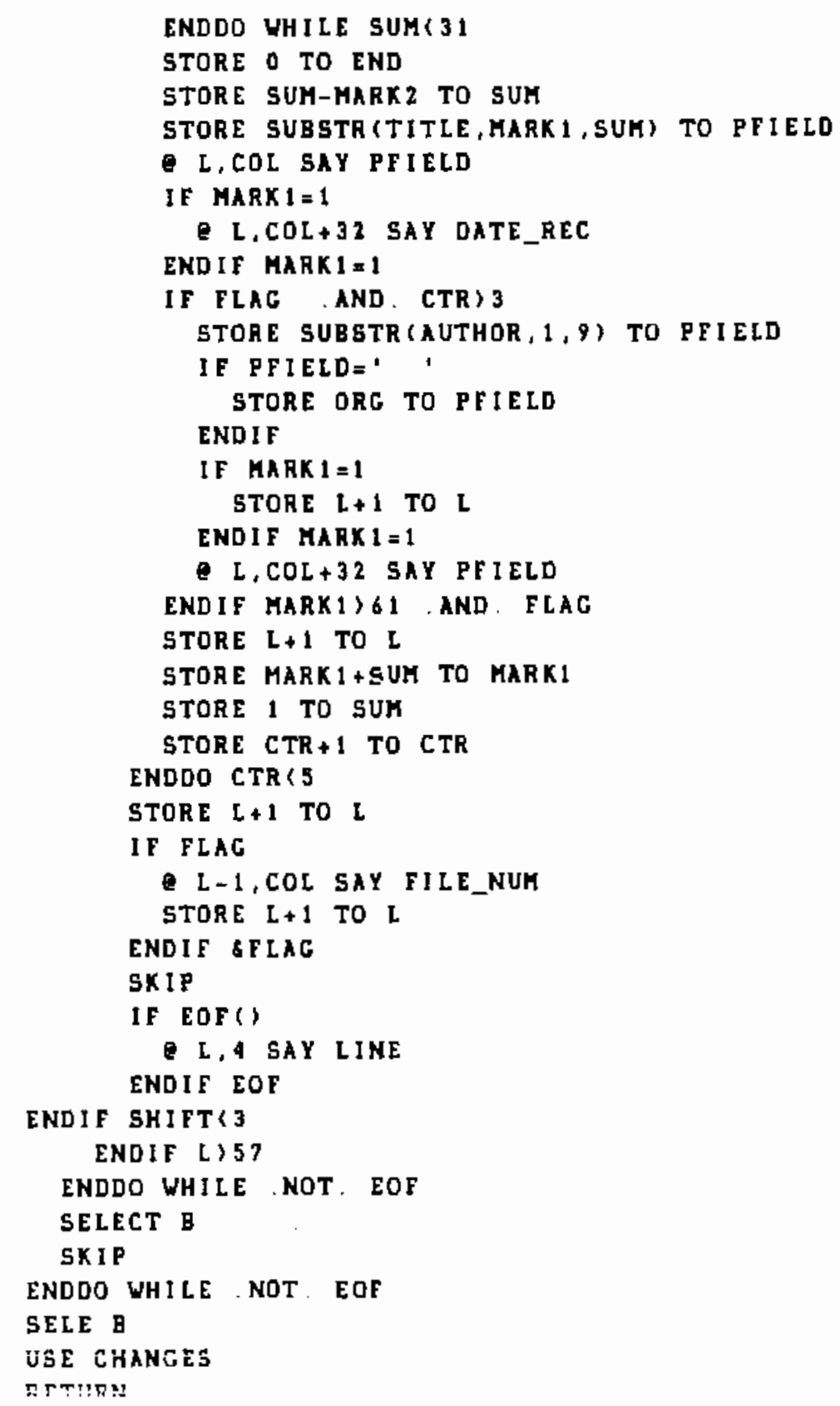




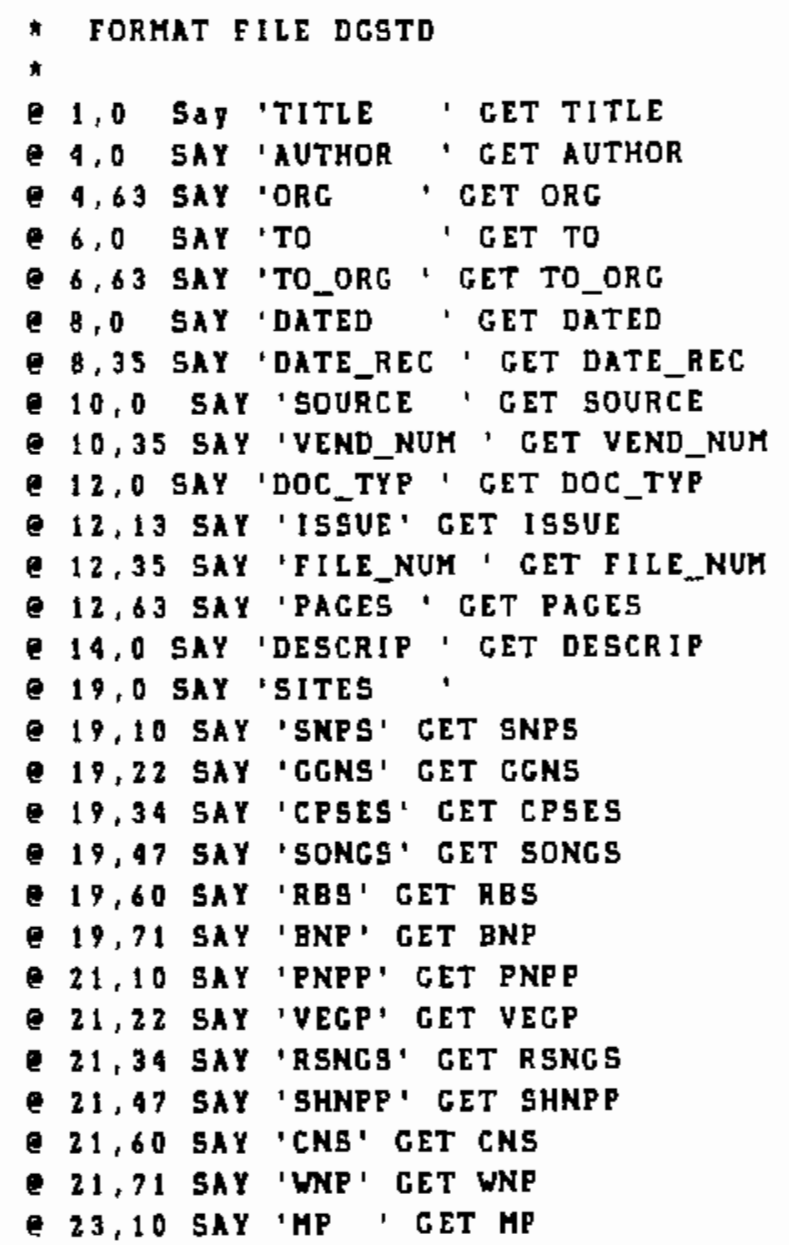




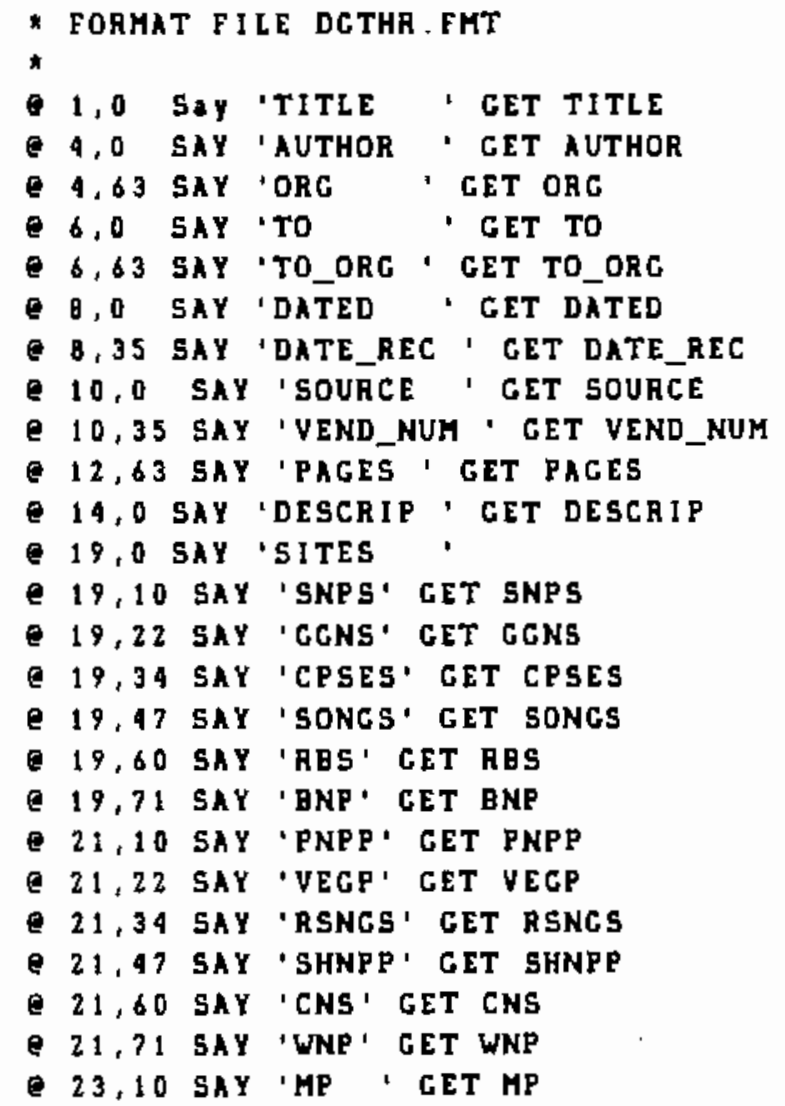




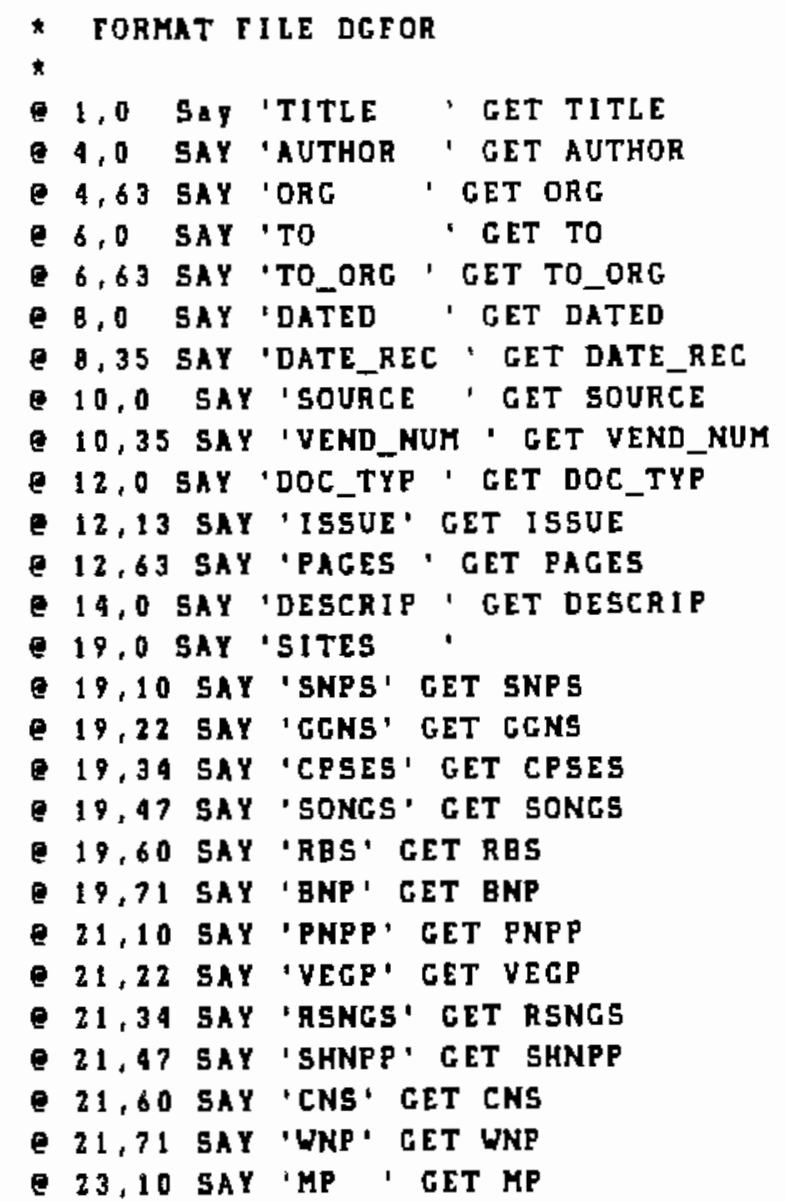


APPENDIX B

LIST OF DOCUMENTS IN THE DOCUMENT DATABASE 



\section{LIST OF DOCUMENTS IN THE DOCUMENT DATABASE}

The documents filed in the document database as of September 30,1985 , are listed on microfiche inserted in the pocket below. 
1

I

I

I

I

I 
APPENDIX C

\section{LIST OF DRAWINGS IN THE DRAWING DATABASE}

The drawings filed in the drawing database as of September 3D, 1985, are listed on microfiche inserted in the pocket below. 

APPENDIX C

\section{LIST OF DRAWINGS IN THE DRAWING DATABASE}

The drawings filed in the drawing database as of September 30, 1985, are listed on microfiche inserted in the pocket below.

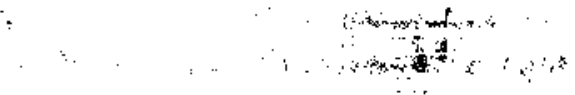

1

C.1 



\section{DISTRIBUTION}

No. of

Copies

OFFSITE

10 C. Berlinger

Division of Licensing

Office of Nuclear Reactor Regulation U.S. Nuclear Regulatory Comission Washington, DC 20555

2 M. Carrington Division of Licensing

Office of Nuclear Reactor Regulation U.S. Nuclear Regulatory Commission Washington, DC 20555

D. Corley

Division of Licensing

office of Nuclear Reactor Regulation U.S. Nuclear Regulatory Commission Washington, DC 20555

\section{F. Miraglia}

Division of Licensing

Office of Nuclear Reactor Regulation

U.S. Nuclear Regulatory Commission

Washington, DC 20555

H. Thompson

Division of Licensing

Office of Nuclear Reactor Regulation

i.s. Nuciedr Keguiatory Commission

Washington, DC 20555
No. of

Copies

M. Williams

Division of Licensing

Office of Nuclear Reactor Regulation

U.S. Nuclear Regulatory Commission

Washington, DC 20555

2 Public Document Room

Division of Technical Information

and Document Control

U.S. Nuclear Regulatory Commission

Washington, DC 20555

\section{ONSITE}

\section{DOE Richland Operations office}
J. J. Sutey

\section{Pacific Northwest Laboratory}
A. Currie
D. Dingee
R. Dodge (15)
R. Lajdler
W. Laity (20)
J. Nesbitt
W. Richmond
L. Schwartz
D. Trent
F. Zaloudek
Technical Information (5)
Publishing Coordination (2) 
